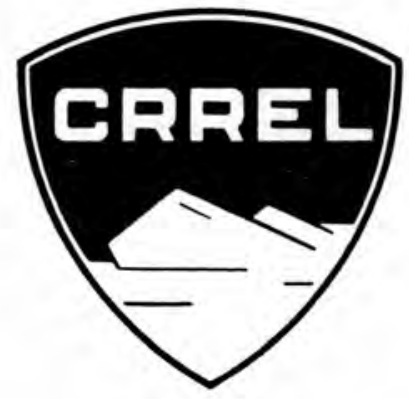

Research Report 188

\title{
SOILS OF THE \\ OKPILAK RIVER REGION, ALASKA
}

by

Jerry Brown

MAY 1966

U.S. ARMY MATERIEL COMMAND

COLD REGIONS RESEARCH \& ENGINEERING LABORATORY HANOVER, NEW HAMPSHIRE

DA Task IV014501B52A02

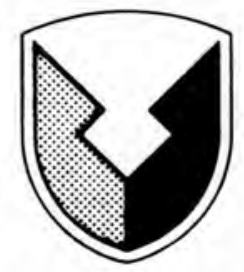

Distribution of this document is unlimited 


\section{PREFACE}

This report was prepared by Dr. Jerry Brown, Earth Sciences Group (Dr. D. M. Anderson, Head), Research Division (Mr. James A. Bender, Chief), U.S. Army Cold Regions Research and Engineering Laboratory (USA CRREL).

These studies were conducted in partial fulfillment of the requirements for the doctoral degree at Rutgers University and were aided by a contract between the Office of Naval Research, Department of the Navy, and the Arctic Institute of North America. Appreciation is extended to Dr. J.C.F. Tedrow for his role as thesis advisor and to Dr. Fiorenzo Ugolini, Dr. Edward G. Sable, Dr. John E: Cantlon, and Dr. William Malcolm for their assistance in the field. Field support was provided by the Arctic Research Laboratory, Max E. Brewer, Director.

USA CRREL is an Army Materiel Command laboratory. 
Preface-1..

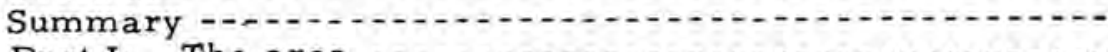

Part I: The area

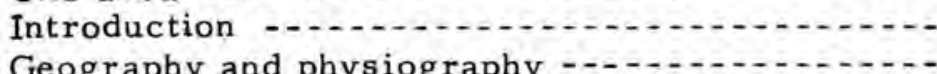

Geography and physiography

Glacial and bedrock geology Vegetation

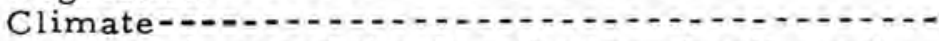

Part II: Cryopedology and the distribution of soils and surface features

Manifestation of frost action in soil -................

Types and distribution of soils and surface features

Page

ii

vi

1

1

1

4

4

5

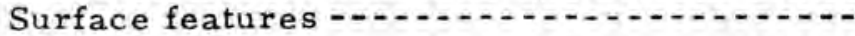

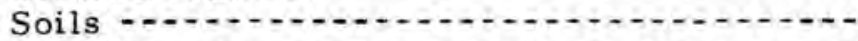

Part III: Soil-forming processes $\ldots \ldots+\ldots$

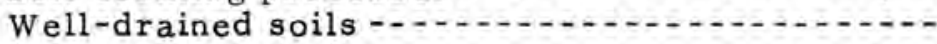

An organic terrain

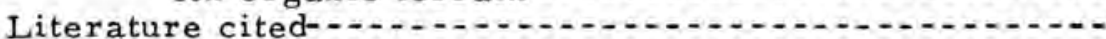

\section{ILLUSTRATIONS}

Figure

1. Topographic and index map of the Okpilak River

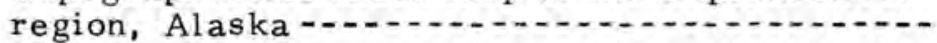

2. Aerial oblique photograph looking south onto the Okpilak River Valley and the adjacent uplands and mountains -........................................

3. Solifluction slope of the unglaciated uplands -.--

4. Soil of the solifluction slope with characteristic buried organic layer above the frost table -.-.--

5. Cross section through the frontal portion of a

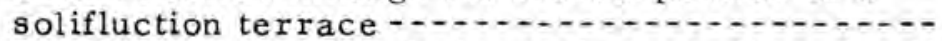

6. Cross section through the upslope portion of solifluction terrace (Fig. 5).

7. Thawed soil adjacent to a frost scar mound $\left(\mathrm{S}_{\mathrm{M}}, \mathrm{Fig}\right.$. 32). 10

8. Thawed soil in the center of the frost scar mound

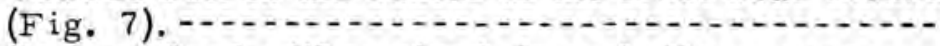

9. Base of dead willow shrub in a shallow, seasonally thawed organic layer -..............................

10. Top of present-day frost table from which dead willow was removed (Fig. 9)

11. Flow of gravelly soil resulting in the burial of

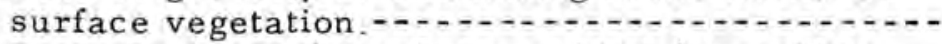

12. Buried surface (top of shovel blade) in cobbly

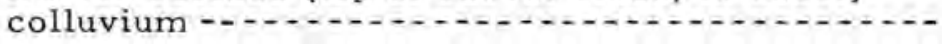

13. Sorted gravels in the trough of a stone net..... 


\section{CONTENTS (Cont'd)}

Figure

14. Pavement of slaty rock fragments devoid

Page

of fines -

15. Turned-under peat adjacent to weakly developed peat ring ( $\mathrm{R}_{\mathrm{P}}$, Fig. 29)

16. Opposite side of same peat ring, but with pocket of sorted gravel instead of buried peat lobe :-..-

17. Large ice wedge in peaty deposit -..............

18. Variations in surface features and soil morphology as a result of frost action

19. Relatively dry moraine complex with numerous sorted and nonsorted features-........... 18

20. Sorted nets on lateral moraine $\left(\mathrm{N}_{\mathrm{T}}\right) \ldots \ldots . . . . .21$

21. Sorted nets on flat bedrock terrace $\left.\mathrm{N}_{B}\right) \ldots 21$

22. Nonsorted, stone-centered nets (INSN) -...... 21

23. Nonsorted, stone-centered nets on slope (NSS)- 21

24. Nonsorted nets, polygonal intergrade (NP) -..- 22

25. Sorted polygon (PS) 22

26. Nonsorted, ice-wedge polygons $\left(W_{N}\right) \ldots \ldots . . .-22$

27 Nonsorted, ice-wedge polygons on slope $\left(W_{S}\right)$, -

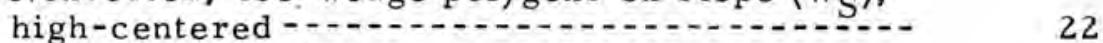

28. Sorted circles $\left(\mathrm{S}_{\mathrm{C}}\right)$

29. Nonsorted circle, with raised peat ring ( $R$

30. Nonsorted circle, with raised peat ring $\left(\mathrm{R}_{\mathrm{P}}\right) \ldots$

30. Nonsorted circle, frost scars $\left(S_{F}\right)$

31. Nonsorted circle, frost scars on slope ( $S_{F S}$ ) -- 23

32. Nonsorted circle, frost scar mound on slope $\left(\mathrm{S}_{\mathrm{M}}\right)$

33. Nonsorted circle, inundated mounds $\left(\mathrm{M}_{\mathrm{I}}\right) \cdots \cdots$

34. Nonsorted step $\left(\mathrm{S}_{\mathrm{N}}\right)$

35. Nonsorted stripes $\left(\mathrm{S}_{\mathrm{S}}\right) \ldots$

36. Solifluction terraces and mounds $\left(\mathrm{S}_{\mathrm{T}}\right)$

37. Hummocks, moss $\left(\mathrm{H}_{\mathrm{M}}\right)$

38. Hummocks, peaty mounds $\left(\mathrm{H}_{\mathrm{P}}\right)$

40. Frost heave, silt ooze $\left(\mathrm{H}_{\mathrm{S}}\right)-\ldots$

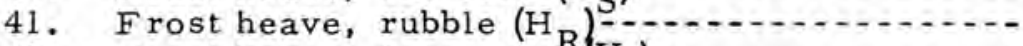

42. Frost heave, ice mound $\left(\mathrm{H}_{\mathrm{I}}\right) \div$

43. Rock debris benches $\left(D_{B}\right)$

44. Rubble pit (P)

45. Mudflow $\left(\mathrm{M}_{\mathrm{F}}\right)$

46. Rock slides $\left(\mathrm{M}_{\mathrm{S}}\right)$

47. Strangmoor or peat ridge $\left(\mathrm{S}_{\mathrm{G}}\right) \ldots$

48. Levees (L) $\quad$ Trails (T)

50. Mat on bedrock (11)

51. Mat on rubble (11)

52. Mat on well-drained substratum, regosol inter-

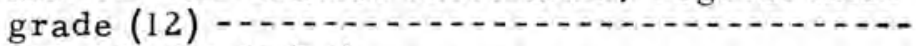


CONTENTS (Cont'd)

Figure Page

54. Lithosol on bedrock (20) 32

55. Shallow arctic brown on bedrock (21) 32

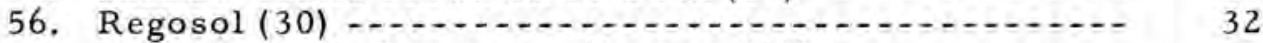

57. Shallow arctic brown on alluvium (31)

58. Podzol-like soil on till (32)

59. Arctic brown mull (41) -......................... 33

60. Raw tundra with vesicular structure (50) 33

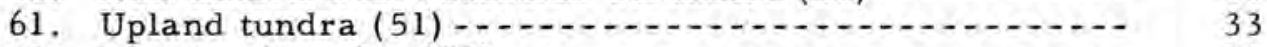

62. Inundated tundra (52)

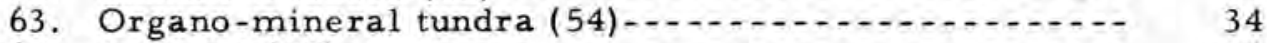

64. Sod peat $(70) \ldots 34$

65. Moss peat (71)

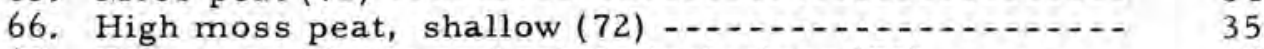

67. Dry peat with ice and cobble inclusions (73) $\ldots \ldots . . .35$

68. Bog peat along river terrace (74) ......... 35

69. Map of soils and patterned ground in the vicinity of the

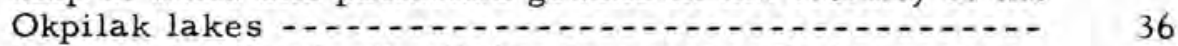

70. Decreasing depth of soil development with increasing
altitude in the Brooks Range (Tedrow and Brown, 1962) 40

71. Weakly developed ice-wedge polygons with small cottongrass tussocks (moss peat) - ........... 42

72. Mosaic of polygon tops (dry peat) and troughs (sod peat) 42

73. Area of peaty mounds which possibly represents final degradation of polygonal area

74. Characteristic moss-peat vegetation with both tussocks

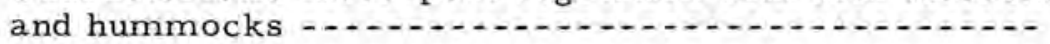

\section{TABLES}

Table

I. Comparative summer climatic data for Barrow, Barter Island, and Anaktuvuk Pass (1957-1961) -...........

II. Particle-size distribution (\%) of two soils exhibiting

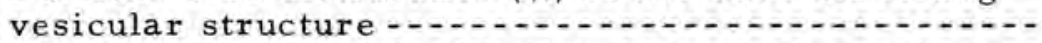

III. Mapping legend for the Okpilak River region, Alaska -

IV. Occurrence of soils with surface features ..........

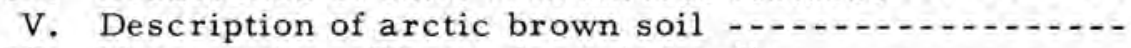

VI, Moss peat profiles and related soils -................

VII. Partial chemical data from a moss peat and related

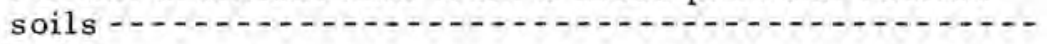




\section{SUMMARY}

Concepts of arctic pedology are applied to the glaciated and unglaciated terrains in the vicinity of the Okpilak River, northeastern Alaska $\left(69^{\circ} 25^{\prime} \mathrm{N}, 144^{\circ} 00^{\prime} \mathrm{W}\right)$. The manifestations of frost action in arctic soils are considered under two general forms: 1) the surficial configurations or patterned ground and 2) the morphological characteristics of the seasonally thawed soil and the upper zone of perennially frozen ground. Approximately 55 types of soil conditions and surface features are described and mapped in an area encompassing both the northern Brooks Range and the southern Foothill Provinces. These include the genetic soils of arctic Alaska, numerous soil conditions, and many of the common sorted and nonsorted circles, nets, polygons, steps, and stripes. In both the glaciated and periglacial areas sorted features predominate on the coarse-textured substrata.

The arctic brown soils are distributed on the well-drained sites along valley (longitudinal) traverses and across mountain (altitudinal) gradients. On a sequence of valley moraines, acid parent material is considered more important than time and mesoenvironments in influencing the depth and development of the characteristic brown solum. Weakening of the soil-forming processes with increasing altitude is suggested in the mountains. In the valleys, a podzol-like soil is observed in close proximity to the arctic brown soils and in association with acid parent materials, dwarf birchheath vegetation and protected microrelief positions. A combination of peaty soils associated with ice-wedge polygons constitutes an organic terrain. The developments of these soils under the arctic environment are discussed. 
by

Jerry Brown

PART I. THE AREA

Introduction

The soils of northern Alaska have been under investigation since the early 1950's. The major genetic soils and the processes of soil formation have been recognized and described (Tedrow and Hill, 1955; Drew and Tedrow, 1957; Tedrow et al., 1958; Douglas and Tedrow, 1961; Hill and Tedrow, 1961; Tedrow and Brown, 1962; Ugolini and Tèdrow, 1963; Brown and Tedrow, 1964). The relationships of these arctic soils to patterned ground and the cold environment are well documented, particularly for the Coastal Plain and Foothill Provinces (Drew and Tedrow, 1962; Tedrow and Cantlon, 1958).

In the Okpilak River region of northeastern Alaska, patterned ground, unstable soil surfaces, and a diversity of genetic and nongenetic soils result in a degree of soil complexity greater than is found on either the northern Foothills or Coastal Plain. The presence of altidudinal and longitudinalvalley gradients in the mountains and foothills provides an opportunity to evaluate the relative importance of several factors of soil formation. This paper summarizes the results of investigations which were designed to provide information on soil genesis, morphology, and distribution in an area for which virtually no previous soils knowledge existed (Brown, 1962b).

\section{Geography and physiography}

The study area lies within the region described by Leffingwell in his monumental and inspiring investigations of the Canning River region (1919). For present purposes, the Okpilak River region is delineated as the area between the west bank of the Jago River and the east bank of the Hulahula. River, a distance of some $25 \mathrm{~km}$. The southern portion begins at the upper fork of the Okpilak River, $25 \mathrm{~km}$ south of the mountain front. The northern limit extends about $20 \mathrm{~km}$ beyond the mountain front. The area lies within the Mt. Michelson and Demarcation Point quadrangles (approximately 69 $15^{\prime}$ to $69^{\circ} 35^{\prime} \mathrm{N}, 143^{\circ} 45^{\prime}$ to $144^{\circ} 30^{\prime} \mathrm{W}$ ) (Fig. 1). Additional observations were made in the vicinity of Lakes Peters and Schrader $\left(69^{\circ} 20^{\prime} \mathrm{N}, 145^{\circ} 00^{\prime} \mathrm{W}\right)$, Anaktuvuk Pass $\left(68^{\circ} 05^{\prime} \mathrm{N}, 151^{\circ} 30^{\circ} \mathrm{W}\right)$ and Porcupine Lake $\left(68^{\circ} 45^{\prime} \mathrm{N}, 146^{\circ} 30^{\prime} \mathrm{W}\right)$ to supplement the soil studies in the Okpilak River region.

The Okpilak River is headed by two valley glaciers located in the Romanzof Mountains of the northeastern Brooks Range. Their streams join to form the Okpilak River which then cuts a 3 to 12 meter deep postglacial canyon for a distance of some $7 \mathrm{~km}$. The river flows through a wide $U$-shaped glacial trough past the mountain front into the southern Foothills or Anaktuvuk Plateau and eventually into the Arctic Ocean, about $110 \mathrm{~km}$ from its source.

Between the Jago and Okpilak Rivers the mountain front is oriented in an east-west direction. It veers northwestward from the Okpilak to the Hulahula River. The mountains range in altitude from $1700 \mathrm{~m}$ above sea 
level at the front, to peaks of nearly $3000 \mathrm{~m}$ southward in the Romanzof Mountains. Numerous snow-filled cirques and hanging and valley glaciers occupy these higher areas.

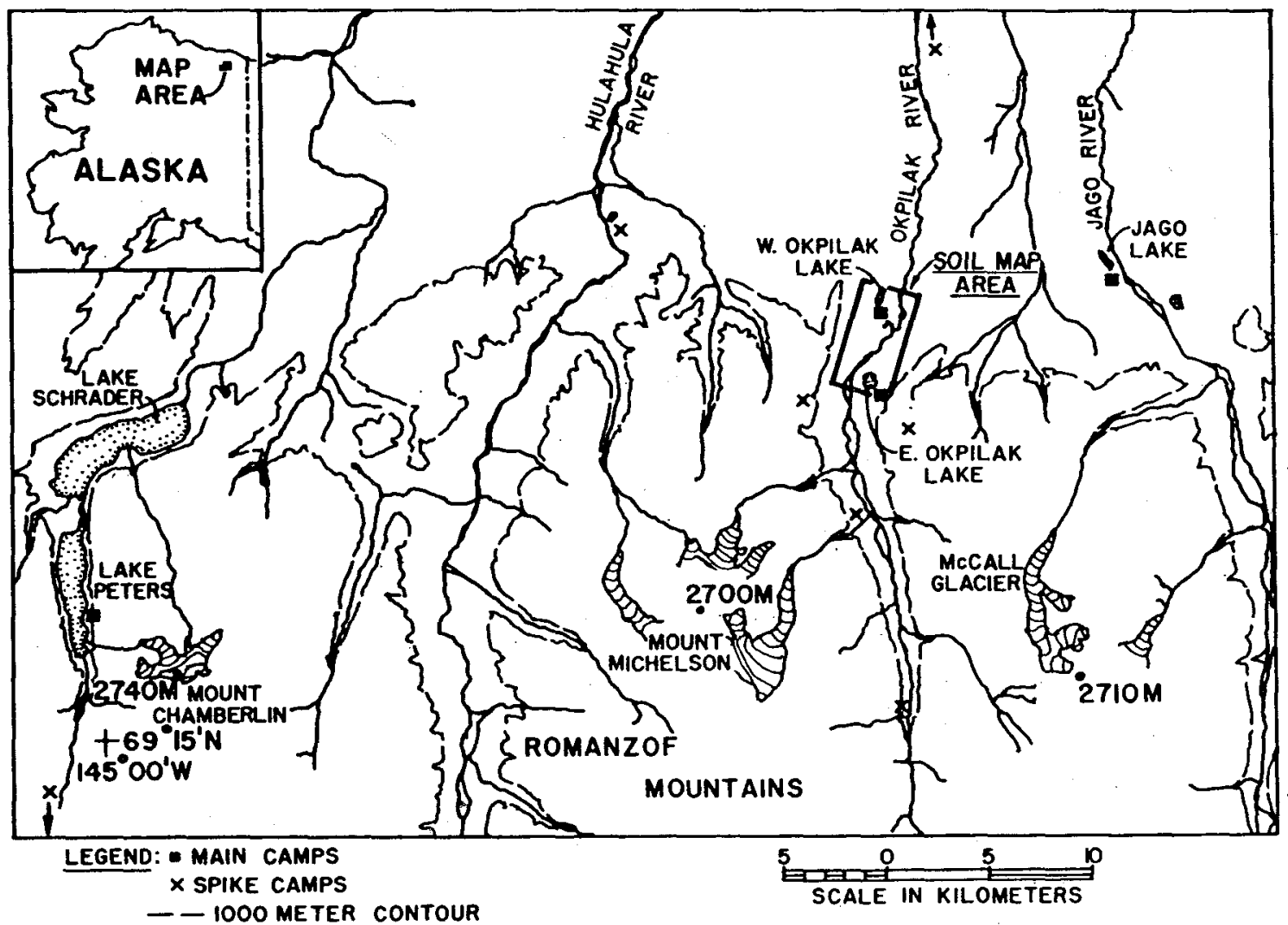

Figure 1. Topographic and index map of the Okpilak River region, Alaska.

Among the major valleys of the area, the Okpilak contains the largest amount of glacial features. Within the mountains, the valley walls are covered with lateral moraines and postglacial alluvial-colluvial cones or fans that rise upwards of $150 \mathrm{~m}$ above the broad valley floor. North of the mountain front, the valley is mantled by a series of end, recessional, ground, terminal and lateral moraines, kames and glaciofluvial outwash. The East and West Okpilak Lakes are glacially formed lakes. Wide, braided river channels are constricted at the mountain front as the river passes northward through several low moraines. Earlier glaciation overspilled the $500-\mathrm{m}$ valley wall and covered the rolling uplands with a mantle of drift. Later glacial advances left lateral moraines on the ridges and walls of the valley. The Jago Valley contains large amounts of morainic materials and many small glacial lakes north of the mountain front. The Hulahula Valley possesses few glacial features at the mountain front with an abundance of bedrock outcrops of mafic igneous rock. 
The mountainous terrain, for the most part, is steep and has much slide rock and organic mats. Between $1300 \mathrm{~m}$ and $1400 \mathrm{~m}$ above sea level, flat, apparently unglaciated mountain benches are present. These benches, mantled by a thick, frost-shattered regolith, contain extensive areas of patterned ground and resemble the altiplanation terraces of interior Alaska.

Figure 2 illustrates the relationship of the valley, upland, and mountain landscapes.

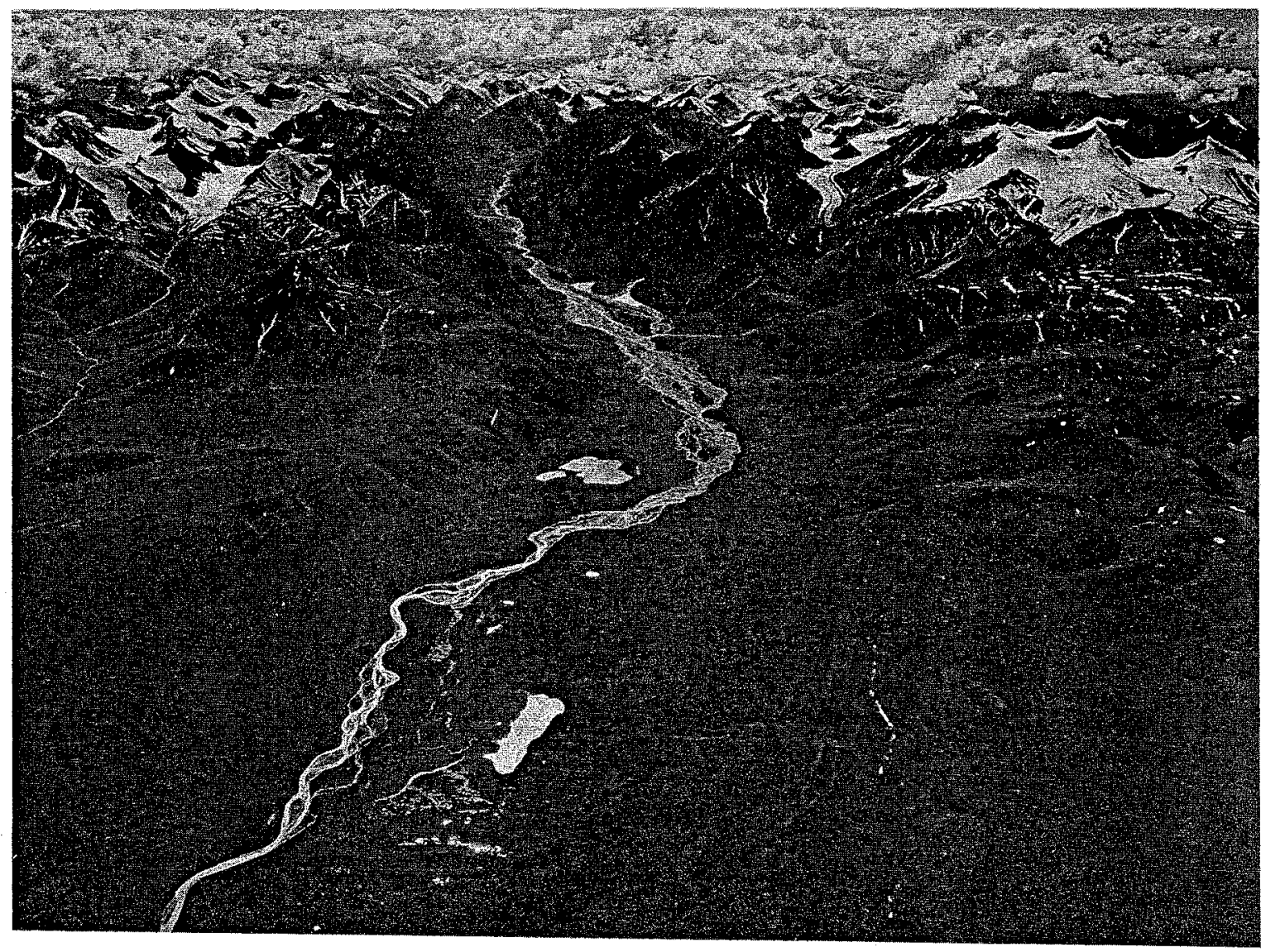

Figure 2. Aerial oblique photograph looking south onto the Okpilak River Valley and the adjacent uplands and mountains.

The Lake Peters and Lake Schrader area, about $35 \mathrm{~km}$ west-southwest of the Okpilak River, is dominated by two large glacial lakes. Lake Peters is surrounded by high mountains and bordered by fans and lateral moraines. Carnivore Creek, fed by a number of valley glaciers, empties into the south end of Lake Peters after flowing northward through a deep glacial trough for $12 \mathrm{~km}$. Roches moutonnees, fans, and till occupy much of the 
valley of Carnivore Creek. Lake Schrader north of Lake Peters and at the mountain front has an east-west alignment. It is bordered by moderately sloping, till-covered uplands and by unglaciated mountains.

Glacial and bedrock geology

It is generally recognized that the Brooks Range supported a network of valley glaciers during the late Pleistocene (Detterman et al., 1950). Valley glaciers descended northward from the Brooks Range and during earlier advances coalesced to form piedmont lobes. Bodies of drift and moraine from these older glaciations are found as far as $65 \mathrm{~km}$ north of the mountain front. At no time was there a continuous ice sheet in northern Alaska. More recent advances did not reach the mountain front.

Porter (1964) has established a late Pleistocene chronology for the north-central Brooks Range based on radiocarbon dating. The Itkillik glaciation with its four substages was correlated broadly with the classical Wisconsin glaciation. Three post-Itkillik advances, for which radiocarbon correlation was not made, are believed to be post-Hypsithermal and were restricted to the mountains. Apparently, very much the same glacial sequence is present in both the Okpilak and Lake Peters regions (Keeler, 1959; Sable, 1961, 1965; Kunkle, 1958; Holmes and Lewis, 1961). Brown $(1962 \mathrm{~b})$ noted that the degree of tussock development was not a reliable criterion for estimating relative ages of moraines. For example, the Jago Lake moraines (Itkillik or older) showed virtually no tussock development while outwash dated at 2830 years B, P. in Anaktuvuk Pass was well covered by cottongrass tussocks.

The Romanzof Mountains, through which the Okpilak River flows, contain an extensive system of valley glaciers between the Jago and Hulahula Rivers. Sable (1961) demonstrated that the terminus of Okpilak Glacier has receded approximately $300 \mathrm{~m}$ and that the lower part of the glacier has thinned approximately $50 \mathrm{~m}$ in the past 50 years. Sable concluded from these studies that the general shrinkage of valley glaciers in the Romanzof Mountains has occurred in the last half of the 19 th and first half of the 20th century. These findings are in accord with observations made in the McCall Valley, a tributary valley of the Jago River (Keeler, 1959).

The Romanzof Mountains are composed in part of a small granite batholith (Whittington and Sable, 1948; Sable, 1959, 1965). The granite is predominantly light- to medium-gray, coarse-grained rock with minor amounts of dark minerals. The granite is flanked on the south by the pre-Mississippian Neruokpuk formation, commonly composed of a greenish chloritic schist. Younger rocks form the mountains to the north and include the Lisburne group, the Sadlerochit, Shublik, Kingak and Ignek formations. Mafic igneous rocks are exposed along the Hulahula River. The stratigraphy of the area is complex.

\section{Vegetation}

The area north of the crest of the Brooks Range lies wholly within the tundra region and is characterized by treeless and grass-like vegetation. The valley and upland slopes are frequently tussock-covered. The high mountainous terrain is a lichen-covered barrens of frost- 
shattered bedrock. In general, barrens conditions increase, and marsh and meadow types decrease with increased altitude (Spetzman, 1959).

Cantlon (1961) divided the Arctic Slope into two zones: the arctic tundra (sea level to $1200 \mathrm{~m}$ ) and the arctic-alpine zone (above $1200 \mathrm{~m}$ ). Subzones of the former are littoral, typical, and shrub tundras. Two altitudinal belts are distinguished in the arctic-alpine zone: alpine tundra belt $(1200$ to $1800 \mathrm{~m})$ and alpine desert belt (above $1800 \mathrm{~m})$. The typical tundra subzone and the two altitudinal belts are found in the study area (see also Malcolm, 1959).

The typical tundra subzone is associated with July normal temperatures ranging from $6.7 \mathrm{C}$ to $11.1 \mathrm{C}$. Cottongrass tussock and dwarf-shrub meadows are extensive. The alpine tundra belt, a discontinuous subzone most widespread in the eastern Brooks Range, has a flora of 120 to 150 species. Dwarf birch and berry-producing shrubs are of minor importance or are absent. The alpine-desert belt occurs as a series of island-like peaks and shows a pronounced reduction in flora (10 vascular species) with the complete absence of shrubs and dwarf shrubs and the predominance of lichen barrens.

\section{Climate}

The climate of the Okpilak River region as well as the remainder of the northern Brooks Range is not well known. Summer climatic data (U.S. Weather Bureau) from Barrow, Barter Island, and Anaktuvuk Pass are presented in Table I for a 5-year period. Compared to Anaktuvuk Pass in the central Brooks Range both the Okpilak River and Lake Peters areas are influenced by a more maritime climate, having nightly ocean fogs and overall lower temperatures.

Conover (1960) estimated that the total annual precipitation may amount to $450 \mathrm{~mm}$ at the $600-\mathrm{m}$ elevation along the slope of the mountains. In much of the Arctic, about one-half of the annual precipitation occurs during the summer. Estimates from the author's field observations accounted for at least $150-200 \mathrm{~mm}$ of precipitation during the predominantly "snow-free period." In the Brooks Range, the estimated snow cover of $850 \mathrm{~mm}$ usually disappears by late May or early June. Frequent light rain and snow storms are common throughout the summer months. At higher altitudes, precipitation probably increases in the form of more frequent light rains, showers and fog. Relative humidity is high throughout the mountainous region during the summer months.

July is the warmest month with mean temperatures varying locally from 5.6C to 12.2C. Maximum temperatures in the low 20's and minimum temperatures below $-10 \mathrm{C}$ are not uncommon during the summer. Mean annual temperatures are common by mid-September. Mean daily temperatures are below freezing for at least 8 months of the year. Conover (1960) estimated a decrease in temperature along the mountain front of $2.2 \mathrm{C}$ per $300-\mathrm{m}$ increase in altitude. Scattered temperature records and field observations of temporary summer snowlines substantiate a decrease of this magnitude (Tedrow and Brown, 1962). The overall summer climate can be extremely variable, but it is generally wetter and warmer than the coastal areas. 
Table I. Comparative summer climatic data for Barrow, Barter Island, and Anaktuvuk Pass (1957-1961).

Avg monthly temp $\left({ }^{\circ} \mathrm{C}\right)$

Barrow Barter Anaktuvuk Island
Avg monthly precipitation ( $\mathrm{mm}$ ) Barrow Barter Anaktuvuk Island
Pass

1957

\begin{tabular}{|c|c|c|c|c|c|c|c|}
\hline June & 0.8 & 0.8 & 9.3 & & 27 & 5 & 15 \\
\hline July & 4.1 & 4.8 & 10.8 & & 20 & 24 & 33 \\
\hline August & 5.6 & 7.8 & 10.0 & & 35 & 41 & 33 \\
\hline September & $-1 \cdot 7$ & $-1 \cdot 1$ & 0.1 & & 28 & 76 & 47 \\
\hline 4-month avg & $\overline{2.2}$ & $\overline{3.1}$ & 7.5 & Total & $\overline{110}$ & $\overline{146}$ & $\overline{128}$ \\
\hline \multicolumn{8}{|l|}{1958} \\
\hline June & 1.2 & 2.3 & 11.2 & & 20 & 4 & 145 \\
\hline July & 3.5 & 7.4 & 12.1 & & 15 & 4 & 31 \\
\hline August & 5.9 & 7.3 & 9.2 & & 20 & 4 & 26 \\
\hline September & 1.9 & 2.6 & 0.8 & & 40 & 18 & 15 \\
\hline 4-month avg & $\overline{3.1}$ & 4.9 & 8.4 & Total & $\overline{95}$ & $\overline{30}$ & $\overline{2} \overline{17}$ \\
\hline \multicolumn{8}{|l|}{1959} \\
\hline June & 1.1 & -0.1 & 10.3 & & 5 & 3 & 23 \\
\hline July & 1. 9 & 3.8 & 7.2 & & 36 & 50 & 49 \\
\hline August & 2.8 & 1.9 & 7.2 & & 29 & 42 & 38 \\
\hline September & -1.0 & -1.4 & -0.8 & & 29 & 3 & 5 \\
\hline 4-month avg & 1.2 & 0.8 & $\overline{8.0}$ & Total & 99 & $\overline{98}$ & $\overline{115}$ \\
\hline \multicolumn{8}{|l|}{1960} \\
\hline June & 0.8 & 1.1 & 7.3 & & 7 & 13 & 33 \\
\hline July & 3.1 & 3.3 & 9.2 & & 5 & 18 & 36 \\
\hline August & 1,2 & 3.3 & 6.4 & & 37 & 17 & 29 \\
\hline September & -4.1 & -1.4 & -4.3 & & 13 & 19 & 31 \\
\hline 4-month avg & $\overline{0.3}$ & 1.6 & $\overline{4.7}$ & Total & 62 & 67 & $\overline{129}$ \\
\hline \multicolumn{8}{|l|}{1961} \\
\hline June & 1. 4 & 1.9 & 9.2 & & 2 & 20 & 39 \\
\hline July & 3.4 & 4.8 & 10.1 & & 46 & 71 & 95 \\
\hline August & 1.9 & 3.4 & 7.3 & & 33 & 28 & 35 \\
\hline September & $\underline{1.0}$ & 0.6 & 3.2 & & 8 & 22 & - \\
\hline 4-month avg & $\overline{1.9}$ & $\overline{2.8}$ & $\overline{7.5}$ & Total & 89 & $1 \overline{41}$ & $(169)$ \\
\hline $\begin{array}{l}\text { Average for } \\
5 \text {-year period }\end{array}$ & 1.7 & 2.6 & 7.2 & & 91 & 96 & 152 \\
\hline
\end{tabular}




\section{PART II. CRYOPEDOLOGY AND THE DISTRIBUTION OF SOILS AND SURFACE FEATURES}

Manifestation of frost action in the soil

In the Arctic, the mechanical differentiation of soil material into sorted ground features, the occurrence of nonsorted surface configurations, the presence of buried organic layers in mineral soils, the existence and melting of massive ground ice, and frost action result in a lack of soil continuity and a diversity of microrelief configurations that are perhaps unequalled in any other climatic region of the earth. Smith (1956) noted that moving soils were more common than stable soils under the influence of an arctic climate. Nikiforoff (unpubl.) portrayed the horizons of tundra soils as being mechanically restless as a result of horizontal and vertical movements year after year. Douglas (1961) stated that frost action was a special soil-forming process of the tundra.

Britton (1957) aptly summarized the physical aspects of cryopedology in the following statements:

"Cryopedologic processes include all mechanisms operative in the substrate that relate to the formation and degradation of permafrost, as well as all frost-cracking, -splitting, -churning, -stirring, -thrusting, and -heaving actions, induced either by expansion and contraction of frozen materials exposed to large temperature stresses, or to a repeated alternate freezing and thawing of surface materials. All such processes are products of the climate operating on materials consisting of anything from bedrock to boulders, and all size classes of materials to silts, clays, and organic layers. These materials are of varying water content, disposed on all gradations of slope, and variously blanketed by vegetation and seasonally by snow. Out of such complexes, intricate operations of unique combinations of processes produce characteristic minor relief features."

In the glaciated valleys and uplands and the older periglacial mountainous areas of the Brooks Range, cryopedologic processes produce microrelief features and complexities in soil morphology at a greater frequency than is encountered on either the Foothills or Coastal Plain provinces of northern Alaska (Brown, 1962b; Tedrow and Brown, 1965).

The fact that the mountain and valley terrains are mantled by frost features to such a degree may be partly explained in several ways:

(1) The valleys and uplands are covered with till, a highly heterogeneous material which is easily sorted (Corte, 1959). (2) The unglaciated mountainous terrain (approximately above $1200 \mathrm{~m}$ ) has probably been exposed to a longer period of frost activity than other comparable bedrock landscapes. Therefore, sorting and the development of patterned ground are more likely to be present. (3) The strong relief in both the valleys and mountains favors solifluction and the development of surface configurations which are typical of areas of perennially frozen ground (Fig. 3) (Sharp, 1942; Smith, 1956; Washburn, 1956). 
The effects of frost action in the soils of the Okpilak River region are considered under two general forms: 1) the surficial configuration or patterned ground and 2) the internal morphological characteristics found in the seasonally thawed soil and near-surface perennially frozen ground. Before discussing the individual soils and surface features, morphological examples of the effect of frost action in these soils are considered.

The instability of soils on slopes is manifested by soil terraces, lobate terraces, soil lobes, mudflows, stripes, and a variety of more nondescript microrelief features, all of which are gradational to some extent. Downslope movement of soil materials is enhanced by the presence of a perennially frozen substratum. These soils of the solifluction slopes possess no orderly profile characteristics. They present no systematic means of description; however, all contain buried organic matter (Fig. 4). The soils range from moderately well-drained to wet viscous masses. As the soil surface slowly moves downslope organic matter is buried by a folding under process which results in a lack of profile continuity. Frequently, this buried material is traceable to the surface as one excavates upslope through the various microrelief features. The frontal portion is usually organic with the amount of mineral soil increasing upslope. The buried organic zone is generally just above the base of the seasonally thawed soil. Further upslope, the thawed zone is considerably thicker (Fig. 5, 6).

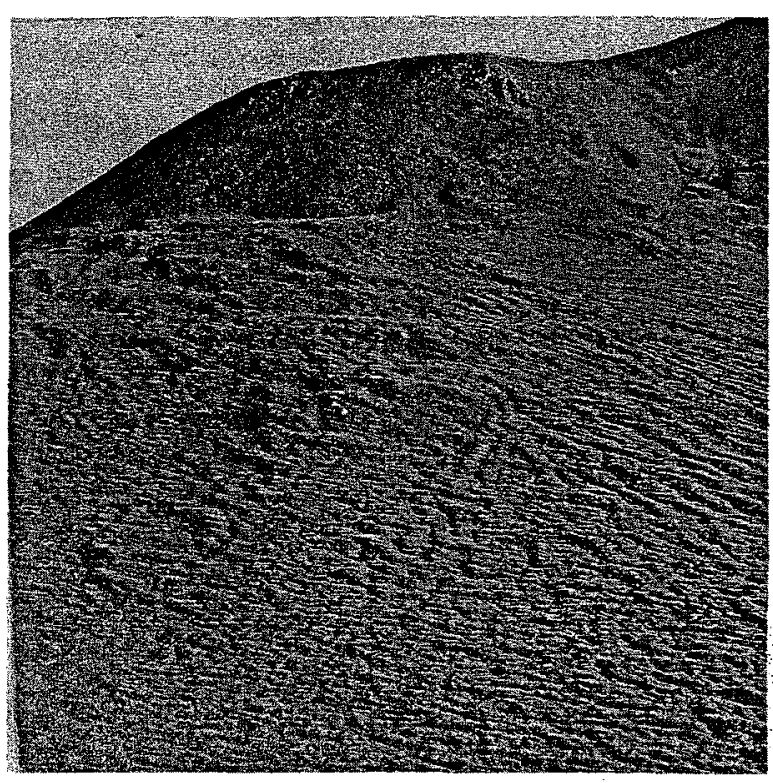

Figure 3: Solifluction slope of the unglaciated uplands.

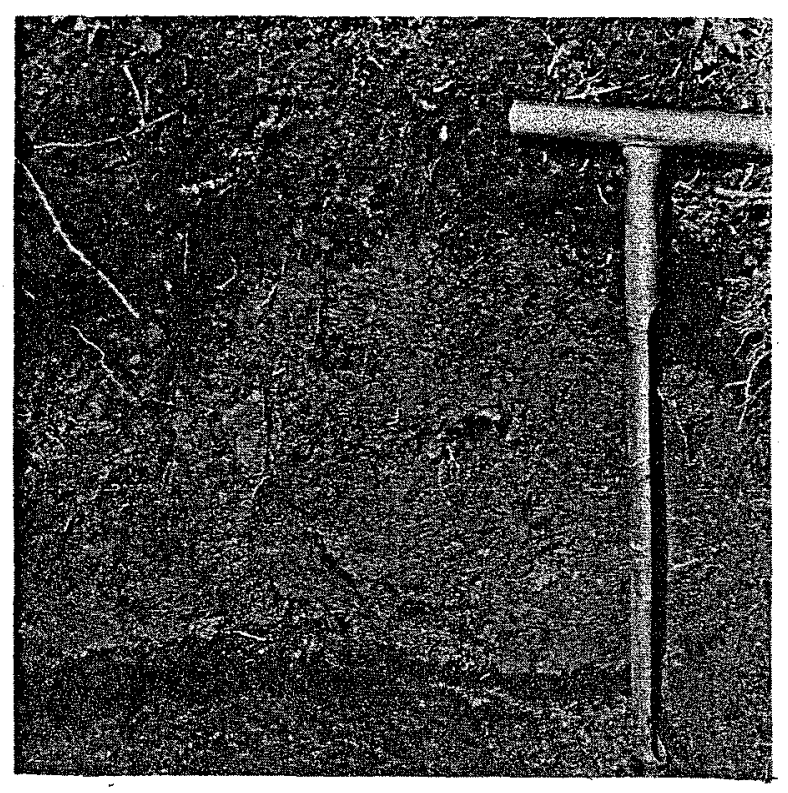

Figure 4. Soil of the solifluction slope with characteristic buried organic layer above the frost table. 


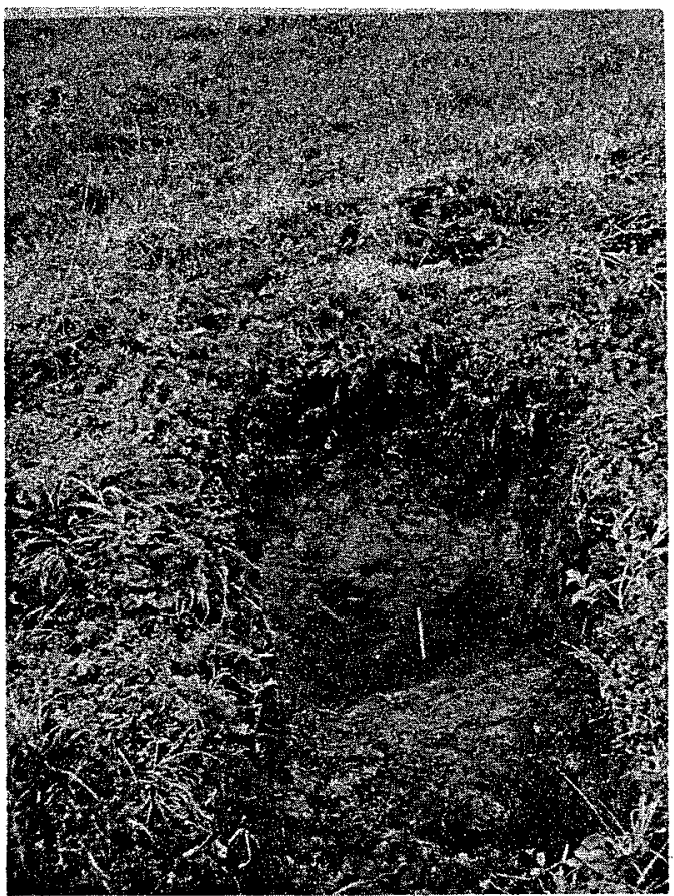

Figure 5. Cross section through the frontal portion of a solifluction terrace. Pencil rests on frost table.

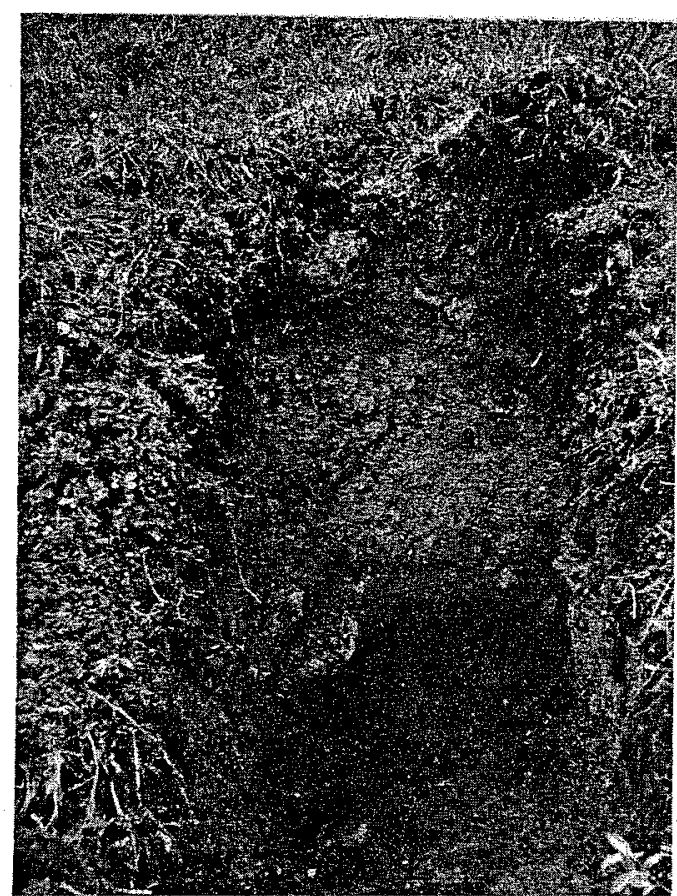

Figure 6. Cross section through the upslope portion of solifluction terrace (Fig. 5). Note thicker zone of thawed soil and dark buried organic matter.

Differences in the thickness of the seasonally thawed soil are common across small distances on both the solifluction slopes and level terrain. For a raised mound the thawed zone is approximately $45 \mathrm{~cm}$ thick in the center of the mound and $25 \mathrm{~cm}$ in the adjacent trough (Fig. 7, 8). Differences in moisture content, thickness of organic surfaces, and microrelief account for these variations in the depth of seasonal thaw.

Evidence for recent fluctuations in the depth of thaw was observed on the south-facing slope above Porcupine Lake. The remains of a dead willow were found in an organic mat associated with a shallow depth of soil thaw and embedded in soil having a high ice content (perennially frozen ground)(Fig. 9, 10). It is unlikely that the shrub grew to a height of over a meter in the present shallow depth of thawed soil. Therefore, a rise in the seasonal frost table was postulated. This rise could have been caused by a regional change in climate, a local shift in drainage, or an increase in the insulating quality of the organic mat. In any event, this reduction in depth of thaw demonstrates one aspect of the dynamic character of the wetter soil. 


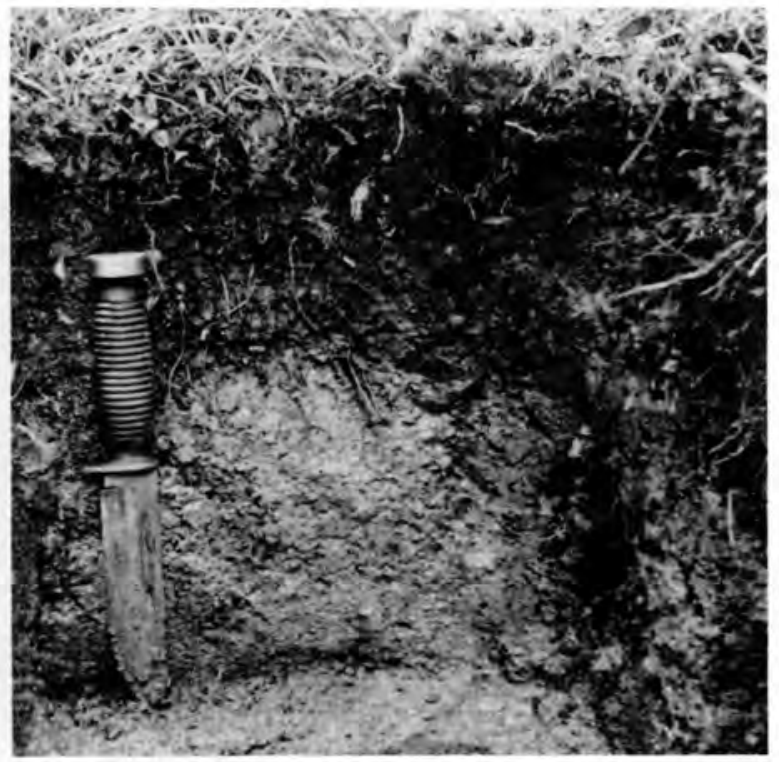

Figure 7. Approximately $25 \mathrm{~cm}$ of thawed soil adjacent to a frost scar mound $\left(\mathrm{S}_{\mathrm{M}}\right.$, Fig. 32; see Table III for code).

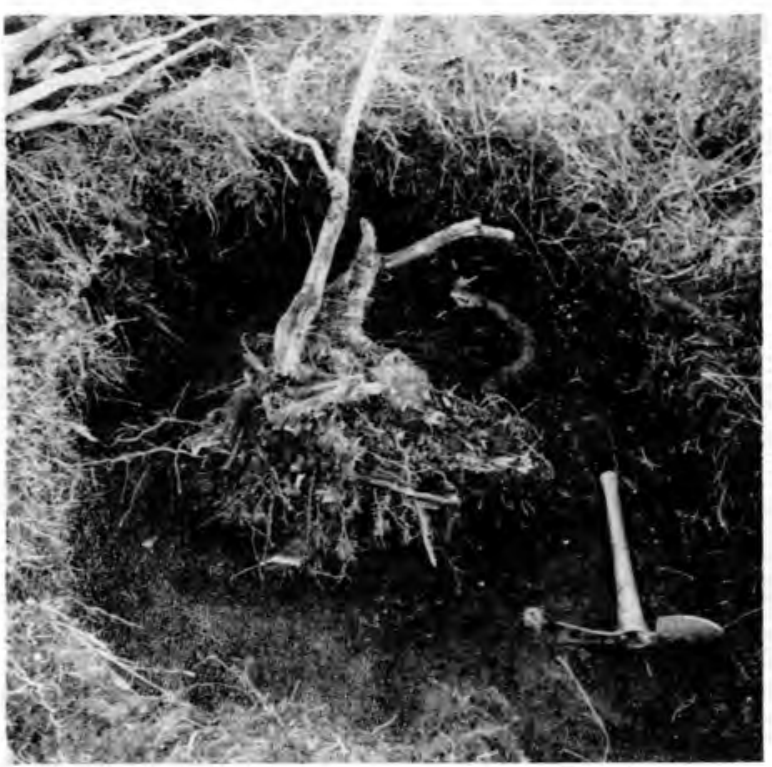

Figure 9. Base of dead willow shrub in a shallow, seasonally thawed organic layer.

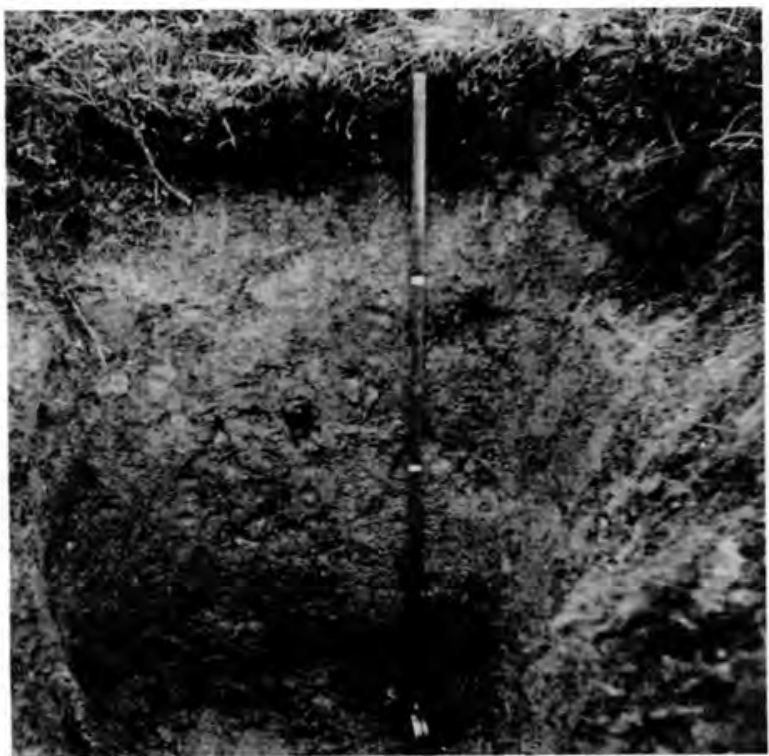

Figure 8. Approximately $45 \mathrm{~cm}$ of thawed soil in the center of the same frost scar moind (Fig. 7).

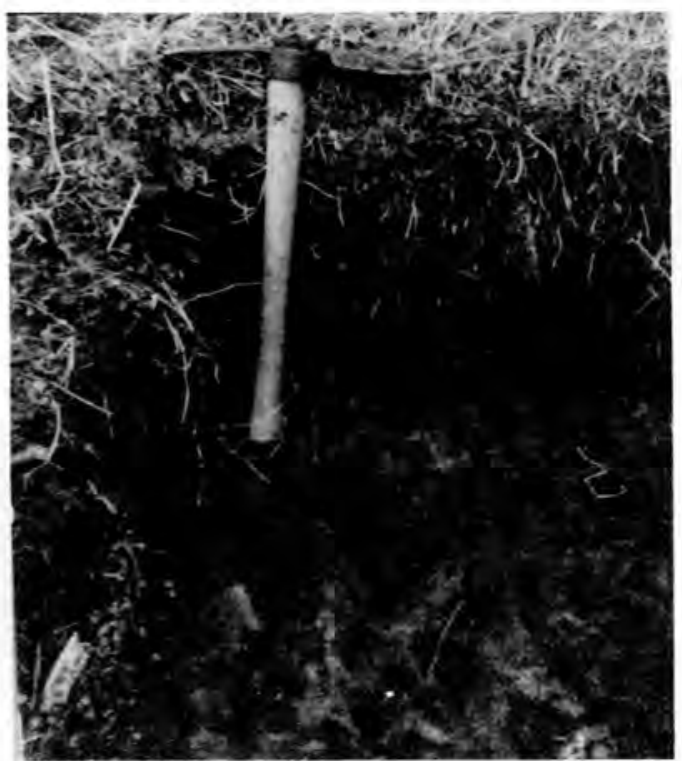

Figure 10. Top of present-day frost table from which dead willow was removed (Fig. 9). Note mixture of ice and frozen soil. 
The nonsorted steps and stripes are cases of instability on gentle slopes. Relatively dry soil material of ten overlies buried organic surfaces. In early spring, when mineral soil is close to saturation and the frost table is near the surface, the soil flows more readily (Fig. 11). However, all such burials are not of this type, particularly where the overburden is thick and cobbly (Fig. 12).

Sorted nets and polygons demonstrate the lack of continuity of soil morphology on relatively flat terrain. In the depressed troughs virtually no fines are present for a depth of $1 / 2 \mathrm{~m}$. This sorting may be attributed to the lateral and vertical segregation of particles (Corte, 1963) although erosion of fines should not be completely disregarded (Fig. 13). The desert pavement is another extreme soil condition. The pavement consists of a loose, coarse gravel, devoid of fines. The amount of fines increases with depth. Downward migration of fines caused by repeated freezing and thawing may be responsible for this phenomenon, but the erosive effect of wind is also a contributing factor (Fig. 14).

Frost scars, boils, peat rings, and the like are extremely common in all stages of development on the wet glaciated terrain. Cross sections of these show lateral burial of surface matter. The viscous mineral soil is displaced, first upwards and then outwards, by the "frost-churning process." This results in the burial of surface organic mats. The soil adjacent to frost scars contains vertical lobes and horizontal layers of the buried peat or poorly sorted pockets of cobbles (Fig. 15,16).

Douglas (1961) discussed the buried organic horizons associated with wet tundra soils on level terrain. This universal presence of buried organic matter in tundra soils is thought to represent the result of a climatic change, in which a cooler period caused the thickness of seasonally thawed soil to decrease. This decrease resulted in an increased soil volume which forced the upwelling of the mineral soil through the organic surface, and burial of the latter. Generally, radiocarbon age determinations of these buried peats show they are between 8000 and 10000 years old (Tedrow, 1965). A radiocarbon date of one such buried peat layer from Anaktuvuk Pass yielded an age of $4750 \pm 100$ years (Trautman, 1963). From observations in the glaciated regions of northern Alaska, the author believes that the occurrence of these buried surfaces and the present frost scars are related. That is, the buried organic matter is also the result of comparatively recent frost scar development.

The presence of ground ice and particularly ice wedges in the substratum similarly serves to produce disorder and instability in soil morphology. Numerous ice wedges are found in the peaty soils and in large meltout polygons on peat-covered fans and slopes in the Okpilak Valley (Fig. 17). Maximum melt-out of these ice wedges reaches depths of $3 \mathrm{~m}$. As ice wedges increase in size, the soil mass is compacted and/or displaced, thereby distorting normal soil morphology. Ice-core hummocks are also common.

Vesicular structure in the soil is frequently found under bare surfaces associated with various patterned-ground features. It consists of closely packed, spherical to ellipsoid voids of various sizes, the largest seldom exceeding $1 \mathrm{~cm}$ across (Fig. 60), occurring across a wide soil moisture range. In the wetter soils it is difficult to observe when trenching, since the soil mass flows readily with the subsequent collapse of the vesicular cavities. The cavities may form as a result of evolution of air from soil water as 
freezing occurs and subsequent entrapment of the air in the soil mass. In his studies on desert soils, Springer (1958) produced similar vesicular structure by drying and wetting. Crocker and Major (1955) reported the same structure on bare to sparsely covered mineral patches on moraines near Glacier Bay. The soil mass associated with the vesicular structure usually exhibits a convex surface. Both convex surface and weakly developed vesicular structure were reproduced in the laboratory by repeated freezing and thawing of a nearly saturated soil sample obtained from an actual frost scar. The particle-size distributions of two soils exhibiting vesicular structure are shown in Table II. In frost scars, granular aggregates are occasionally encountered under a thin mineral crust and over the zone of vesicular structure. A fine platy structure is also occasionally present in the surface horizon. Both may be caused by the formation and later melting of ice lenses.

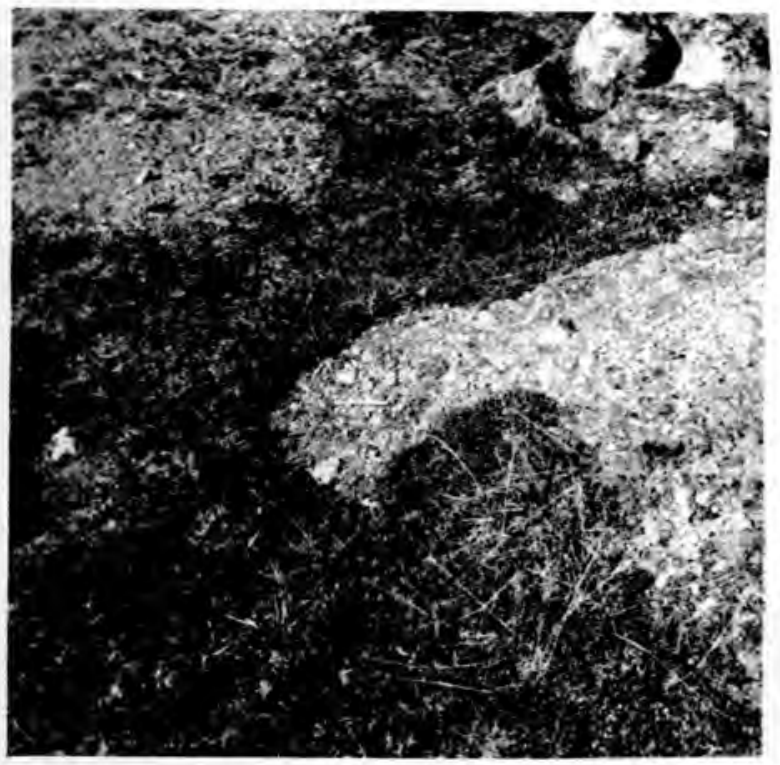

Figure 11. Flow of gravelly soil resulting in the burial of surface vegetation.

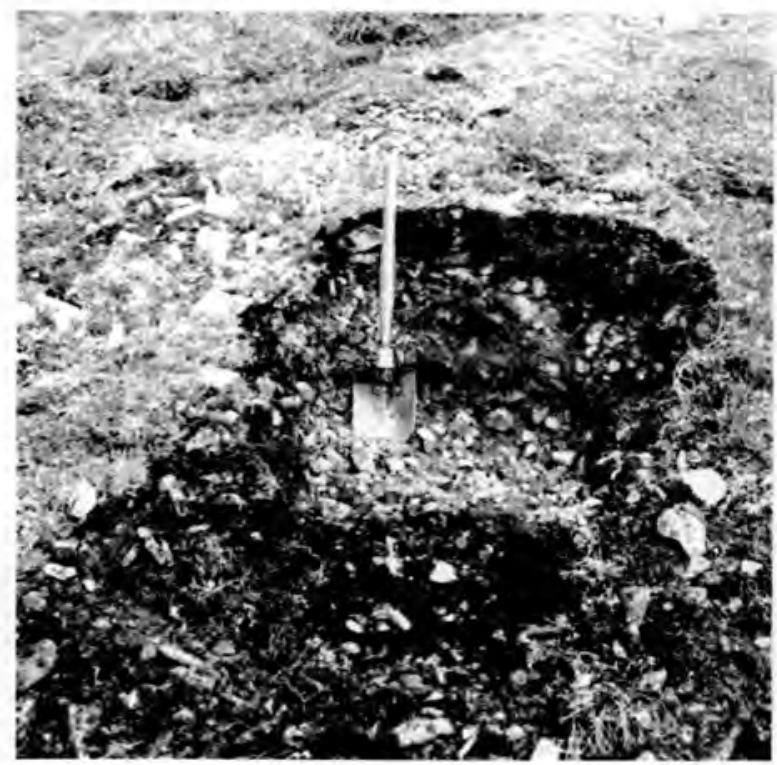

Figure 12. Buried surface (top of shovel blade) in cobbly colluvium.

Table II. Particle-size distribution ( $\%)$ of two soils exhibiting vesicular structure.

$\begin{array}{ccccccc}2-1 \mathrm{~mm} & 1.0-0.5 & 0.5-0.25 & 0.25-0.10 & 0.10-0.05 & 0.05-0.002 & <0.002 \\ 16 & 15 & 13 & 9 & 10 & 33 & 4 \\ 10 & 12 & 13 & 11 & 11 & 41 & 2\end{array}$




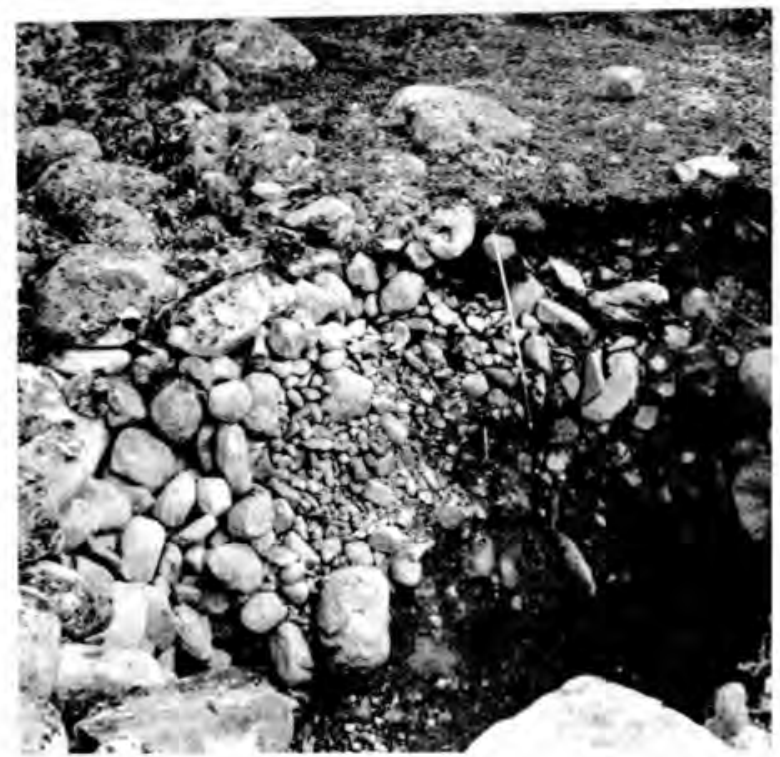

Figure 13. Sorted gravels in the trough of a stone net (photo, courtesy of F. C. Ugolini).

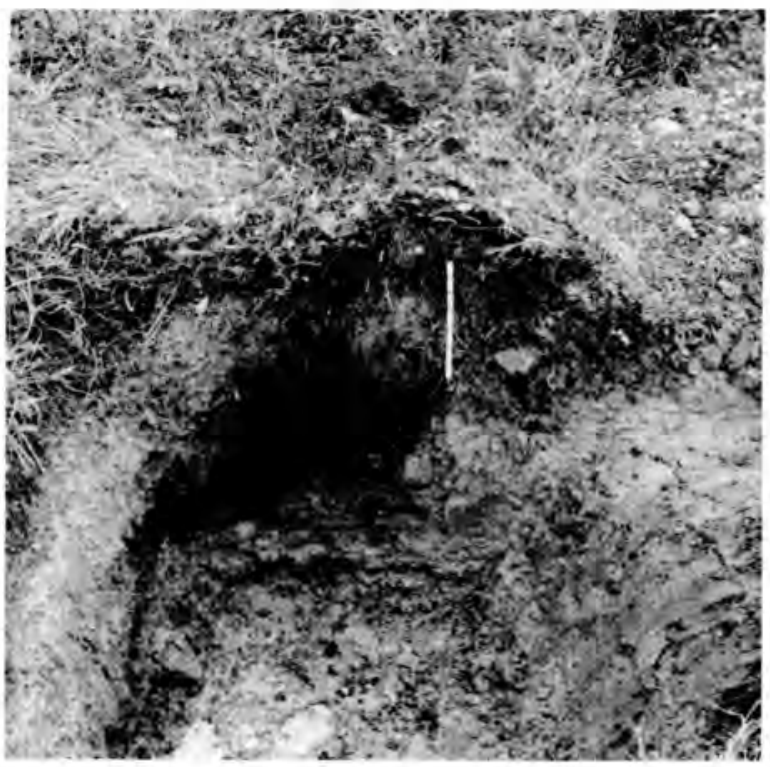

Figure 15. Turned-under peat adjacent to weakly developed peat ring ( $\left.R_{p}, F i g .29\right)$.

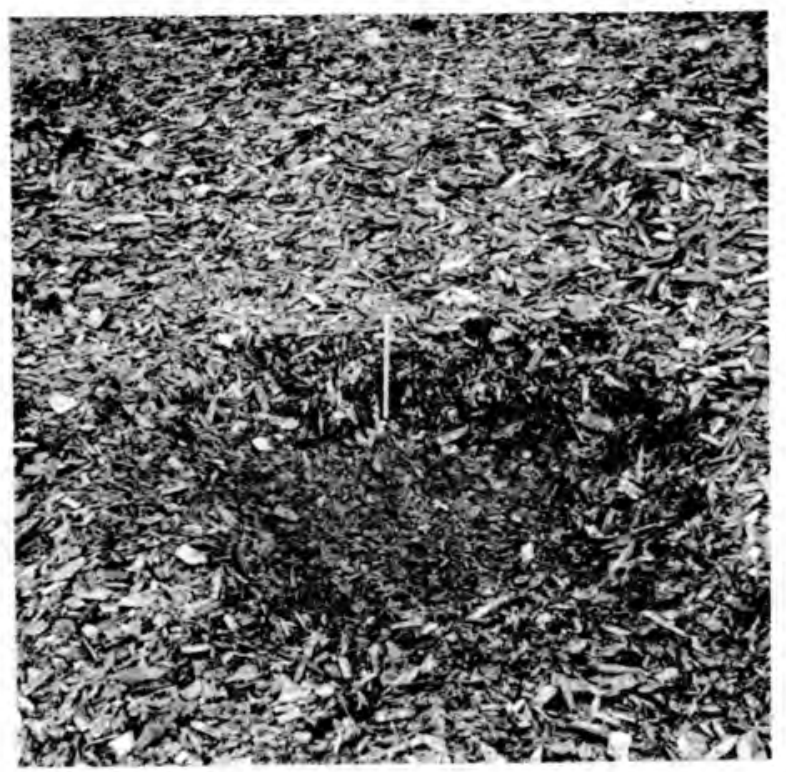

Figure 14. Pavement of slaty rock fragments devoid of fines.

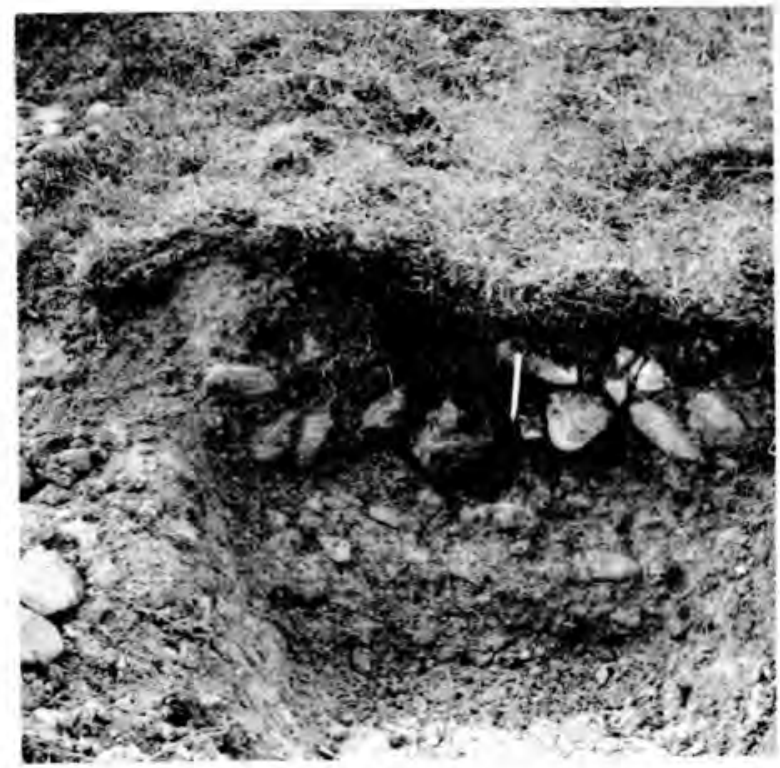

Figure 16. Opposite side of same peat ring, but with pocket of sorted gravel instead of buried peat lobe (Fig. 15). 


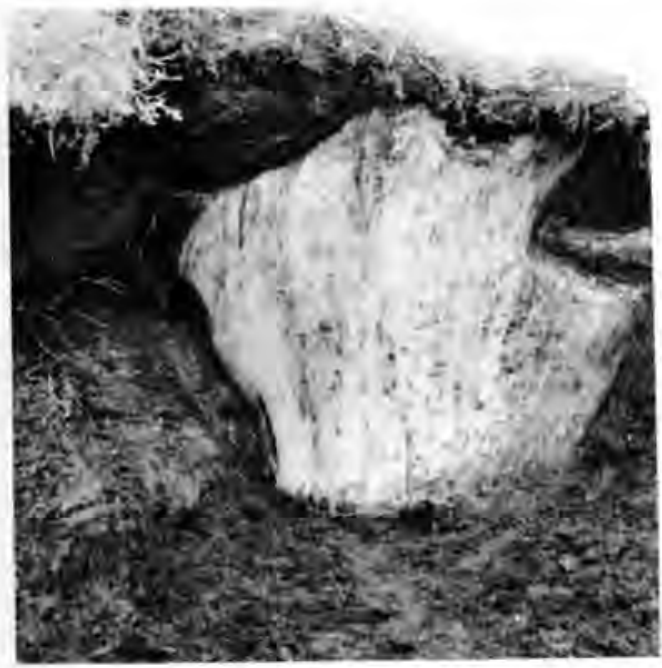

Figure 17. Large ice wedge in peaty deposit.
It is obvious from this brief discussion that a considerable segment of arctic soil morphology is the result of the alternate freezethaw processes that have occurred in the past and are presently active in these soils. Figure 18 summarizes some of these morphological characteristics. With this perspective, it is now appropriate to discuss the complex distribution of the soil and surface features in the Okpilak River region.

Types and distribution of soils and surface features

The subject of soil classification in arctic Alaska and the relationship to surface features has been dis cussed by Tedrow et al. (1958) and Drew and Tedrow $(19 \overline{62})$. The genetic soils include the lithosols and regosoils, the well-drained arctic brown soils, the wetter glei tundra soils, and the organic bog soils. Detailed soil mapping in arctic Alaska is limited. Tedrow and Hill (1954) mapped the Umiat and four other areas and based their classification upon lithology, origin of parent materials, and relative degree of soil drainage. Drew (1957) presented a soil map of the Barrow area and utilized the genetic soils, parent materials, relative wetness, and stage of ice-wedge polygon development in his legend. MacNamara (1964) has recently completed a soils map of the Howard Pass quadrangle $\left(68^{\circ} \mathrm{N}\right.$, $\left.156^{\circ} \mathrm{W}\right)$. For the present study, it was considered desirable to systematically describe and map the numerous soils, soil conditions, and surface features for part of at least every major terrain component in the Okpilak River region. These included the glaciated valleys and upland slopes and the unglaciated mountain slopes and benches. A summary of this approach to mapping the complex soils environment follows.

The soils and surface features encountered in this region are presented in Table III. The arrangement is not intended to imply a genetic classification for either the soil or surfacr features. This legend is simply an expedient approach to the grouping and mapping of the numerous and often gradational forms of ground and soil conditions. Washburn's (1956) classification of patterned ground is employed for the majority of the patterns. The less regular and nonrepetitious forms and surface markings are grouped in a miscellaneous category. The genetic soils and the previously undescribed soil conditions are arranged in eight groups. With the exception of the mats and alluvial-colluvial soils, and soils of the solifluction slopes, these groups collectively comprise a soil drainage catena. Terms such as "raw" and "inundated" tundras are descriptive and do not imply processes of soil formation. Numbers alone, rather than terms, could easily suffice if soil terminology is considered burdensome. 

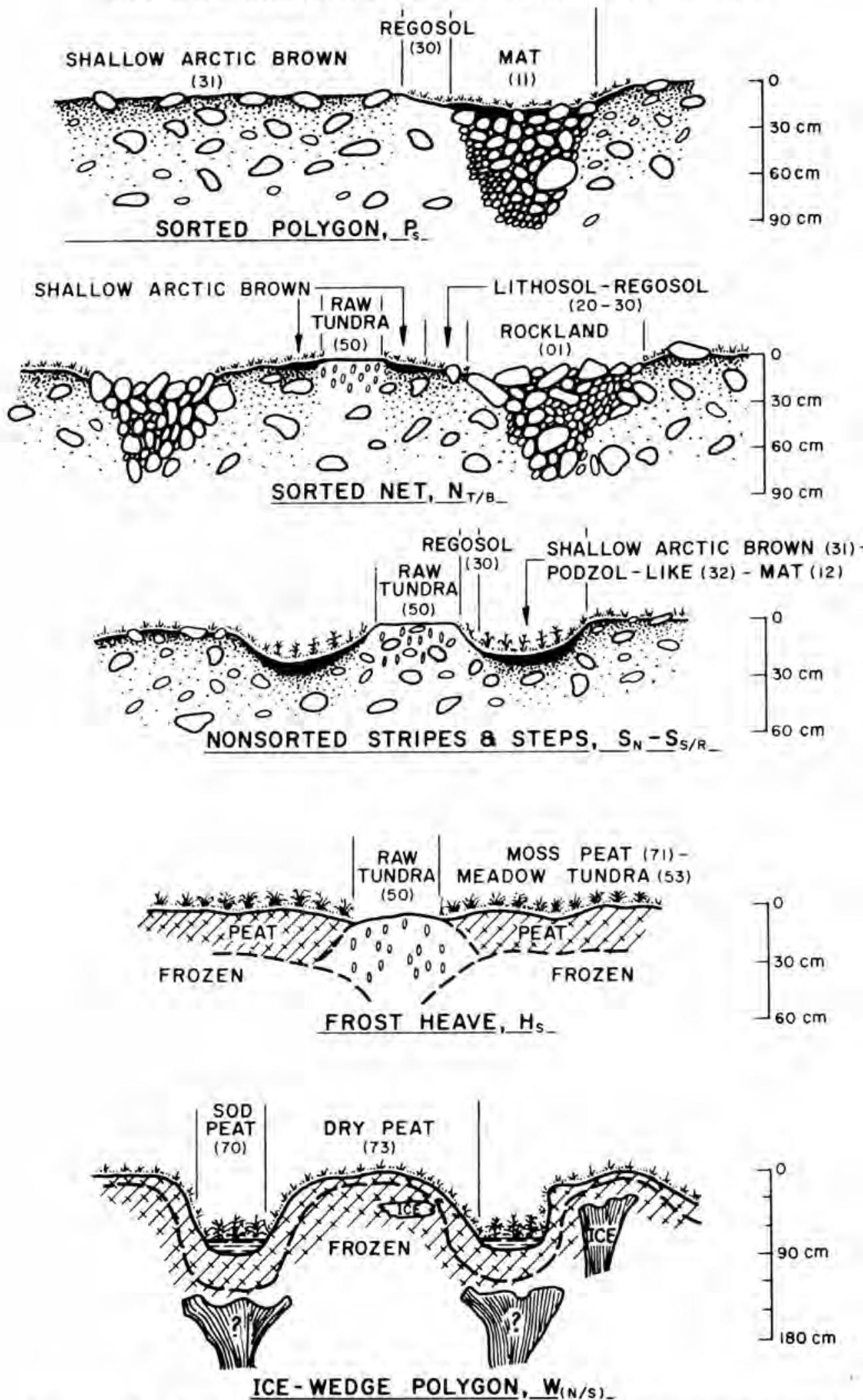

Figure 18. Variations in surface features and soil morphology as a result of frost action. 
Table III. Mapping legend for the Okpilak River region, Alaska (see Fig. 69).

Surface features

\begin{tabular}{|c|c|c|}
\hline Group A (after Washburn) & Code & Figure \\
\hline $\begin{array}{l}\text { Sorted nets } \\
\text { Nonsorted nets }\end{array}$ & $N_{T} / B$ & 20,21 \\
\hline Stone centered & $N_{S N} / S S$ & 22 \\
\hline Polygonal intergrade & $\mathrm{N}_{P}$ & 24 \\
\hline Sorted polygons & $\mathrm{PS}_{\mathrm{S}}^{2}$ & 25 \\
\hline Nonsorted ice-wedge polygons & $W_{N} / S$ & 26,27 \\
\hline Sorted circles & $\mathrm{S}_{\mathrm{C}}$ & 28 \\
\hline Nonsorted circles & & \\
\hline Peat rings & $\mathrm{R}_{\mathrm{P}}$ & 29 \\
\hline Frost scars & $S_{F}^{\perp} / F S$ & 30 \\
\hline Frost scar mounds & $\mathrm{S}_{\mathrm{M}}$ & 32 \\
\hline Inundated mounds & $\mathrm{M}_{\mathrm{I}}$ & 33 \\
\hline Nonsorted steps & $S_{N}$ & 34 \\
\hline Nonsorted stripes & $\mathrm{S}_{\mathrm{S}} / \mathrm{R}$ & 35 \\
\hline Group B (miscellaneous types) & & \\
\hline $\begin{array}{l}\text { Solifluction mounds and terraces } \\
\text { Hummocks }\end{array}$ & $S_{\mathrm{T}}$ & 36 \\
\hline Moss & $\mathrm{H}_{\mathrm{M}}$ & 37 \\
\hline Peaty mound & $\mathrm{HP}_{\mathrm{P}} / \mathrm{PS}$ & 38, \\
\hline Frost heaves & & \\
\hline Silt oozes & $\mathrm{H}_{\mathrm{S}}$ & 40 \\
\hline Rubbly heaves & $\mathrm{H}_{\mathrm{R}}$ & 41 \\
\hline Ice mounds & $\mathrm{H}_{\mathrm{I}}$ & 42 \\
\hline Rock debris benches & $D_{B}$ & 43 \\
\hline Rubble pits & $\mathrm{P}^{\mathrm{D}}$ & 44 \\
\hline Mudflows and slides & $\mathrm{M}_{\mathrm{F}} / \mathrm{S}$ & 45 \\
\hline Strangmoor and peat ridges & $\mathrm{S}_{\mathrm{G}}$ & 47 \\
\hline Levees & L & 48 \\
\hline Trails & $T$ & 49 \\
\hline
\end{tabular}

Soils

Rockland

Mats and alluvial-colluvial substrata

Recent alluvium

Mat on rubble and bedrock

Mat on well-drained substratum

Mat on poorly-drained substratum

Stratified sediments

Shallow soils on bedrock

Lithosol

Shallow arctic brown

Shallow soils on transported materials

Regosol
Shallow arctic brown
Podzol-like soils

Podzol-like soils

Moderately deep, well drained soils

Normal arctic brown

Arctic brown mull and humus carbonate

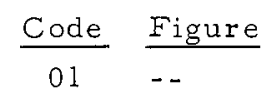

Tundra soils on wet mineral substrata Raw tundra

Upland tundra

Inundated tundra.

Meadow tundra

Organo-mineral tundra

Soils of the solifluction slope

Organic soils

$$
\begin{aligned}
& \text { Sod peat } \\
& \text { Moss peat } \\
& \text { High moss peat } \\
& \text { Dry peat }
\end{aligned}
$$

Bog

NOTES: / represents two different forms of same feature

Relatively dry moraine complex (Fig. 19) includes: 
Table IV. Occurrence of soils with surface features.

Soils

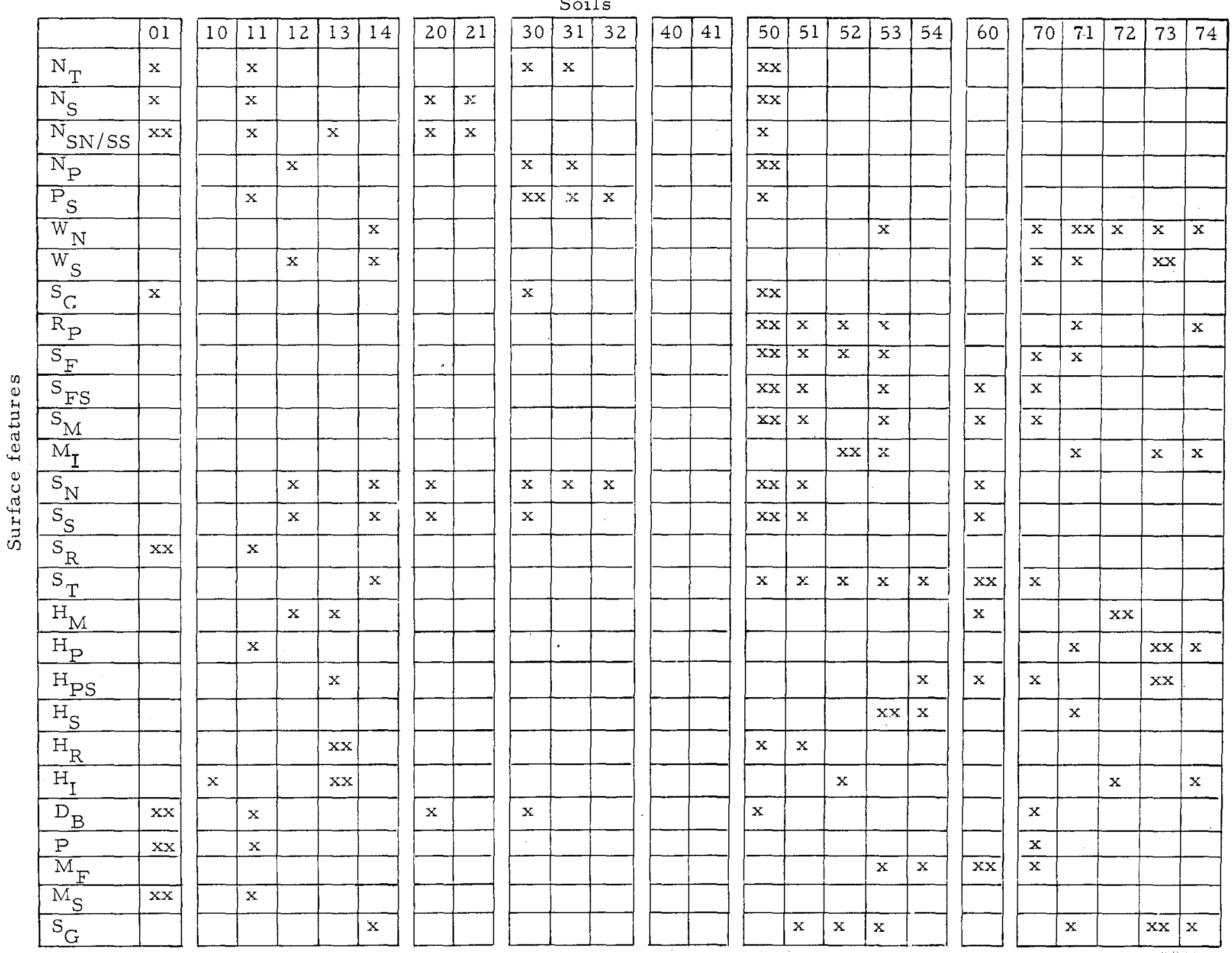




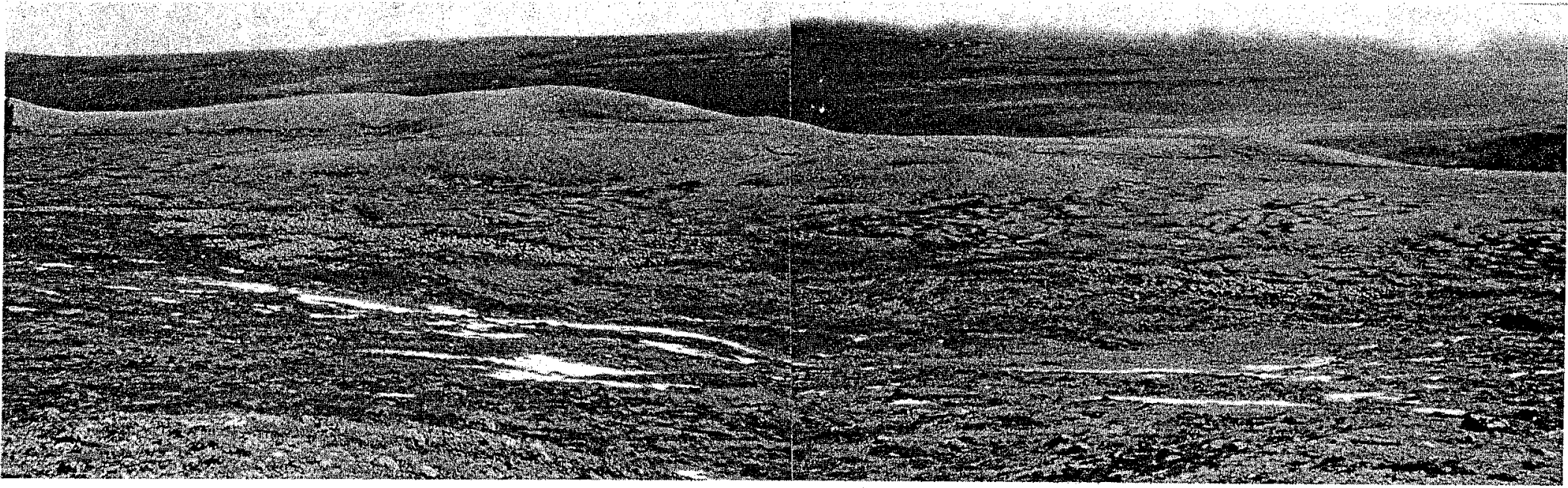

Figure 19. Relatively dry moraine complex with numerous sorted and nonsorted features. 
The occurrence of these soils and surface features as determined by field studies is presented in Table IV. Usually three to five distinctly different soils occur within an individual surface feature. The table indicates the soils that may be anticipated within any one feature. The use of this table enables the extrapolation of a number of soil conditions from a limited number of symbols on the map.

In practice, mappable units are delineated by field observations and from aerial photo interpretation on an appropriate scale. Within each mappable unit the codes for the predominant patterns and soils are arranged in order of decreasing frequency. This approach, as applied to the Okpilak River region, northern Alaska, should satisfy recent criticism for the failure to map interrelationships of soils and microrelief in northern Alaska (Mikhailov, 1961). A preliminary soils map of the Okpilak River region was prepared based upon this system (Brown, 1962b), and a portion of it is presented in Figure 74 (p.45). A brief description of the surface features and soils employed in the mapping is presented below:

\section{Surface features.}

Sorted nets: Central core of fines surrounded by narrow, nonvegetated border of rock fragments and developed commonly on both transported material $\left(\mathrm{N}_{\mathrm{T}}\right)(\mathrm{Fig} .20)$ and disintegrated bedrock $\left(N_{B}\right)$ (Fig. 21 ).

Nonsorted nets: Raised center, surrounded by depressed trench with nonsorted coarse material. Stone-centered nets ( $\mathrm{N}_{\mathrm{SN}}$ ) (Fig. 22) consist of rubbly lichen-covered central areas outlined by vegetation in the protected depressed borders. On slopes they elongate to form triangular islands of rock $\left(\mathrm{N}_{\mathrm{SS}}\right)$ (Fig. 23). The polygonal intergrade $\left(\mathrm{N}_{\mathrm{P}}\right)(\mathrm{Fig}$. 24) has a flat, raised center and a weakly defined polygonal shape.

Sorted polygons: Large polygonal-shaped, barren-covered gravelly center surrounded by a vegetated trough underlain by sorted gravels ( $\left.P_{S}\right)$ (Fig. 25).

Nonsorted, ice-wedge polygons: Completely vegetated polygons, surrounded by narrow troughs which are underlain by ice wedges $\left(W_{N}\right)$ (Fig. 26). Polygon edges may or may not be raised. Smaller, high-centered polygons are surrounded by deep, melt-out troughs both on flat terrain and slopes ( $W_{S}$ ) (Fig. 27).

Sorted circles: Small, commonly less than a meter across, circular mineral core surrounded by a mesh of sorted coarser boulders $\left(\mathrm{S}_{\mathrm{C}}\right)$ (Fig. 28).

Nonsorted circles: Considerable variation among types with many gradational forms.

Peat rings: Circular to oval wet mineral centers surrounded by ridge of peat or tussocks $\left(\mathrm{R}_{\mathrm{P}}\right)$ (Fig. 29).

Frost scars: Circular- to irregular-shaped exposures of mineral soil, usually covered by a network of desiccation cracks $\left(S_{F}\right)$ (Fig. 30). On slopes, they become triangular in shape with vegetated centers but no frontal lobe $\left(S_{F S}\right)$ (Fig. 31). 
Frost scar mound: Gradational form on slopes with welldefined raised center which is bare to completely vegetated $\left(\mathrm{S}_{\mathrm{M}}\right)$ (Fig. 32).

Inundated mounds: Raised, vegetated circular mounds underlain by either saturated mineral soil or peat and surrounded by wet marsh ( $\mathrm{MI}_{\mathrm{I}}$ ) (Fig. 33).

Nonsorted steps: Elongated, bare mineral centers with conspicuous vegetated frontal lobe and vegetated depressed lateral borders $\left(\mathrm{S}_{\mathrm{N}}\right)$ (Fig. 34).

Nonsorted stripes: Elongated stripes of bare soil with only weakly expressed frontal lobes $\left(\mathrm{S}_{\mathrm{S}}\right)$ (Fig. 35). On steep talus slopes, bare and lichen-covered stripes alternate $\left(S_{R}\right)$.

Solifluction mounds and terraces: This group constitutes many forms that do not lend themselves to grouping with other slope features. Common characteristics are: occurrence on wet slopes, conspicuous frontal lobe, bare mineral soil on upslope portion of feature, and folded under organic matter in both the seasonally thawed soil and perennially frozen zone $\left(\mathrm{S}_{\mathrm{T}}\right)$ (Fig. 36).

Hummocks: Relatively small, raised feature on flat and sloping terrain. Moss hummocks ( $\mathrm{H}_{\mathrm{M}}$ ) (Fig. 37) occur on steep, northfacing slopes. Peaty hummocks are zircular, tussock-like and have an organic core $\left(\mathrm{H}_{\mathrm{P}}\right)$ (Fig. 38). Irregular hummock nounds on slopes ( $\mathrm{H}_{\mathrm{PS}}$ ) (Fig. 39) are gradational to solifluction mounds.

Frost heaves:

Silt ooze: Small, triangular mineral spots distributed irregularly between tussocks and hummocks ( $\mathrm{H}_{\mathrm{S}}$ ) (Fig. 40).

Rubbly heaves: Mounds of fresh rubbly till recently heaved upward through a vegetated surface $\left(\mathrm{H}_{\mathrm{R}}\right)$ (Fig. 41).

Ice mounds: Ice-cored mounds along river terrace, resembling miniature pingos $\left(\mathrm{H}_{\mathrm{I}}\right.$ ) (Fig. 42).

Rock debris benches: Large mound-like features, crescentshaped in the downslope direction and composed of talus and colluvium ( $\mathrm{DB}_{\mathrm{B}}$ ) (Fig. 43).

Rubble pits: Pockets of rubble devoid of fines and vegetation on bouldery till (P) (Fig. 44).

Mudflows and slides: Large, continuous flows of saturated, thawed soil on slopes with high frontal lobes $\left(M_{F}\right)$ (Fig. 45). Bouldery slides occur on steep mountain and valley slopes $\left(M_{S}\right)$ (Fig. 46).

Strangmoor and peat ridges: Narrow, semi-continuous ridges of peat principally on wet river terraces $\left(\mathrm{S}_{\mathrm{G}}\right.$ ) (Fig. 47).

Levees: Parallel bouldery ridges adjacent to deeply gorged stream channels on alluvial-colluvial fans (L) (Fig. 48).

Trails: Caribou and sheep trails criss-cross the entire landscape at close intervals ( $\mathrm{T}$ ) (Fig. 49). In the mountains, trails are marked by upturned exposed rocks in contrast to more stable lichen-covered rock. 


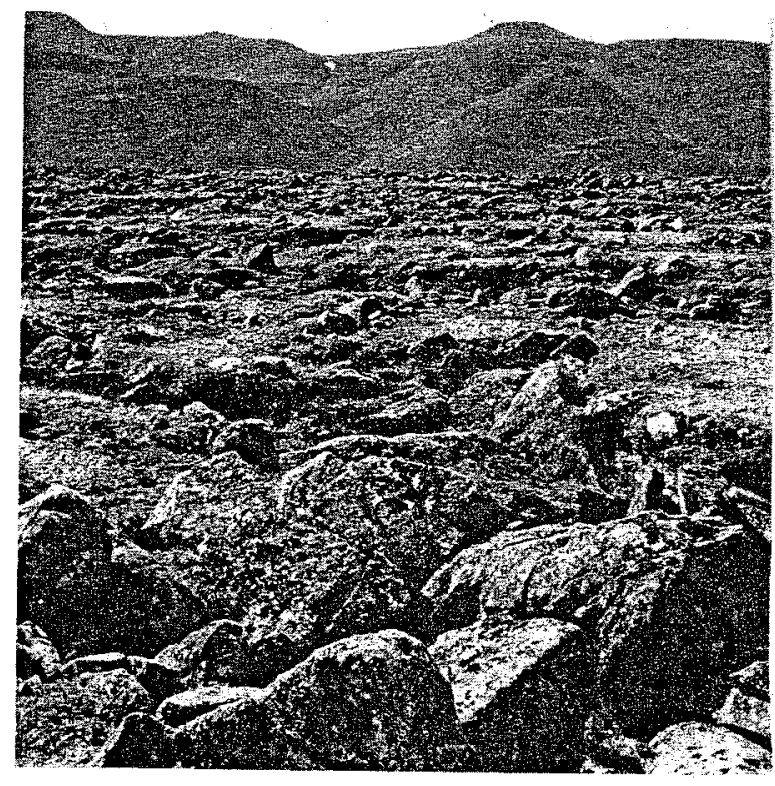

Figure 20. Sorted nets on lateral moraine $\left(\mathrm{N}_{\mathrm{T}}\right)$.

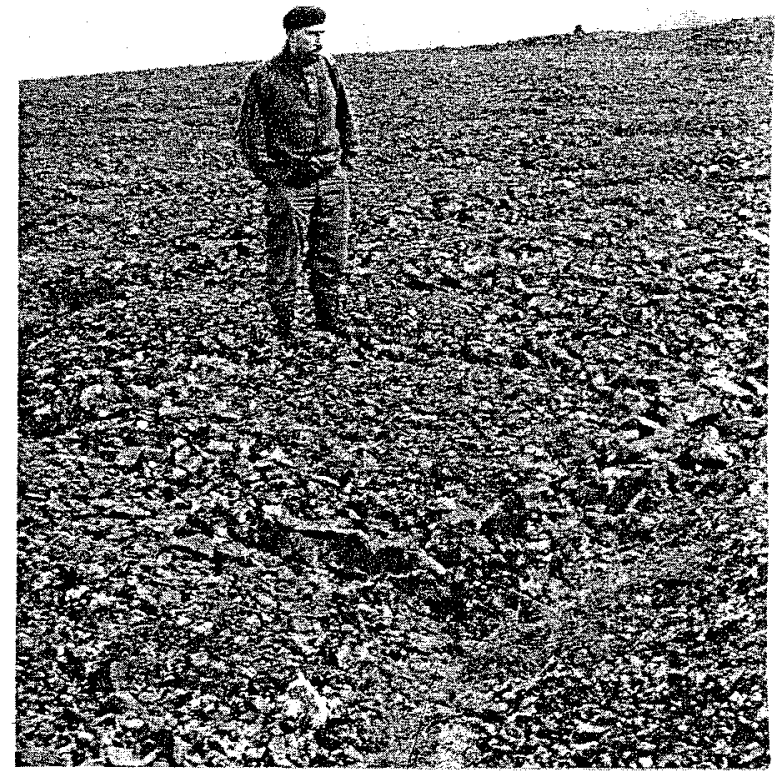

Figure 21. Sorted nets on flat bedrock terrace $\left(\mathrm{N}_{\mathrm{B}}\right)$.

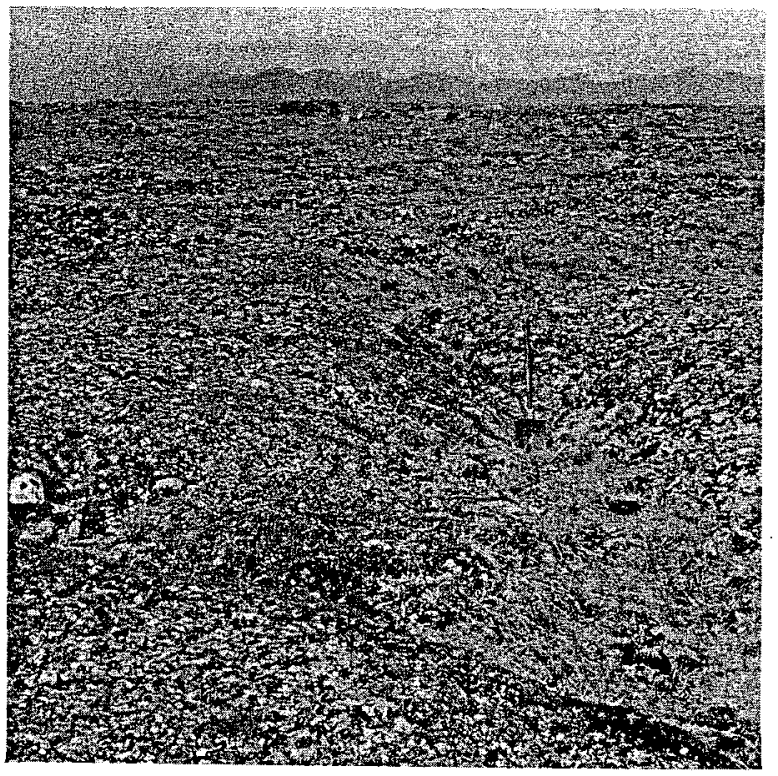

Figure 22. Nonsorted, stone-centered nets $\left(\mathrm{N}_{\mathrm{SN}}\right)$.

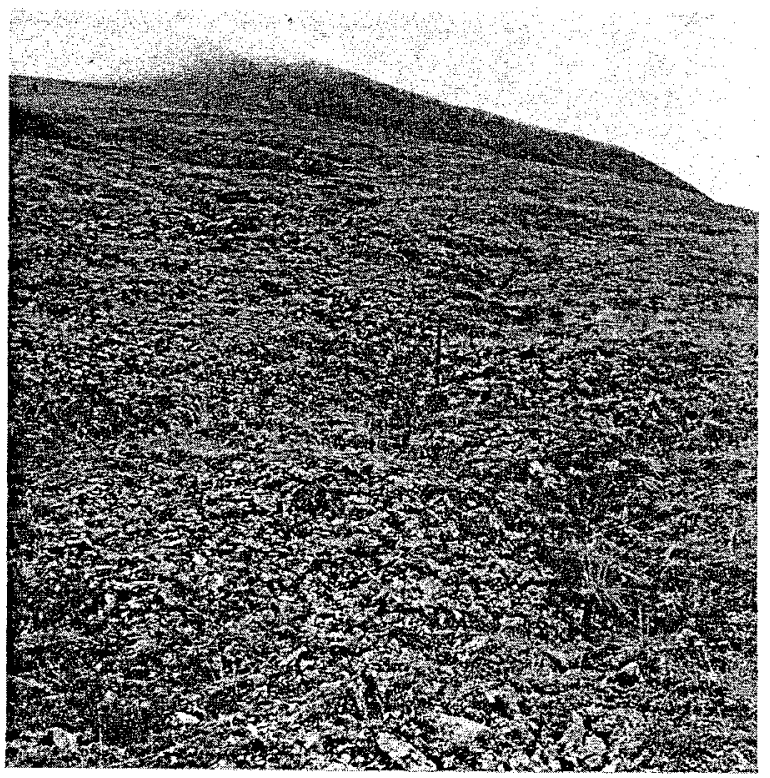

Figure 23. Nonsorted, stone-centered nets on slope (NSS). 


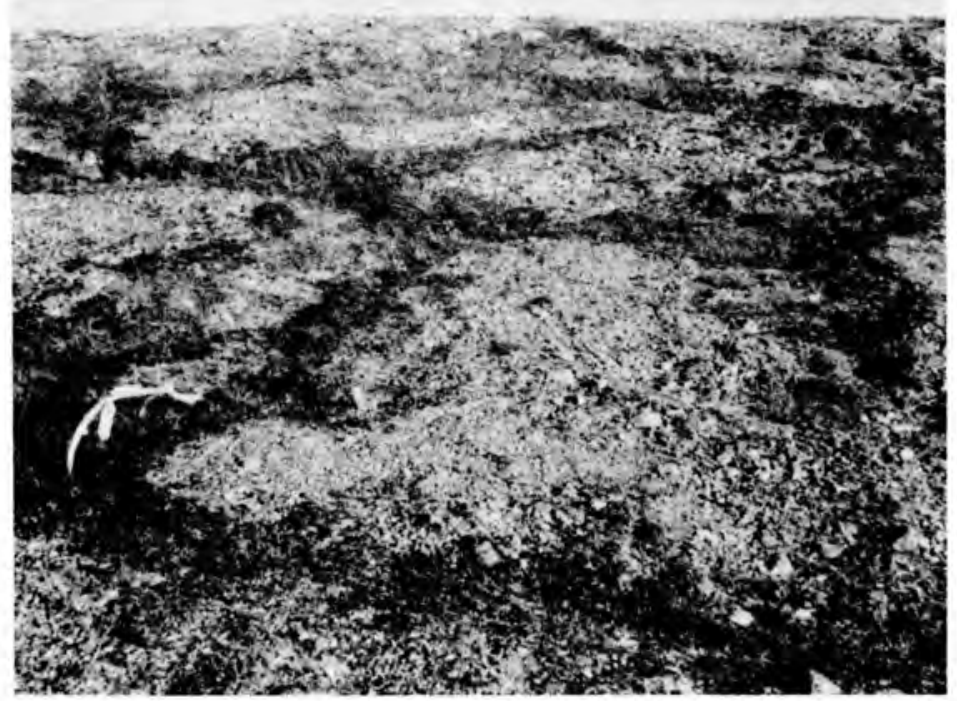

Figure 24. Nonsorted nets, polygonal intergrade $\left(N_{P}\right)$.

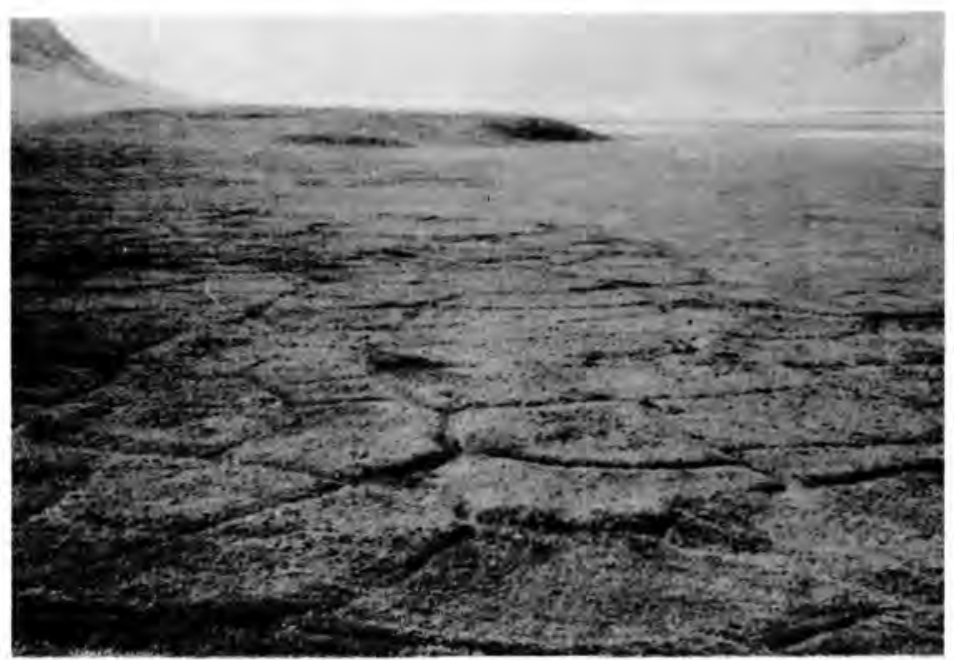

Figure 26. Nónsorted ice-wedge polygons $\left(W_{N}\right)$.

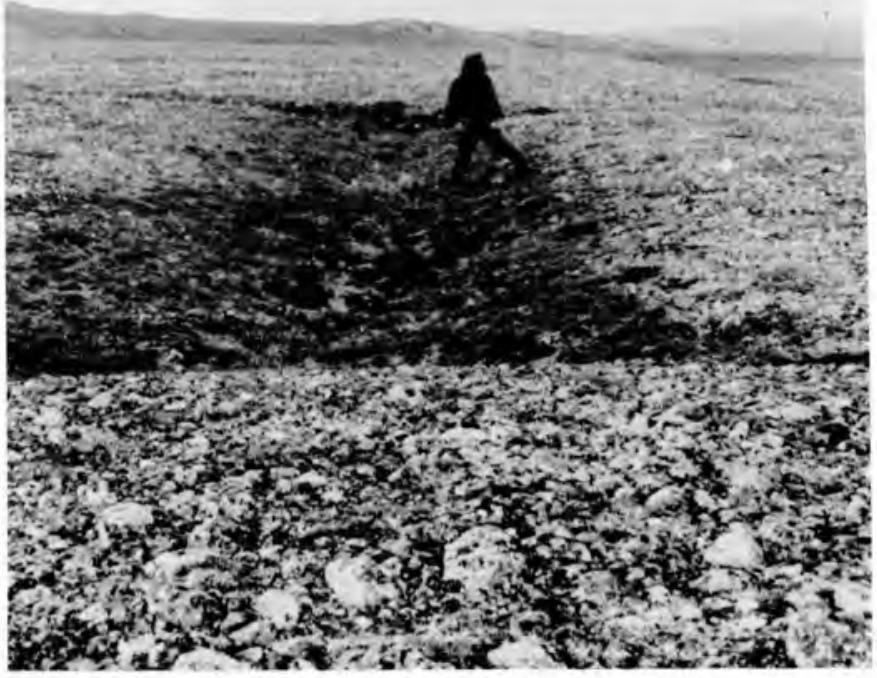

Figure 25. Sorted polygon $\left(\mathrm{P}_{\mathrm{S}}\right)$.

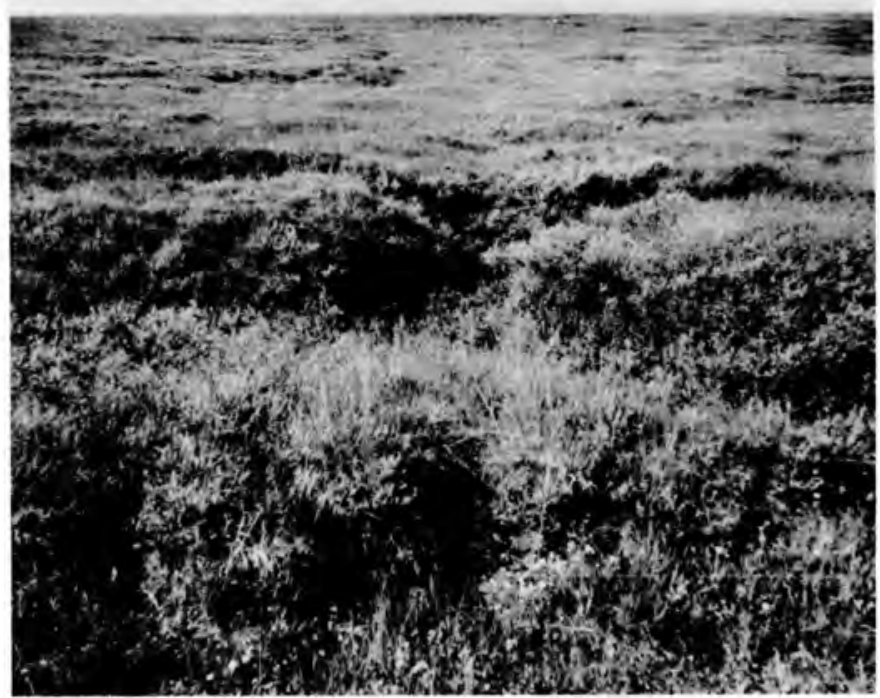

Figure 27. Nonsorted ice-wedge polygons on slope ( $\left.W_{S}\right)$, high-centered. 


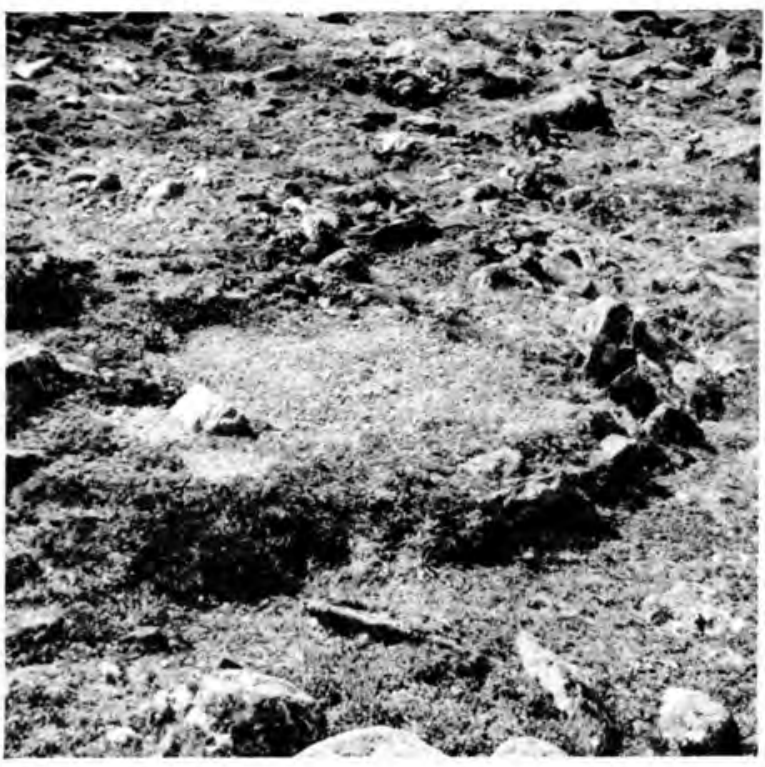

Figure 28. Sorted circles $\left(\mathrm{S}_{\mathrm{C}}\right)$.

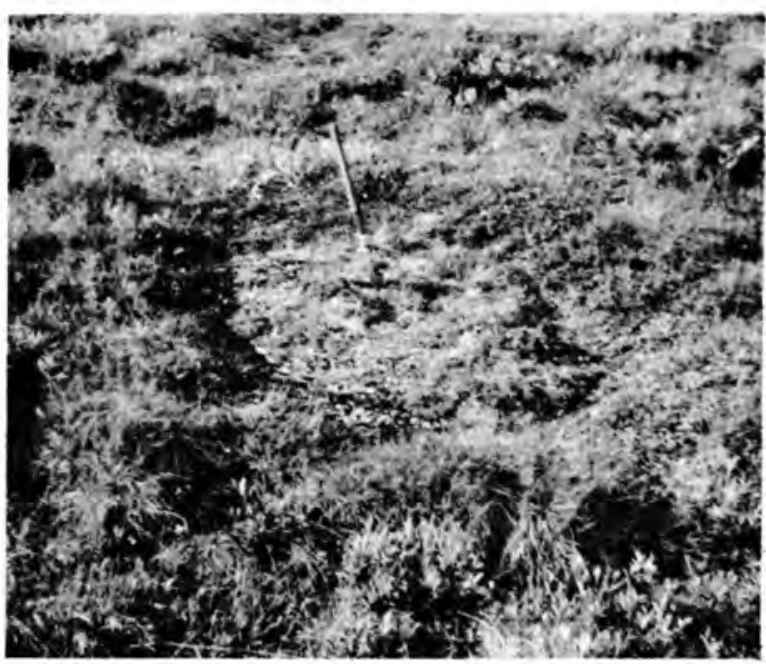

Figure 29. Nonsorted circle with raised peat ring $\left(R_{P}\right)$.

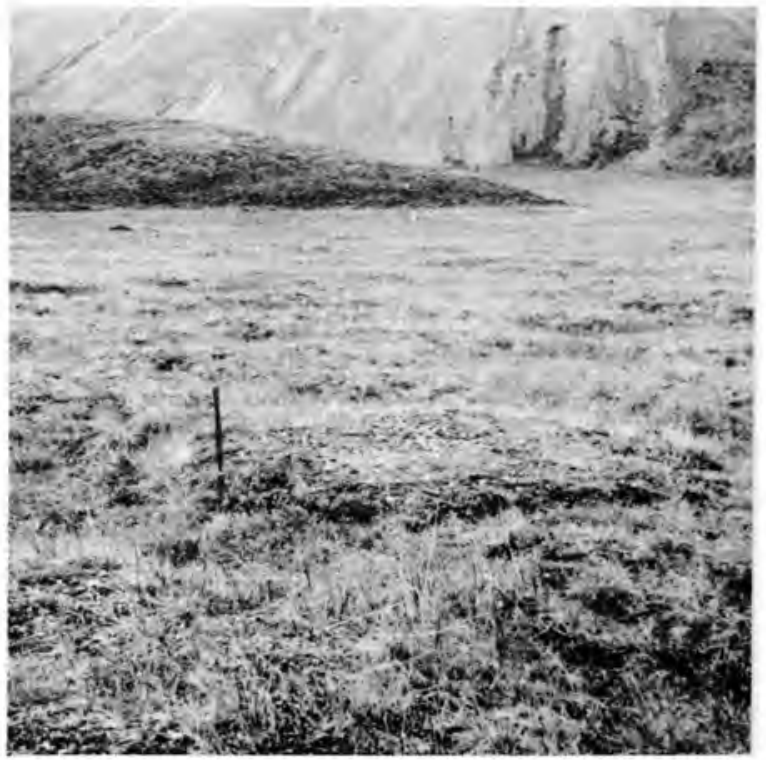

Figure 30. Nonsorted circle, frost scars $\left(\mathrm{S}_{\mathrm{F}}\right)$.

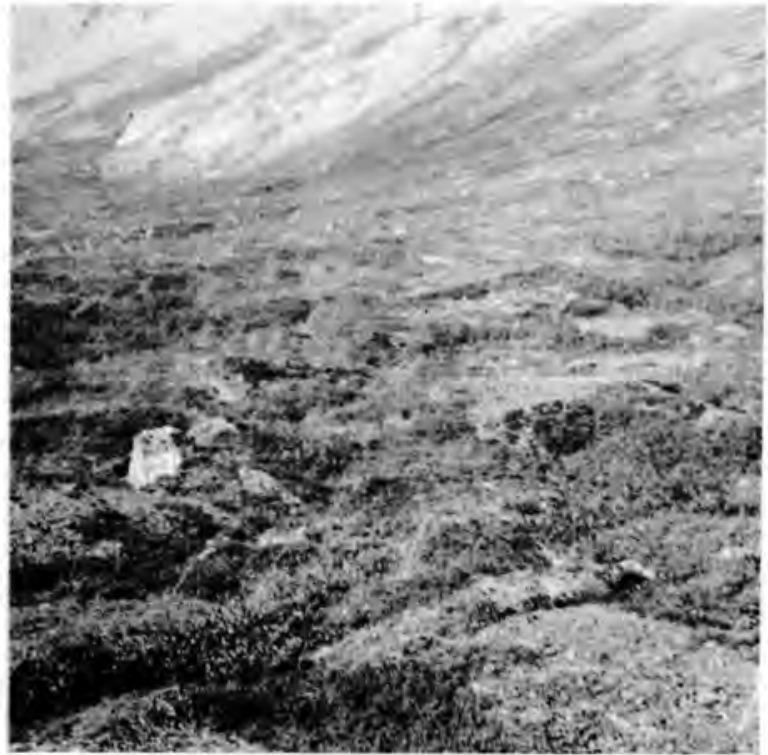

Figure 31. Nonsorted circle, frost scars on slope ( $\mathrm{S}_{\mathrm{FS}}$ ). 


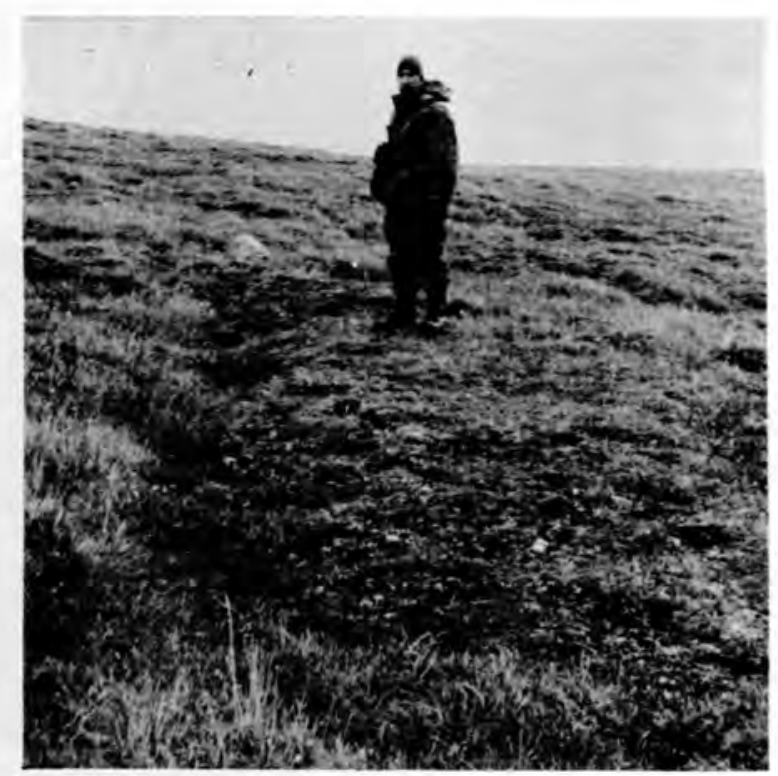

Figure 32. Nonsorted circle, frost scar mound on slope $\left(\mathrm{S}_{\mathrm{M}}\right)$.

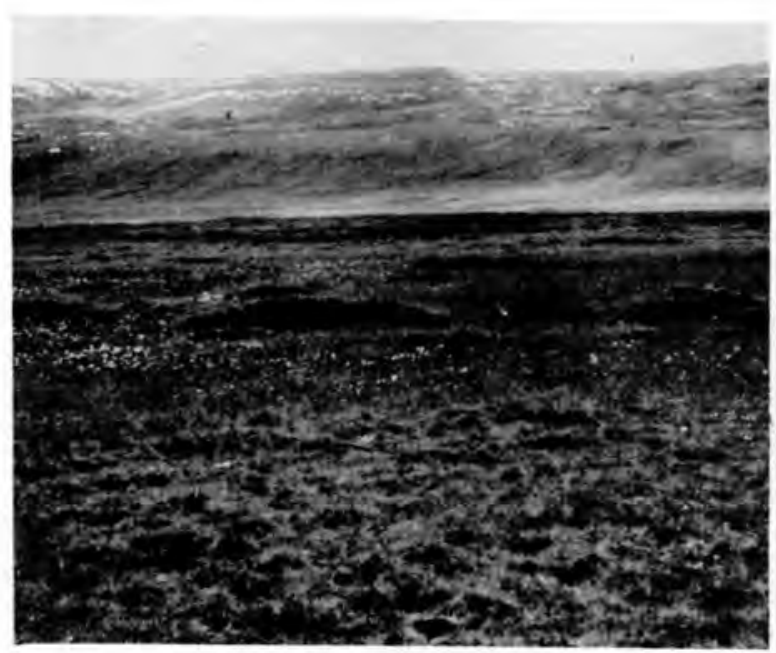

Figure 33. Nonsorted circle, inundated mounds $\left(\mathrm{M}_{\mathrm{I}}\right)$.

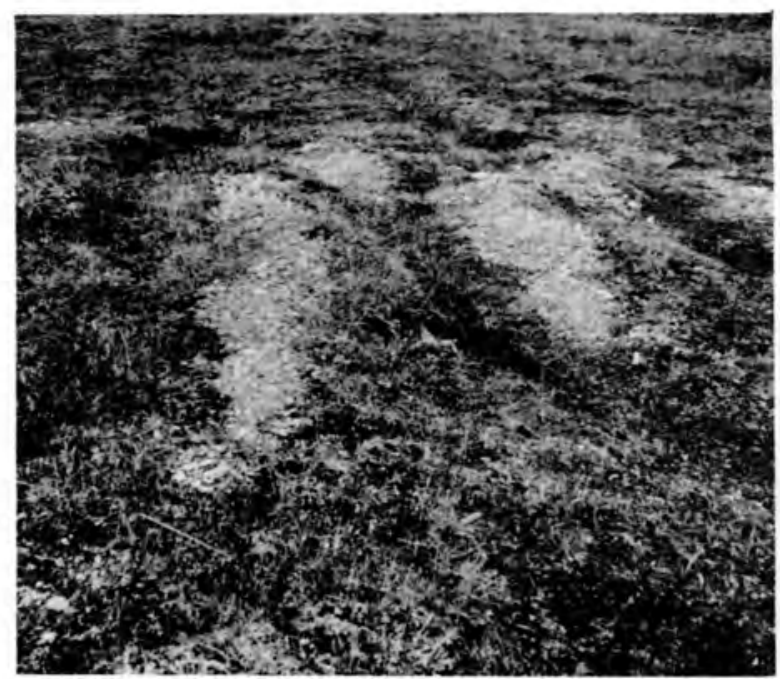

Figure 35. Nonsorted stripes $\left(\mathrm{S}_{\mathrm{S}}\right)$.

Figure 34. Nonsorted step $\left(\mathrm{S}_{\mathrm{N}}\right)$. 


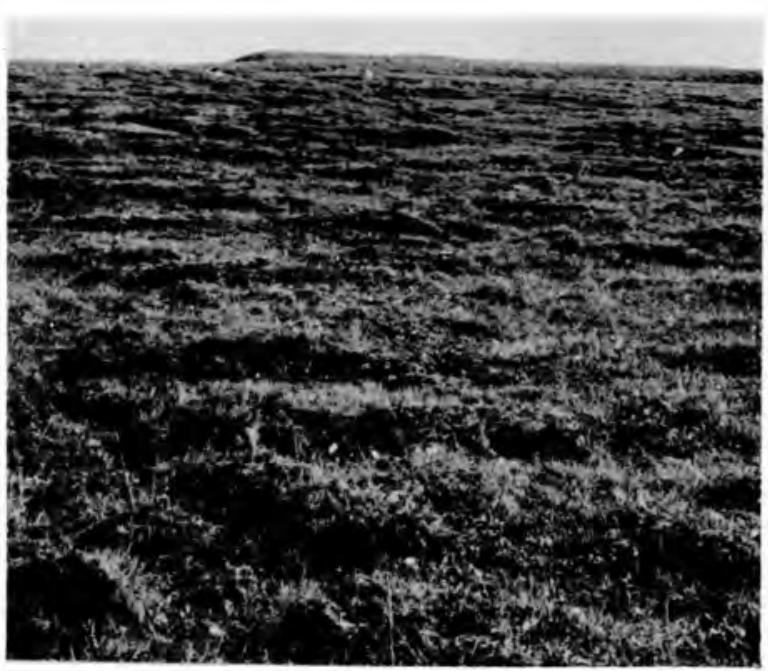

Figure 36. Solifluction terraces and mounds $\left(\mathrm{S}_{\mathrm{T}}\right)$.

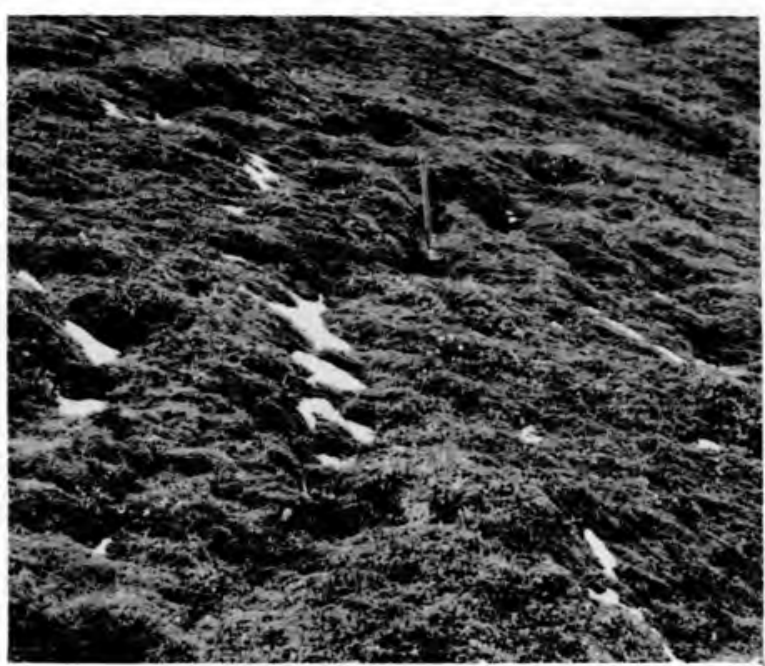

Figure 37. Hummocks, moss $\left(\mathrm{H}_{\mathrm{M}}\right)$.
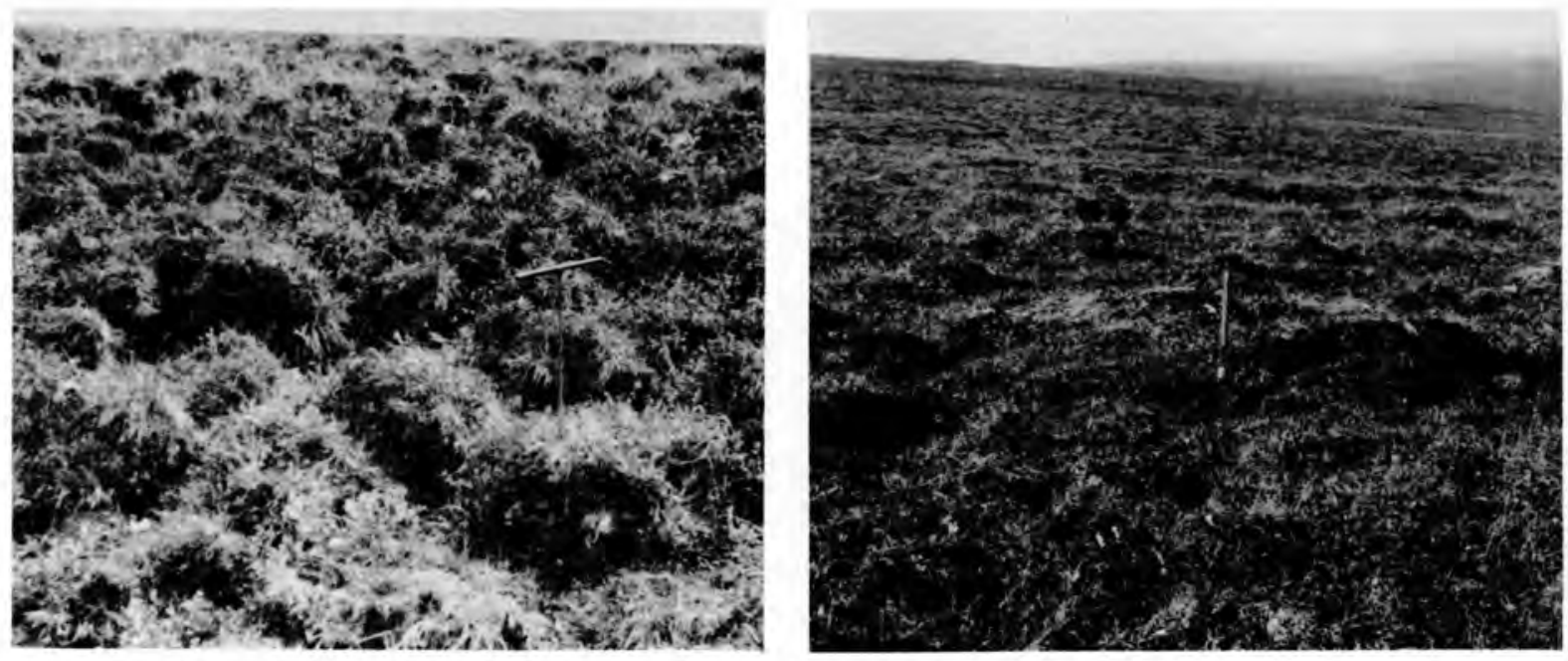

Figure 38. Hummocks, peaty mounds $\left(H_{P}\right)$. Figure 39. Hummocks, peaty mounds on slope ( $\left.\mathrm{H}_{\mathrm{PS}}\right)$. 


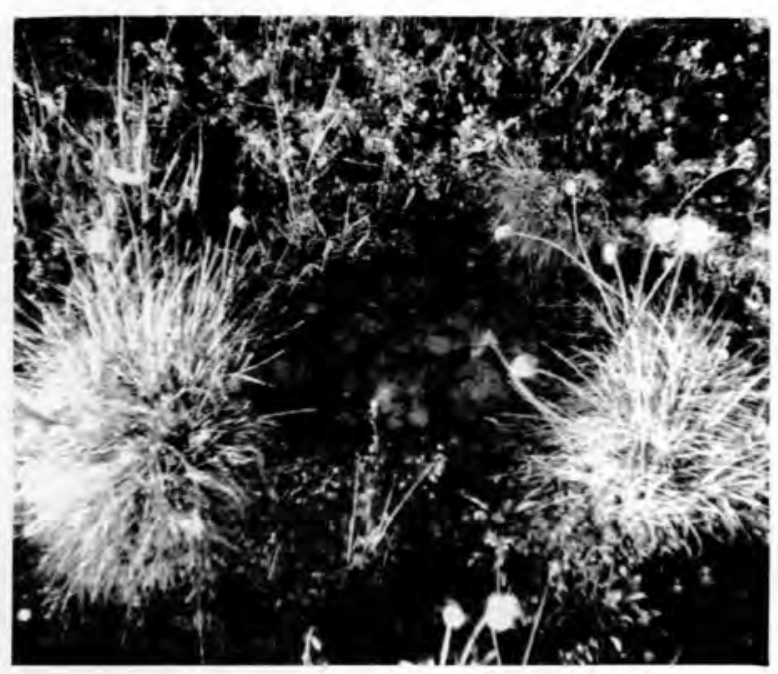

Figure 40. Frost heave, silt ooze $\left(\mathrm{H}_{\mathrm{S}}\right)$.

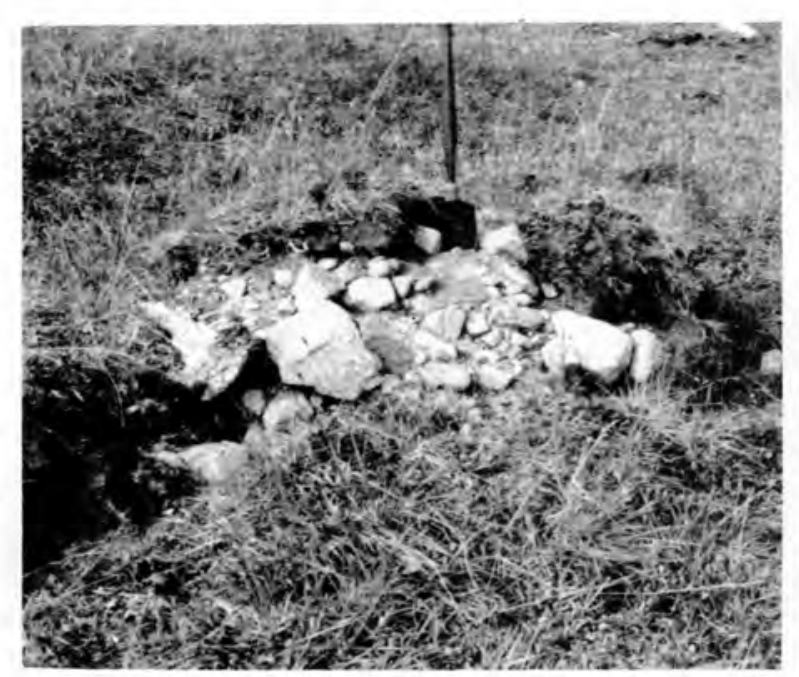

Figure 41. Frost heave, rubble $\left(\mathrm{H}_{\mathrm{R}}\right)$.

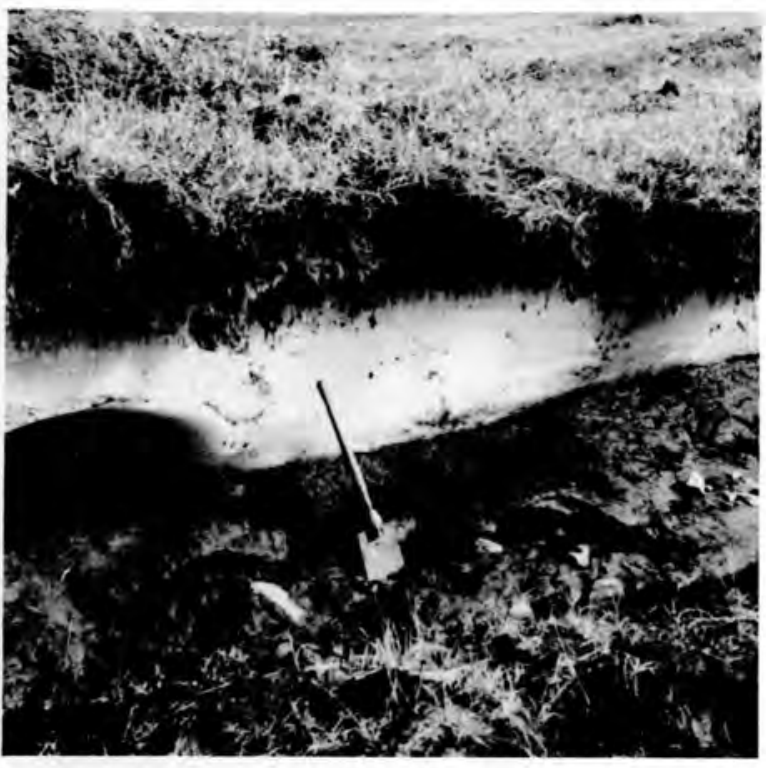

Figure 42. Frost heave, ice mound $\left(\mathrm{H}_{\mathrm{I}}\right)$.

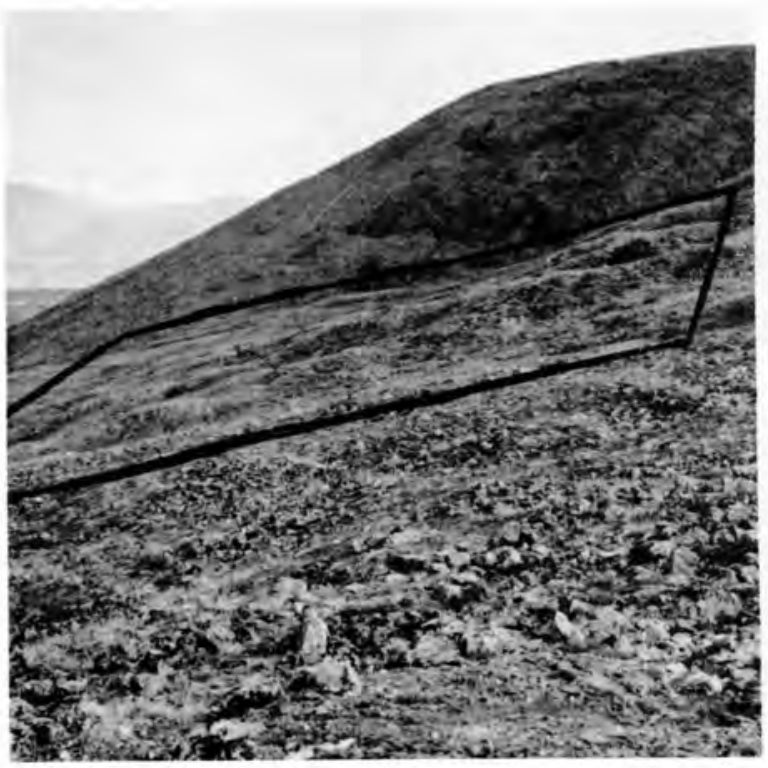

Figure 43. Rock debris benches $\left(D_{B}\right)$. 


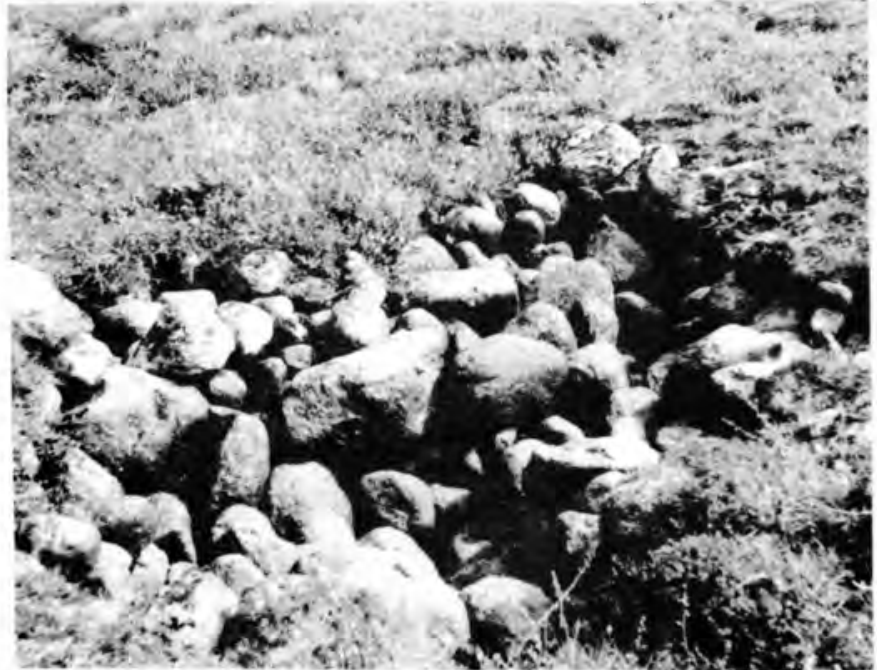

Figure 44. Rubble pit (P).

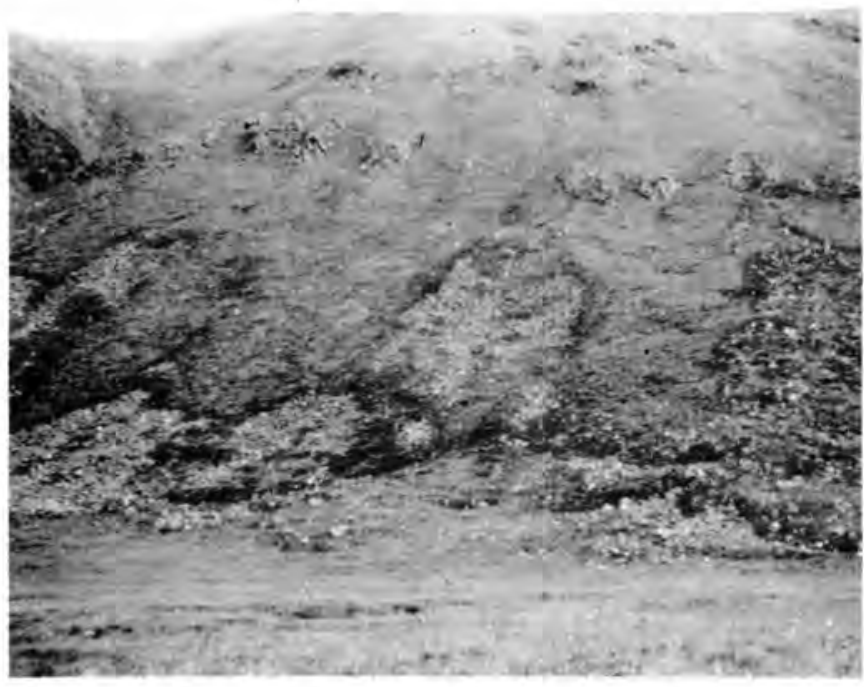

Figure 46. Rock slides $\left(\mathrm{M}_{\mathrm{S}}\right)$.

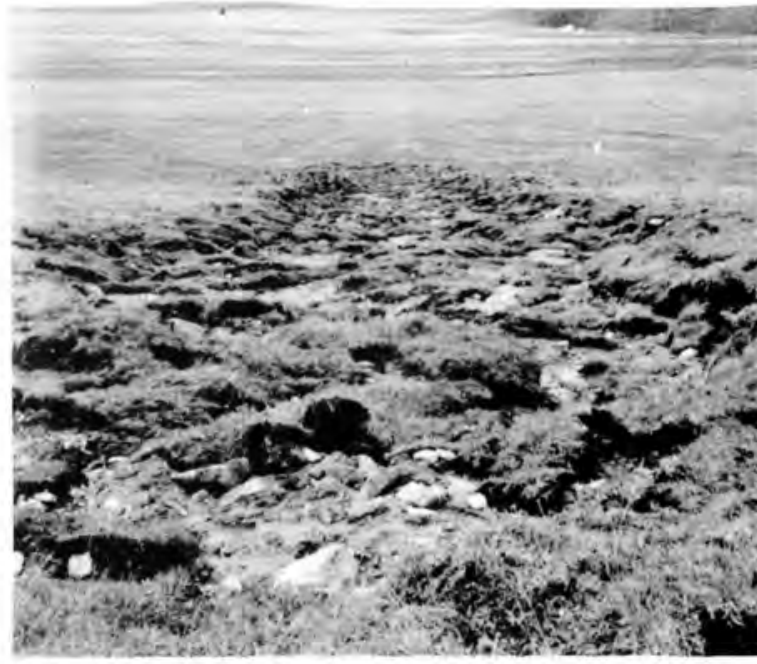

Figure 45. Mudflow $\left(M_{F}\right)$.

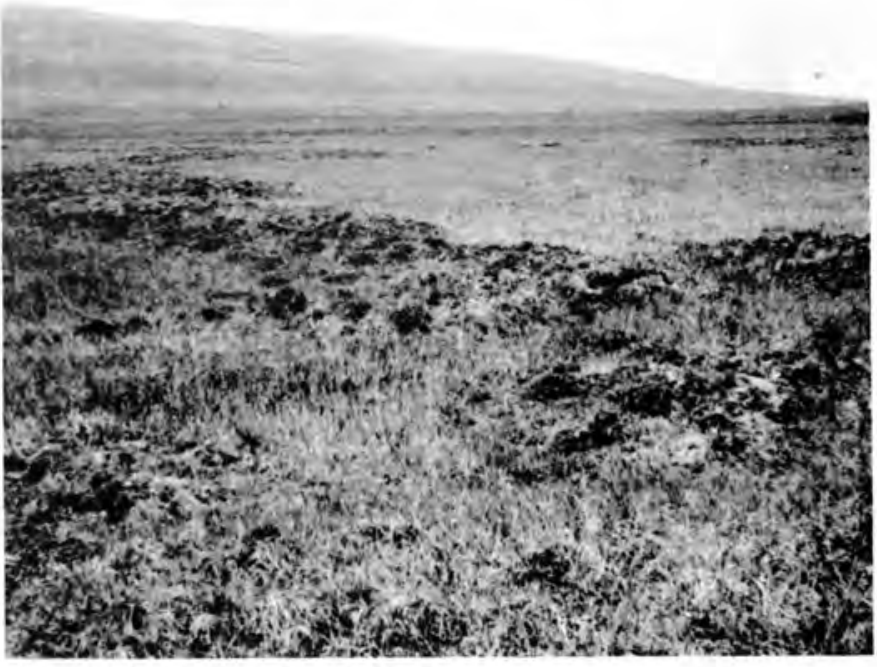

Figure 47. Strangmoor or peat ridge $\left(\mathrm{S}_{\mathrm{G}}\right)$. 


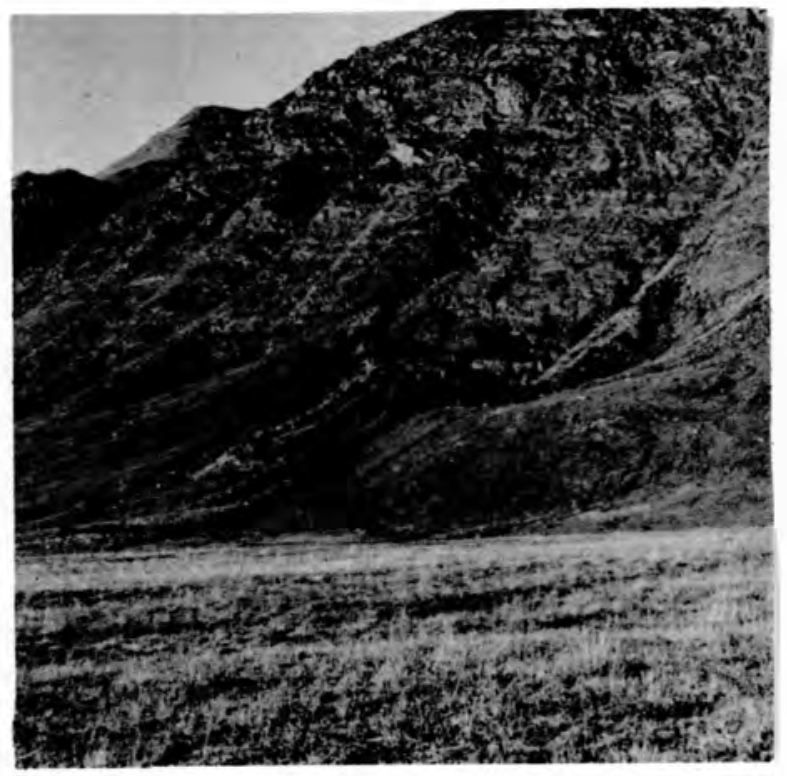

Figure 48. Levees (L).

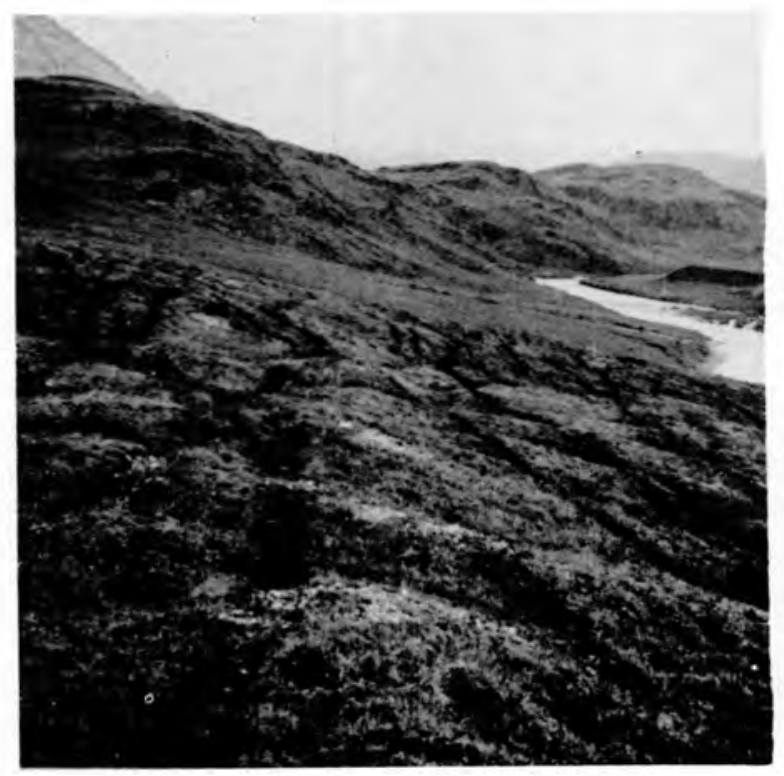

Figure 49. Trails (T). 


\section{Soils,*}

(01) Rockland - Slide rock, talus, felsenmeer and desert conditions with shallow to no soil development (Pfg. 3 ).

Mats and alluvial-colluvial substrata:

(10) Recent alluvium - Recently deposited, unweathered alluvium on flood plains and fans (Pfg. 3).

(11) Mat on rubble and bedrock - Thin partially humified organic mat on either glacial rubble devoid of fines or unshattered bedrock (Pfg. 3) (Fig. 50 and 51).

(12) Mat on well-drained substratum - Thin mat with organic matter in all stages of decomposition on well-drained, medium-textured mineral substratum with little evidence of further soil development; regosol intergrade. (Pfg. 3) (Fig. 52).

(13) Mat on poorly drained substratum - Wet peaty organic mat on a mottled gray substratum with little horizon differentiation and no flowing water; tundra intergrade (Pfg, 2).

(14) Stratified sediments - Distinct depositional layers of different-size mineral and organic materials as a result of deposition during frequent flooding (Pfg. 3) (Fig. 53).

Shallow soils on bedrock:

(20) Lithosols - Well +drained, loosely fragmented rock material with only faint color development under a discontinuous organic mat (Pfg. 3) (Fig. 54).

(21) Shallow arctic brown - Well-drained, coarse mineral material with thin, colored B-horizon on shattered or glacially scoured bedrock (Pfg. 3) (Fig. 55).

Shallow soils on transported materials:

(30) Regosol - Well-drained, predominantly sandy deposit with thin surface organic mat and virtually no horizon differentiation (Pfg. 3) (Fig. 56).

(31) Shallow a rctic brown - Well-drained soil with at least one distinct brown-colored horizon (Pfg. 3) (Fig. 57).

(32) Podzol-like soil - Well-drained soil with thin and frequently discontinuous gray, $\mathrm{A}_{2}$ - horizon over a brown B-horizon (Pfg. 3) (Fig. 58).

Moderately deep, well-drained soils:

(40) Normal arctic brown - Well-drained soil with three distinct, ideally equidimensional horizons $\left(\mathrm{A}_{1}-\mathrm{B}_{21}-\mathrm{B}_{22}\right)$ and usually formed
on transported parent materials (Pfg. 3$)^{21}$

(41) Arctic brown mull and humus carbonate - Well-drained soils with thick, well-humified, surface organic layer and frequently on calcareous substrata (Pfg. 3) (Fig. 59).

*Depth to perennially frozen ground (Pfg.)

Pfg. 1 - Shallow, approximately $30 \mathrm{~cm}$.

Pfg. 2 - Moderate, approximately $60 \mathrm{~cm}$.

Pfg. 3 - Deep, generally greater than $90 \mathrm{~cm}$.

Pfg. 4 - Irregular, undulating and generally between 30 and $90 \mathrm{~cm}$. 
Tundra soils on wet mineral substrata:

(50) Raw tundra - Imperfectly drained, olive-brown soil with conspicuous vesicular structure and no surface vegetation (Pfg. 4) (Eig. 60).

(51) Upland tundra - Imperfectly drained, mottled, mineral soil usually with some buried organic matter (Pfg. 2) (Fig. 61).

(52) Inundated tundra - Water-saturated mineral soil with thin, wet surface peat on flat river terraces (Pfg. 4) (Fig. 62).

(53) Meadow tundra - Wet gray mineral soil with characteristic cottongrass-tussock vegetation and mat (Pfg. 1).

(54) Organo-mineral tundra - Water-saturated profile with characteristic horizon composed of a mixture of finely disseminated organic material and silts with flowing water. Little mottling (Pfg. 2) (Fig. 63).

(60) Soils of the solifluction slope - No distinct, single soil profile, but a combination of characteristics such as buried organic matter, water saturated mineral soil, unstable surface conditions (Pfg. 4) (Fig. 4, 5, 6).

Organic soils:

(70) Sod peat - Thick, fibrous, tightly matted peat associated with flowing water on flats and slopes (Pfg. 2) (Fig. 64).

(71) Moss peat - Accumulation of predominantly mossy plant fragments on polygonal ground and gentle slopes (Pfg. 1) (Fig. 65).

(72) High moss peat - Mossy peat layer on loose talus or perennially frozen substratum at higher altitudes and no flowing water present (Pfg. 4) (Fig. 66).

(73) Dry peat - Dry, fibrous and woody peat generally on top of high-centered polygons (Pfg. 1) (Fig. 67).

(74) Bog - Thick, water-saturated, sedgy organic deposits along terrace bows and lake shores (Pfg, 3) (Fig. 68). 


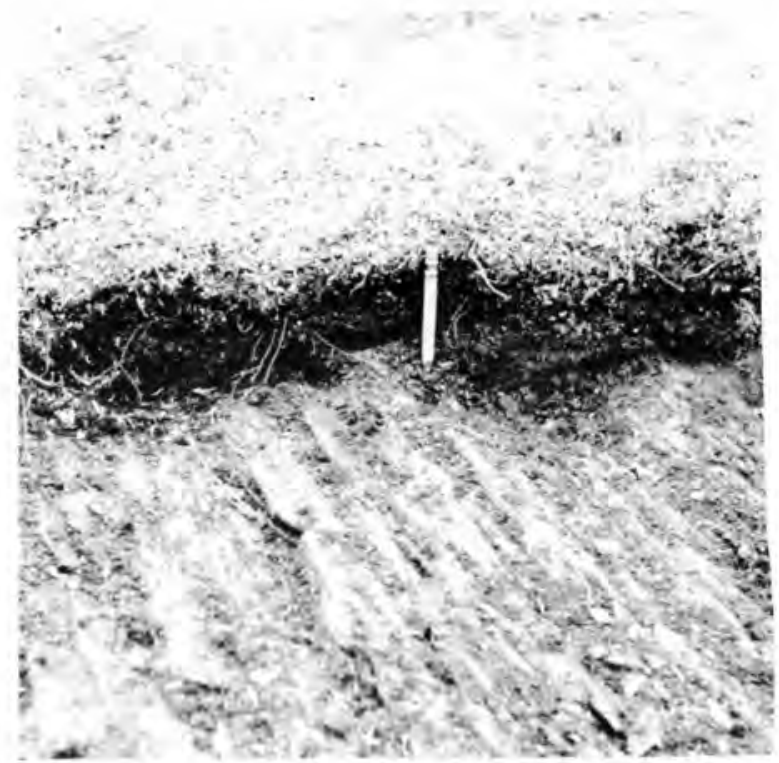

Figure 50. Mat on bedrock (I l).

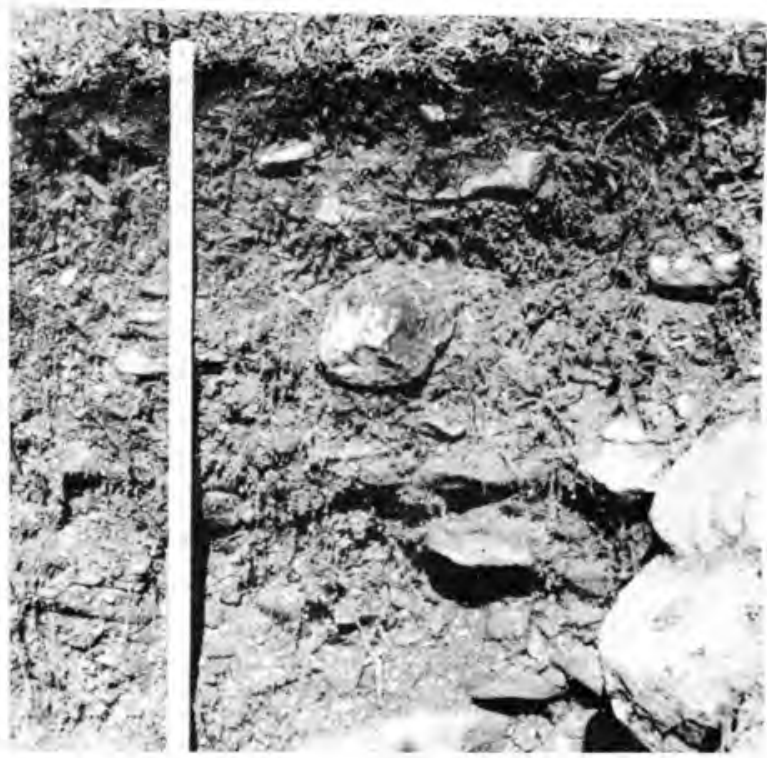

Figure 52. Mat on well-drained substratum, regosol intergrade (12).

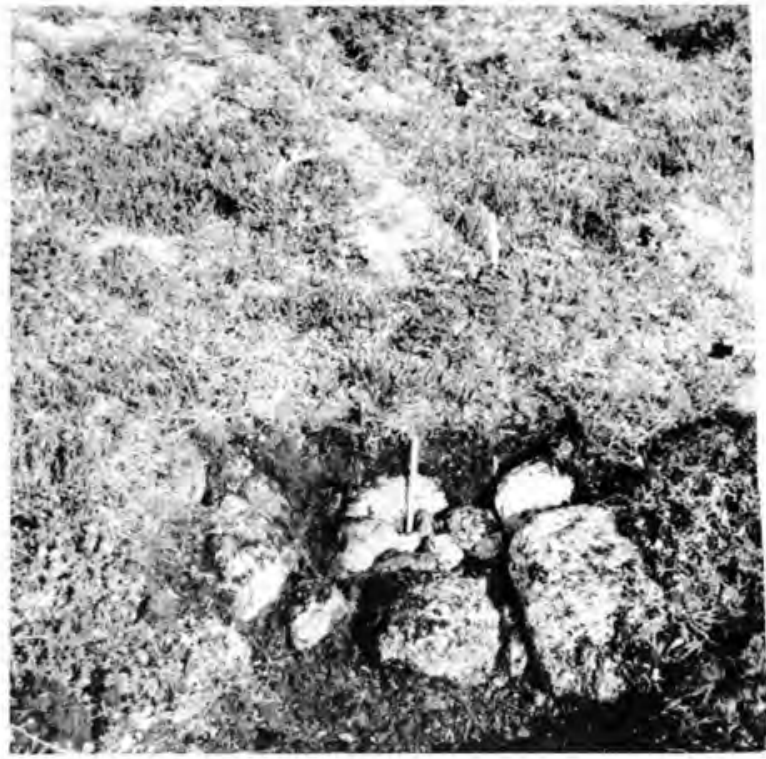

Figure 51. Mat on rubble (11).

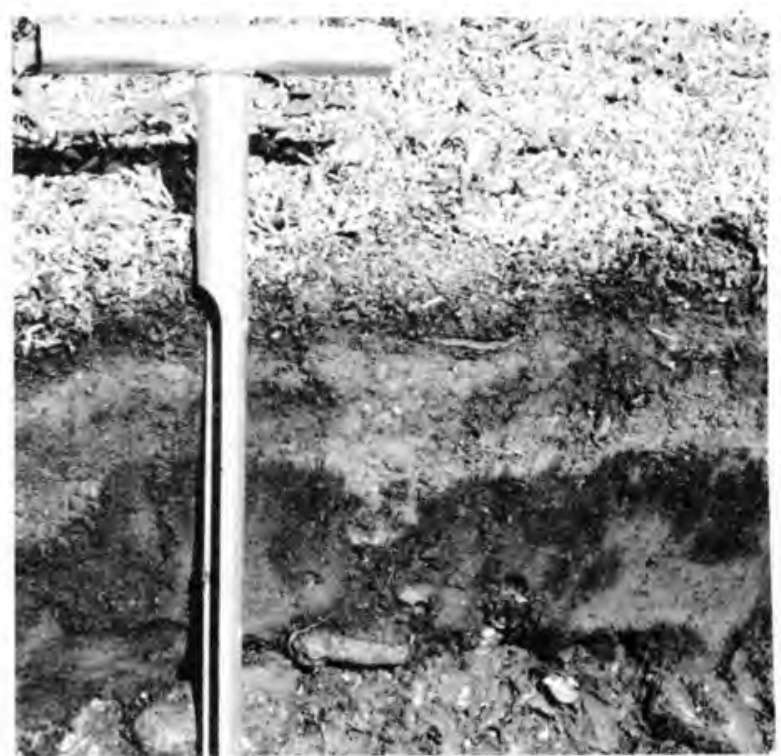

Figure 53. Stratified soil (14). 


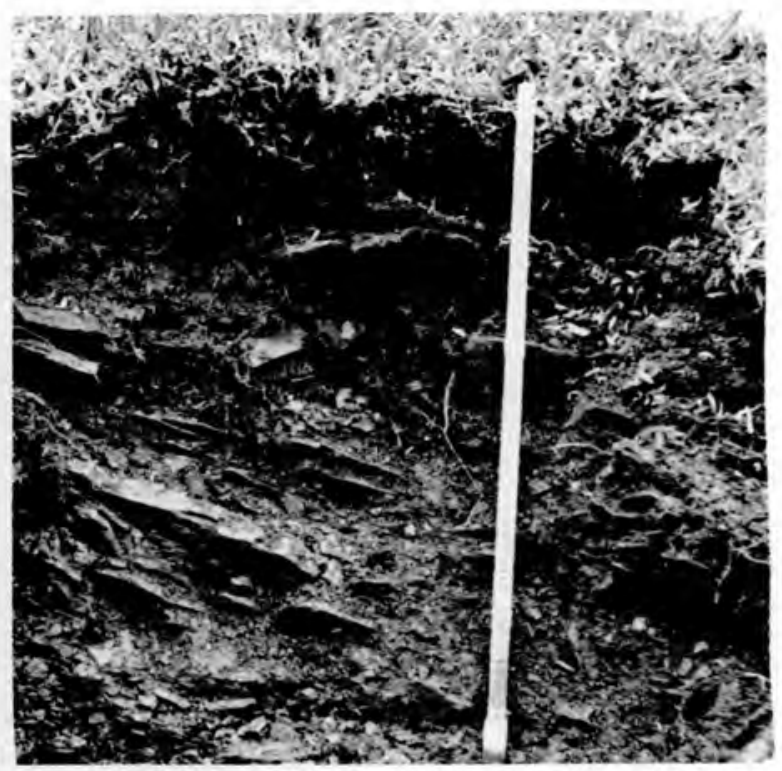

Figure 54. Lithosol on bedrock (20).

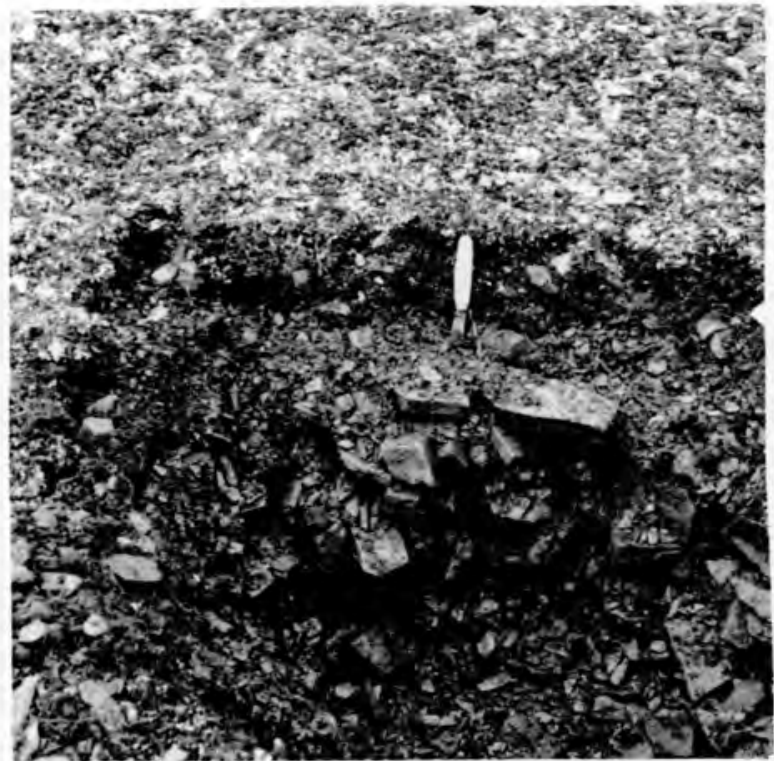

Figure 55. Shallow arctic brown on bedrock (21).

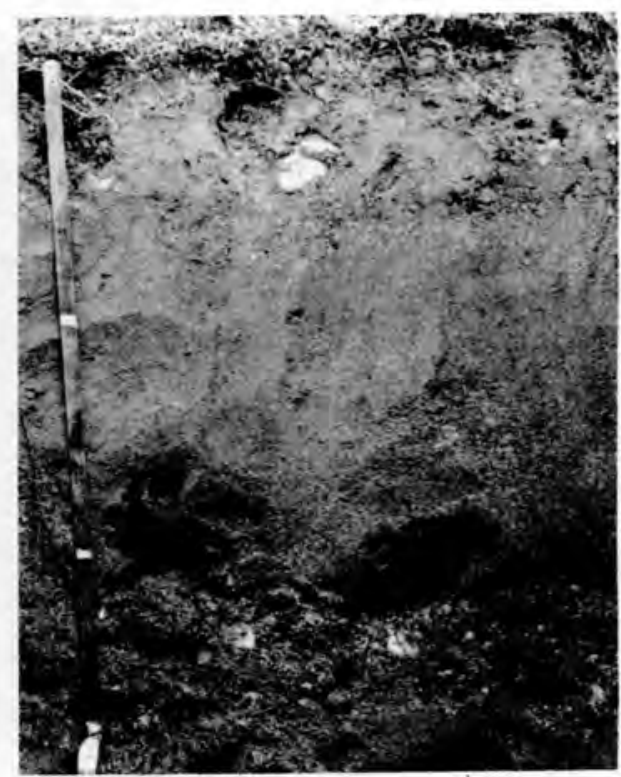

Figure 56. Regosol (30).

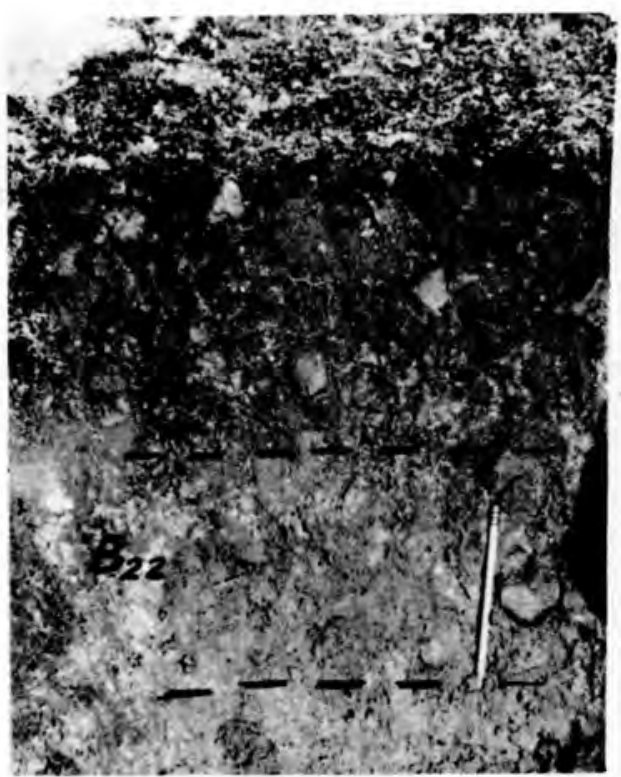

Figure 57. Shallow arctic brown on alluvium (31). 


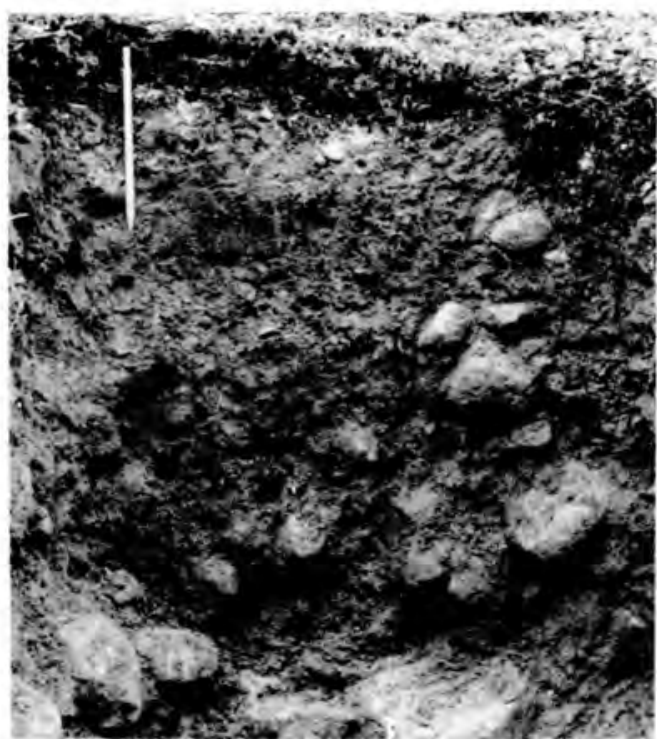

Figure 58. Podzol-like soil on till (32).

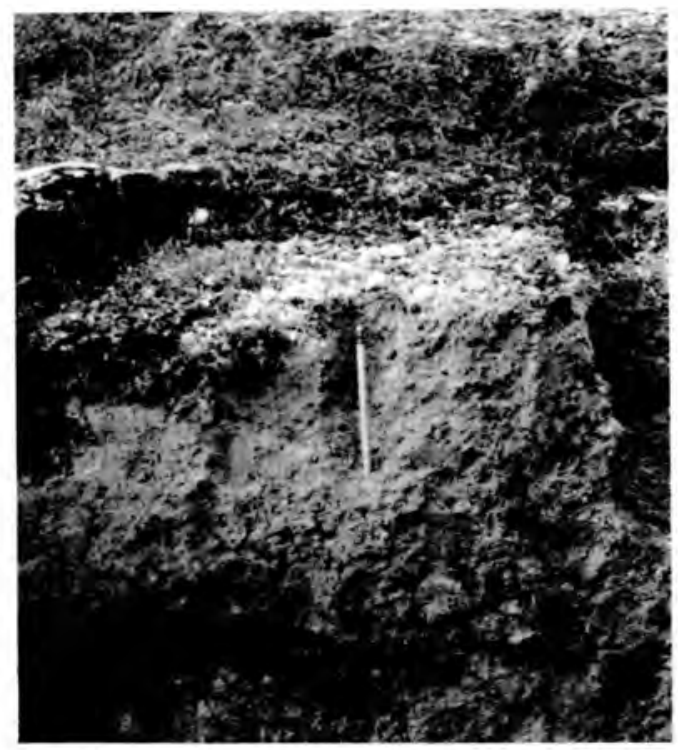

Figure 60. Raw tundra with vesicular structure (50).
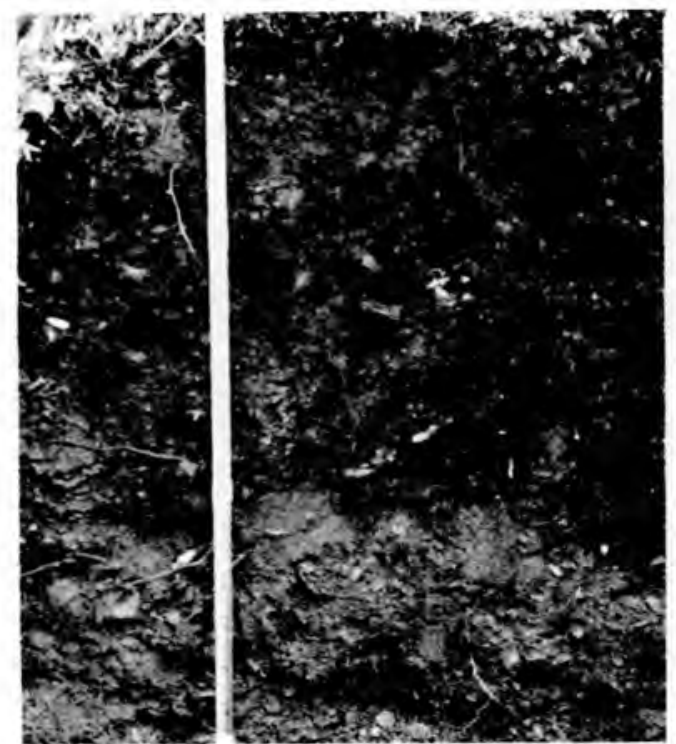

Figure 59. Arctic brown mull (41).

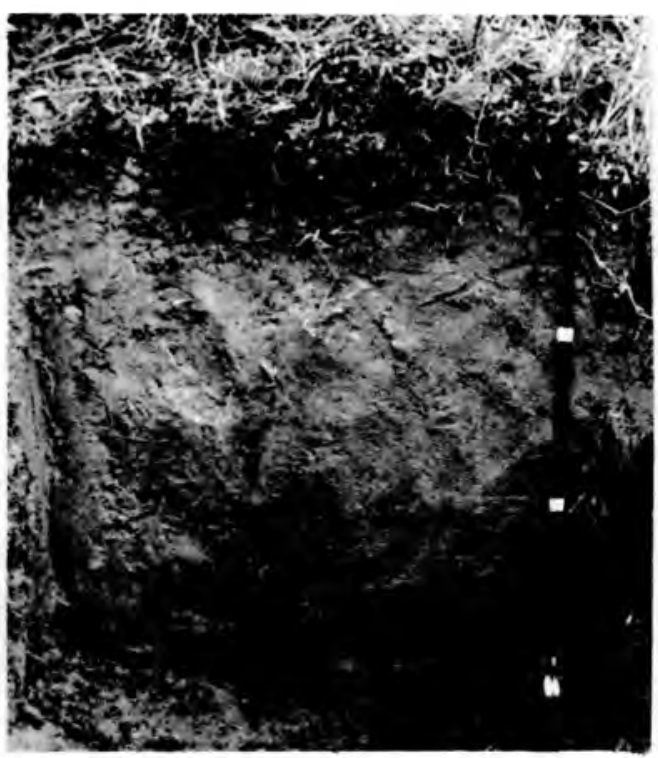

Figure 61. Upland tundra (51). 

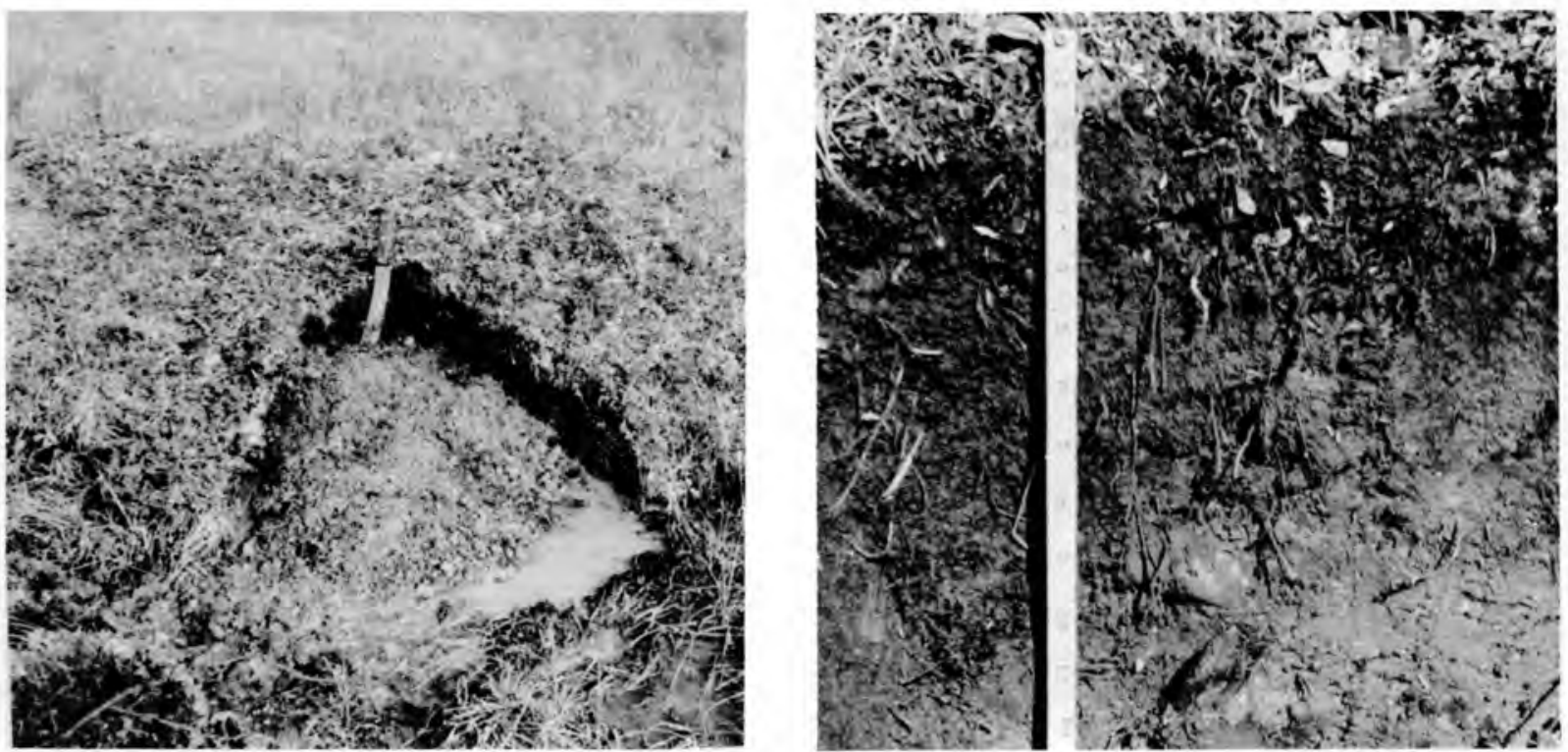

Figure 62. Inundated tundra (52).

Figure 63. Organo-mineral tundra (54).

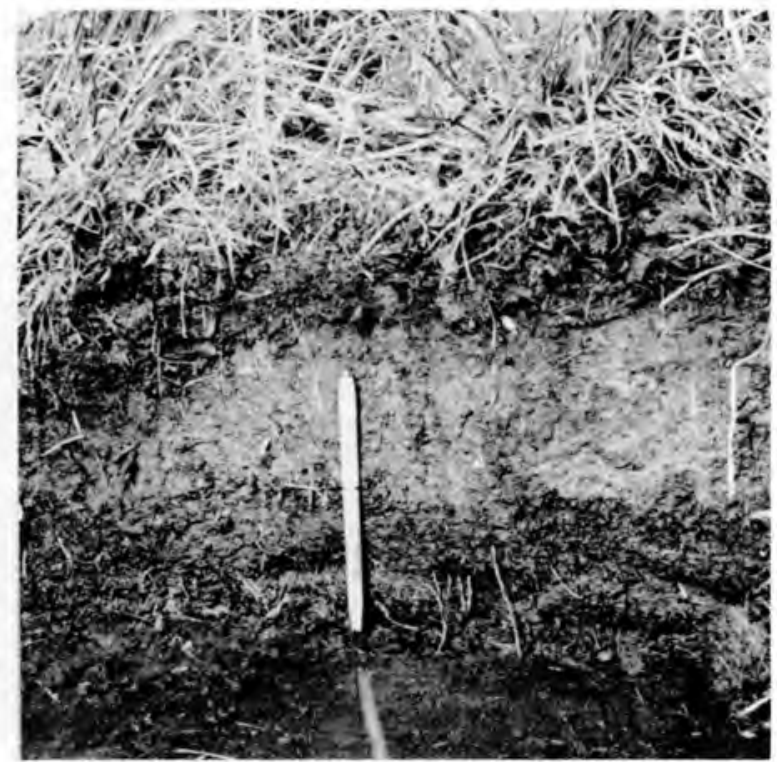

Figure 64. Sod peat (70).

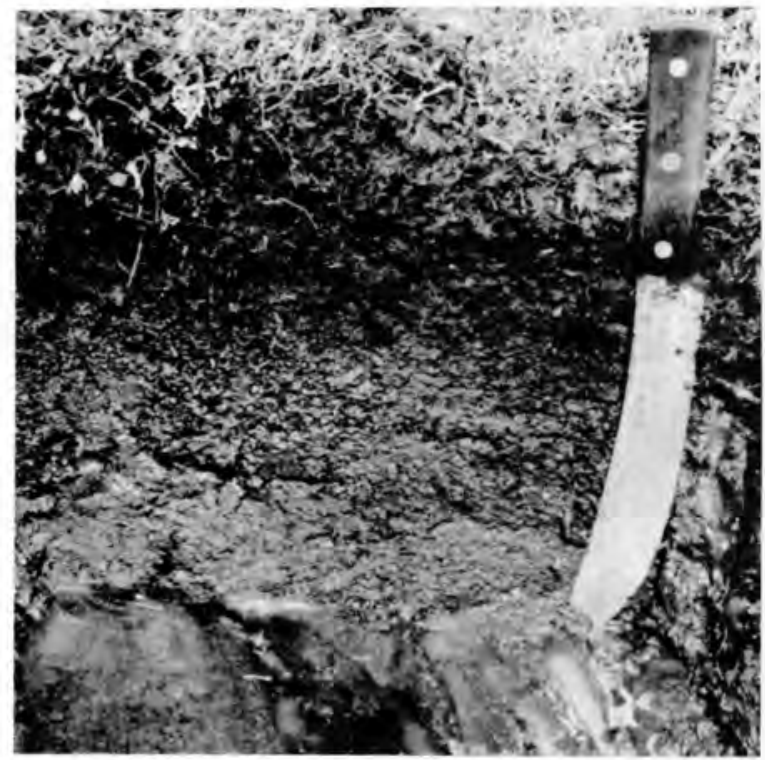

Figure 65. Moss peat (71). 

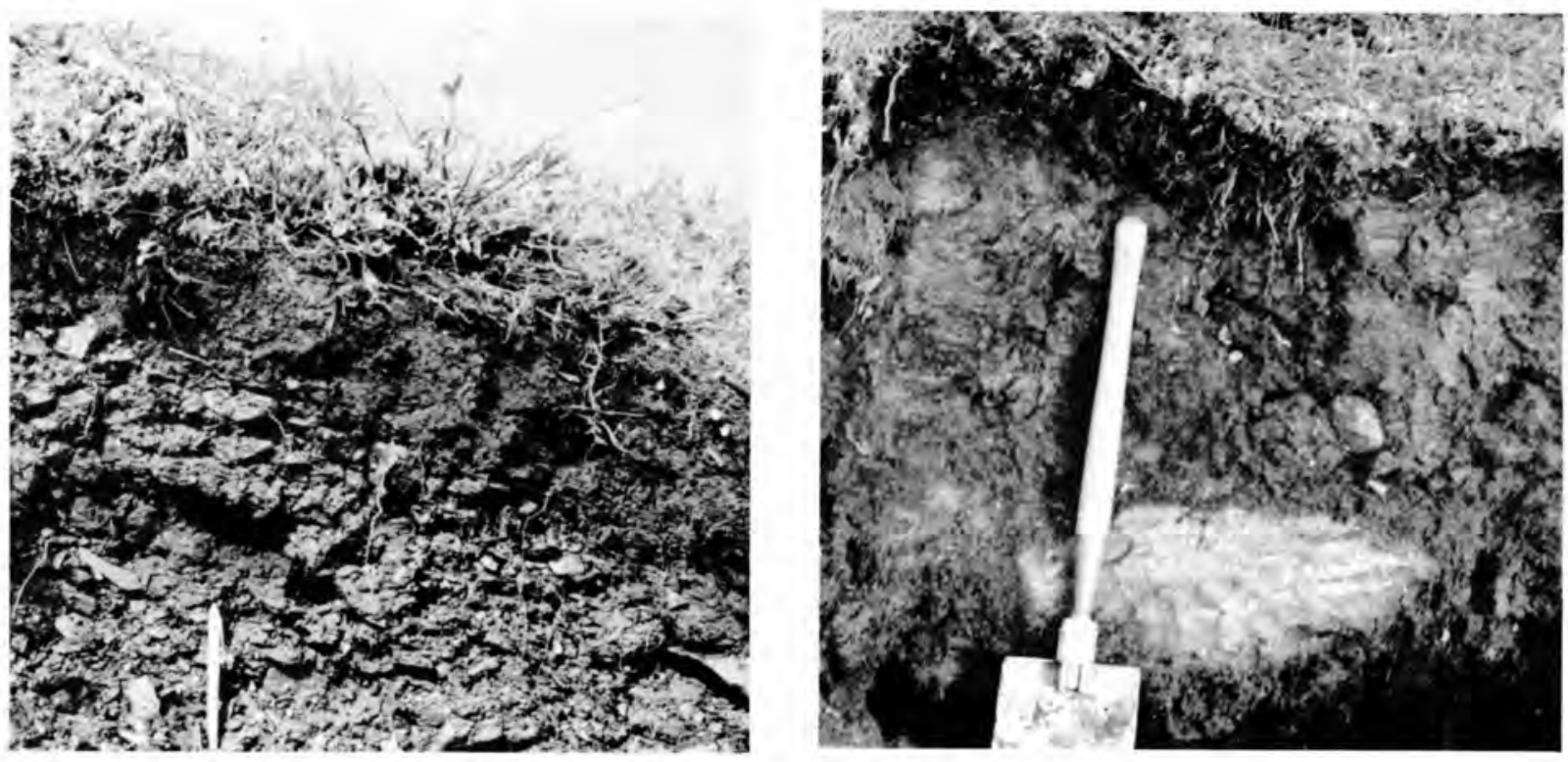

Figure 66. High moss peat, shallow (72). Figure 67. Dry peat with ice and cobble inclusions (73).

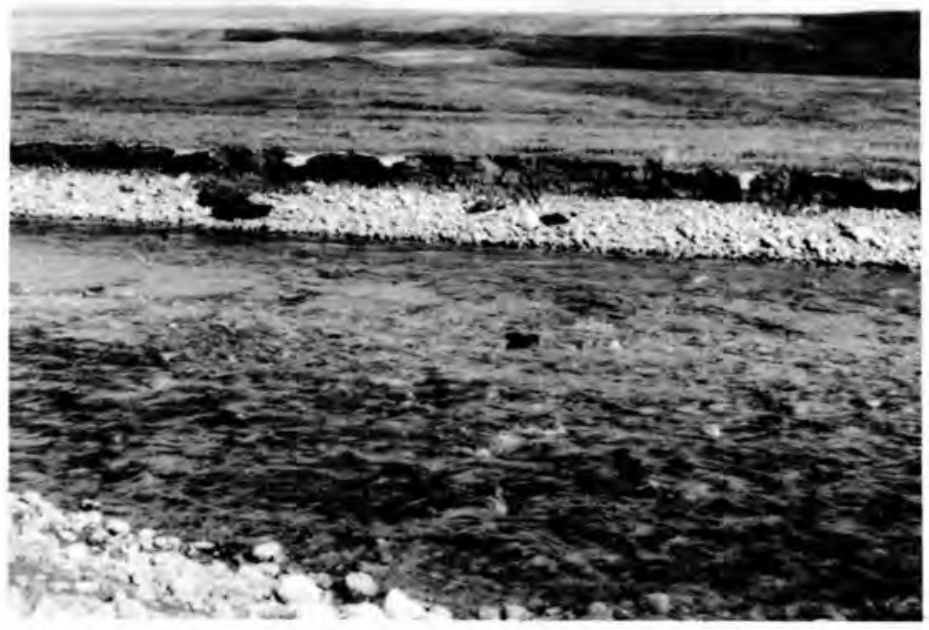

Figure 68. Bog peat along river terrace (74). 


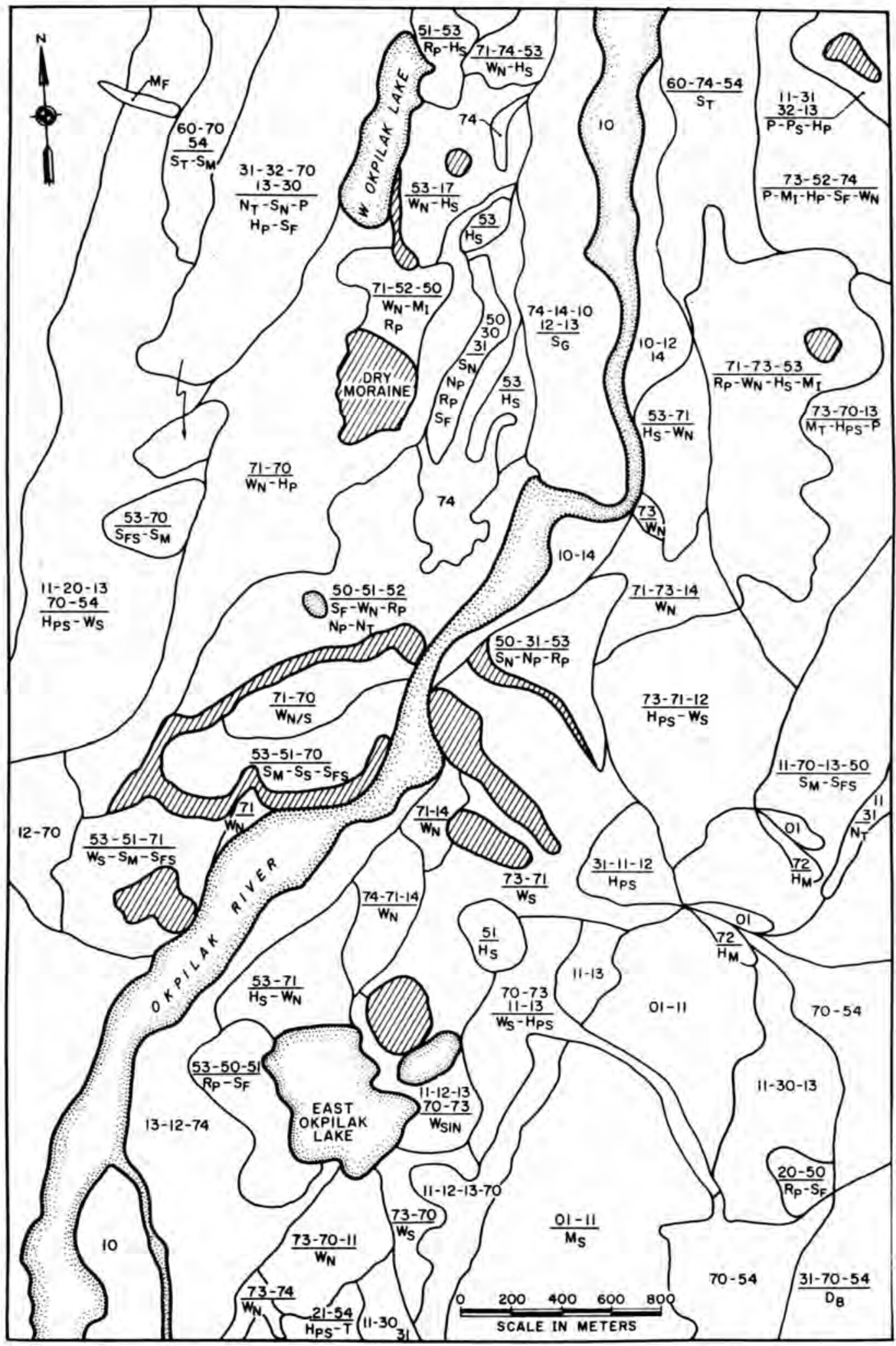

Figure 69. Map of soils and patterned ground in the vicinity of the Okpilak lakes. 


\section{PART III. SOIL FORMING PROCESSES}

The well-drained soils

Investigation of the relatively stable, well-drained soil site often demonstrates the significance of one or more of the classical factors of soil formation. The glacial geology of the Brooks Range and southern Foothills, and particularly of the Okpilak Valley, provided an excellent opportunity for evaluating the influences of time and parent material upon soil development. Within a distance of some $45 \mathrm{~km}$ in the Okpilak Valley evidences of numerous glacial advances are present. Both the age and composition of the glacial and glacio-fluvial deposits change along this north-south transect. In addition to this traverse, in which the factors of time and parent material were evaluated, studies were conducted to evaluate the changes in the well-drained soils with increasing altitudes. In this vertical direction, the climate was considered to be the primary variable. Numerous welldrained soil profiles were described and sampled across these vertical and longitudinal traverses for not only the Okpilak River region, but also the Lakes Peters and Schrader and Anaktuvuk Pass areas.

The dominant well-drained soil of the Alaskan Arctic has been termed arctic brown (Tedrow and Hill, 1955). On the Foothills and Coastal Plain its distribution is limited to perhaps less than $1 \%$ of the land surfaces. For the glaciated valley and frost-rived mountainous terrains which produce better drained soil sites, this distribution increases to at least $10 \%$. The well-drained soils are reported to reflect the northward weakening of the podzolic process (Tedrow et al., 1958). The short, dry, cool, snow-free summers result in a reduction of biological activity and of effective leaching. Most of these well-drained soils have a persistent brown-colored mineral horizon (Table V). In the valleys of the Brooks Range, and particularly in the Okpilak and Anaktuvuk Valleys, a soil with a thin to discontinuous gray $\mathrm{A}_{2}$ horizon was observed in close proximity to the arctic brown soil. Based upon morphological and chemical criteria this soil was considered podzollike.

The data from these studies have already been presented in detail elsewhere (Tedrow and Brown, 1962; Brown, 1962b; and Brown and Tedrow, 1964). In the majority of the arctic brown soils there was no significant increase in free iron oxide below the first mineral horizon. All of the podzol-like soils showed a definite increase in free iron oxide in the $B$ horizon. Free $\mathrm{Mn}$ showed no substantial trend in the arctic brown group of soils but increased with depth in the podzol-like soils. The $\mathrm{pH}$ values of both soils increased with depth; the most acid values were in the range of $\mathrm{pH} 4.5$ to 5.0 in the upper solum to $\mathrm{pH} 5.0$ to 6.0 in the lower solum and $\mathrm{C}$ horizon. Although carbonate deposits are commonly present on the underside of cobbles within the solum, values on the $<2-\mathrm{mm}$ size fraction are at times as low as $\mathrm{pH} 5.5$. Carbon-nitrogen ratios indicated a range of 14 to 20 in the $B$ horizon. No genetic accumulation of organic matter was noted in the $B$ horizons of any of the soils. In the podzol-like soils cation exchange capacity and base saturation decreased with depth. Grain-size analyses indicated a clay content of generally less than $10 \%$, with coarseness increasing at depth. No significant clay weathering was noted in any of the 
soils, although abrupt mineralogical changes were. Radiocarbon analyses of organic matter in the $A$, horizon of a podzol-like soil from the Okpilak Valley showed it to be $175 \$ 75$ years old (Trautman, 1963).

Table V. Description of arctic brown soil

\begin{tabular}{|c|c|c|}
\hline Horizon & Depth $(\mathrm{cm})$ & Description \\
\hline$A_{0}$ & $2-0$ & $\begin{array}{l}\text { Thin, raw organic mat consisting of lichens } \\
\text { and dry mosses; gravels and cobbles common. }\end{array}$ \\
\hline$A_{1}$ & $0-5$ & $\begin{array}{l}\text { Dark reddish brown to black well-decomposed } \\
\text { organic with fines and gravels interspersed, } \\
\text { wavy lower boundary. }\end{array}$ \\
\hline $\mathrm{B}_{21}$ & $5-25$ & $\begin{array}{l}\text { Sandy loam, colors range from strong brown } \\
(7.5 \text { YR } 5 / 6) * \text { to yellowish brown }(10 \text { Y R } 5 / 6) \text {. }\end{array}$ \\
\hline $\mathrm{B}_{22}$ & $25-45$ & $\begin{array}{l}\text { Sandy loam, colors transitional between } B_{21} \\
\text { and C with brown ( } 10 Y R 4 / 3 \text { ) to yellowish } \\
\text { brown ( } 10 \text { Y R } 5 / 4 \text { ) colors common; carbonate } \\
\text { crust:3 present on underside of cobbles; silt } \\
\text { skins common. }\end{array}$ \\
\hline C & below 45 & $\begin{array}{l}\text { Gravelly sandy loam; loose, pale brown } \\
\text { (10YR6/3) to light yellow brown }(2.5 \text { Y } 5 / 4) \text {; } \\
\text { (Pfg. } 3 \text { ). }\end{array}$ \\
\hline
\end{tabular}

Field criteria for the rate and degree of soil formation have been based principally on color development in the solum, thickness of the solum, and presence of the light-colored $A_{2}$ horizon.

Unlike observations by Chandler (1943), Crocker and Dickson (1957), and Leahey (1947), a pedogenic function based solely upon increasing surface age was not substantiated in these longitudinal valley traverses of the Brooks Range. In most instances, variation in parent materials is more important than the time function. A solum of moderate thickness (25 to $35 \mathrm{~cm}$ ) develops even on the young deposits when parent materials are acid and/or rich in iron-bearing minerals. Where, however, the till is charged with calcareous materials, the development of strong brown colors is apparently depressed, with the result that different-aged surfaces yield weakly differentiated soils.

No positive correlation was found between the presence of the podzollike soil and the time function. In the Okpilak River region, this soil occurred most abundantly on granitic glacial deposits of perhaps Itkillik age. In the Anaktuvuk Pass a rea, podzol-like soils were found on acidic glacial deposits which were radiocarbon dated at approximately 2800 to 6300 years old (Porter, 1964). The lithology is considered more important than the time factor in the formation of both arctic brown and podzol-like soils in the northern Brooks Range. Great care should therefore be exercised in attempting to correlate glacial sequences with degree of soil development. 
The distribution of both these well-drained soils, however, is often modified and controlled more by microrelief and vegetation than by lithology and time. Local prominences are subjected to wind abrasion during the snow-free period. This favors the perpetuation of a xeric, barrens vegetation and a discontinuous $A$ horizon, conditions which result in reduced leaching, in free carbonates relatively close to the surface, and in a solum lacking strong color differentiation. Frequently, the wind-blown barrens consist of lichen-covered, pebbly pavement. Arctic brown soils are common on the slightly elevated sites. The occurrence of podzol-like soil is favored by the presence of depressed or protected microrelief and a continuous cover of dwarf heath vegetation. This commonly consists of Betula nana, Salix sp., Vaccinium uliginosum, Vaccinium Vitis-idaea, Ledum decumbens, Arctostaphylos alpina, Dryas octopetala; Empetrum nigrum, Carex sp., and several species of Alectoria, Cladonia, and Cetraria $=\frac{\text { a biota }}{}$ commonly associated with podzol formation. These micro-depressions are completely vegetated, accumulate more snow, and remain moist - a situation that favors more leaching.

The genetic authenticity of the $\mathrm{A}_{2}$ horizon of the podzol-like soil remains a moot problem in northern Alaska. A contemporaneous depositional process, water or eolian, is observed on similar sites on the North Slope of Alaska. The strongest argument against such depositional origins in the Okpilak River area is the absence of organic accumulation or buried surface at the lower boundary of the $\mathrm{A}_{2}$ horizon. It is difficult to postulate the deposition of a gray sandy layer over a brown mineral soil, which would have had to be devoid of previous vegetation.

It is conceivable that the podzol-like soil represents the remains of a once-widespread soil. Paleoclimatic analyses suggest several warmer periods in the time ranges under consideration (Porter, 1964). A moister climate, which would have enhanced the widespread formation of the podzol-like soil, has not, however, been substantiated. Subsequent truncation of the upper horizon by erosion and reduced leaching might account for the present distribution of arctic brown, podzol-like soils, and various intergrades.

Soil instability on these well-drained sites, principally caused by frost action, is not as extensive as it is on saturated soils. Weakly developed forms of circles, nets, steps, and polygons are, however, frequently associated with the arctic brown and podzol-like soils. The radiocarbondated sample of approximately 175 years for the $A_{1}$ horizon of a profile in the Okpilak Valley was associated with a nonsorted step. Formation of this horizon apparently took place in the period covered by the radiocarbon date. As evidenced by buried horizons associated with this frost feature, soil morphology within the soil pit suggested that the gray $\mathrm{A}_{2}$ horizon was present prior to this average date.

Among the chemical processes operating during the development of both the arctic brown and podzol-like soils are increases in acidity, solution of carbonates, and a low-order mobilization and translocation of $\mathrm{Fe}$ and $\mathrm{Mn}$ in the surface horizon of certain soils. Earlier it was shown that small quantities of $\mathrm{Fe}, \mathrm{Al}$ and $\mathrm{Mn}$ were translocated within the arctic brown soil (Drew and Tedrow, 1957). Mikhailov (1961) questioned that this represented an embryonic podzolization process. For at least some of 
these soils, it is evident that a process of translocation is in effect. It does appear, however, that the soil-forming processes present in these soils of the Brooks Range are somewhat similar to those processes operating in other low rainfall areas of northwestern North America (Kubota and Whittig, 1960; Leahey, 1947; Pawluk, 1960; Rieger and Juve, 1961; Wright et al., 1959; Day and Rice, 1964).

The weakening of the soil-forming processos with increasing altitude was suggested in the study area (Tedrow and Brown, 1962) (Fig. 70). Observations were made on the well-drained soils across vertical transects ranging from altitudes of 600 to $1700 \mathrm{~m}$. Soil color and depth of solum were again the principal soil criteria utilized for determining soil development. Although the glacial deposits at lower altitudes probably represented considerably younger soil parent material than the unglaciated, higher mountainous landscapes, for all soils studied elapsed time was considered sufficient to reflect the morphology of a mature profile. With increased elevation, vegetative cover changes from a completely closed to broken mat of predominantly vascular plants to open cover with a predominance of

\section{IDEALIZED SOIL PROFILES}
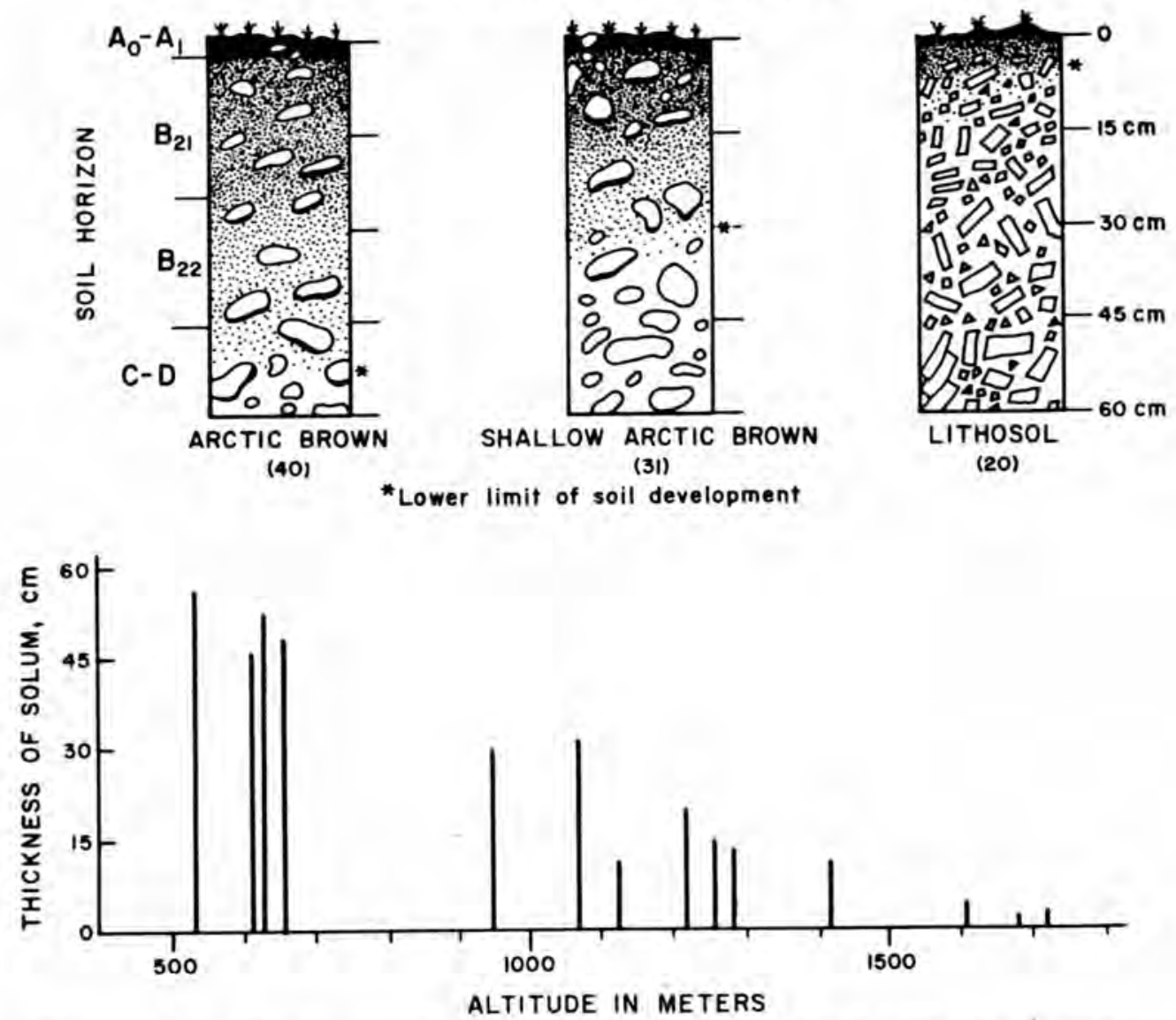

Figure 70, Decreasing depth of soil development with increasing altitude in the Brooks Range (Tedrow and Brown, 1962). 
lichens and mosses. On the gravelly glacial and stream deposits of the valleys the arctic brown soils have a solum thickness of about $50 \mathrm{~cm}$. On the stable bedrock positions at 900 to $1200 \mathrm{~m}$ there is a noticeable suppression of the soil-forming potential. At these altitudes the shallow arctic brown solum has a thickness of about $30 \mathrm{~cm}$, and between 1200 and $1500 \mathrm{~m}$ a maximum of $20 \mathrm{~cm}$. Finally, at $1700 \mathrm{~m}$ or so, the upper limit of stable soil sites, the soil consists of only 2 to $3 \mathrm{~cm}$ of discontinuous organic matter with virtually no characteristic brown soil color in the mineral material. In addition to the decreased depth of solum with inc:easing altitude, the parent material is looser and coarser and the $A_{1}$ horizon becomes less important with the B horizon dominant.

From these observations the general conclusion was drawn that the thickness of the solum as indicated basically by soil color is a function of climate or of decreased temperature with altitudes. Even though the soil sites at higher altitudes may have been exposed to weathering for considerably greater time than those on the younger glaciated terrain, soil formation has not penetrated to the depths observed at lower altitudes. However, it should be mentioned that the secondary deposits such as moraines yield a deeper solum faster than a consolidated bedrock parent material, regardless of altitude.

In conclusion, it was observed that in the valleys of the northern Brooks Range and southern Foothills different-aged surfaces fail to yield pronounced chronosequences of soil development (largely because of differences in parent materials). In this area, frequently within a short distance of the northern tree-line, two distinct, well drained soils exist side by side. In the valleys the arctic brown predominates, with the podzollike soil present under certain optimum conditions of vegetation, microrelief, and parent materials. The present regional climate apparently favors the widespread distribution of the arctic brown. With increasing altitude the thickness of the well-drained solum decreases, a function of reduced temperatures and, in part, less physically weatherable parent materials.

An organic terrain

In the Okpilak River Valley, a combination of organic soils and patterned ground features constitutes a limited area of organic terrain (Brown, 1962a, 1962b). The presence of these conditions warranted further investigation, since organic soils have not been investigated as extensively as the well-drained and tundra soils in northern Alaska. Icewedge polygons in various forms of development and degradation dominate the tussock-covered tundra landscape. The organic soils vary in composition and structure and include moss peats, sod peats, and secondary depositional accumulations of organic materials (Fig. 64 to 68). The moss peat occupies the flat tops of the ice-wedge polygons. The depth of seasonal thaw is limited to $25-30 \mathrm{~cm}$. As the width of the ice wedge trough increases, more and more of the trough area is occupied by a wetter sodlike peat. Water commonly stands or flows through these troughs. The flat, ice-wedge polygon eventually develops into high-centered polygons and peaty mounds which result in a mosaic of marsh and moss peats (Fig. $71-73)$. The moss peat becomes a dry peat on these high-centered polygons with corresponding decrease in depth of thaw (Fig. 67). 


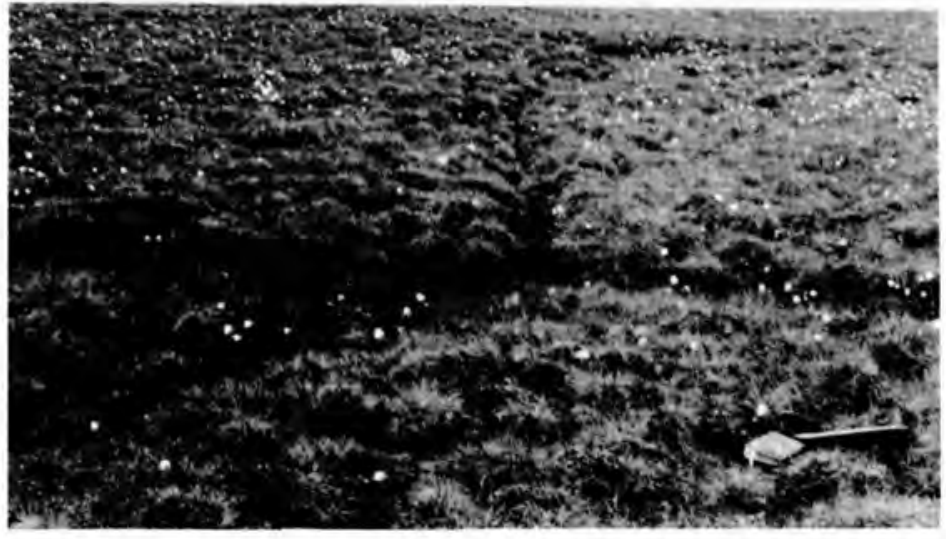

Figure 71 . Weakly developed ice-wedge polygons with small cottongrass tussocks (moss peat).

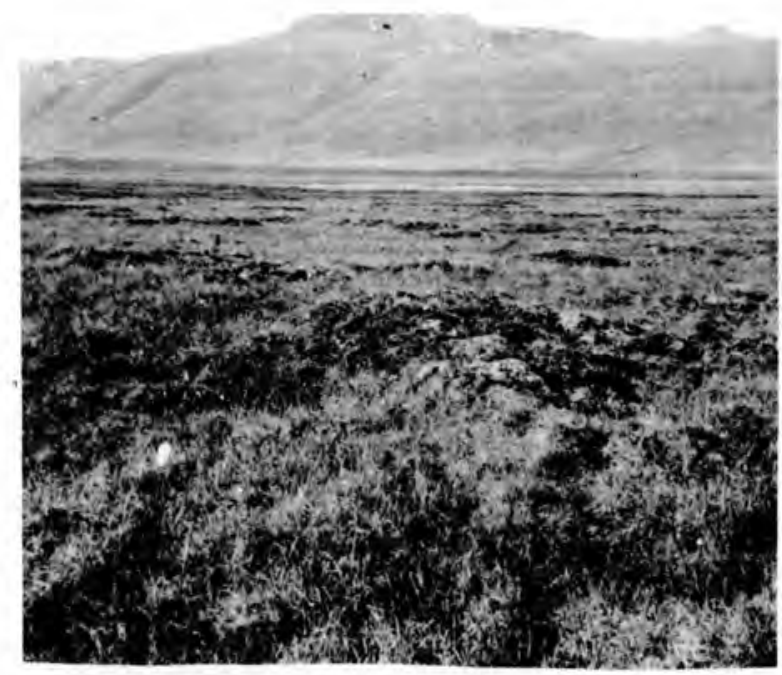

Figure 73. Area of peaty mounds which possibly represents final degradation of polygonal area.

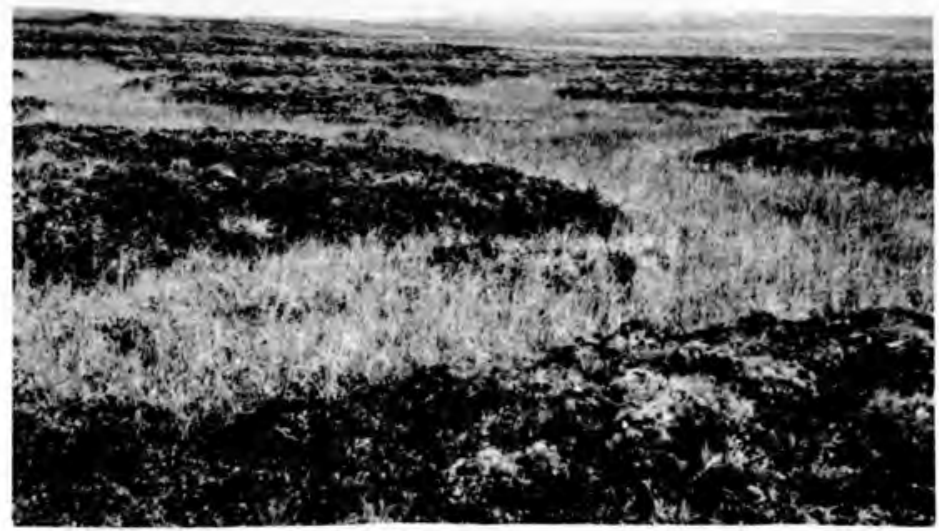

Figure 72. Mosaic of polygon tops (dry peat) and troughs (sod peat).

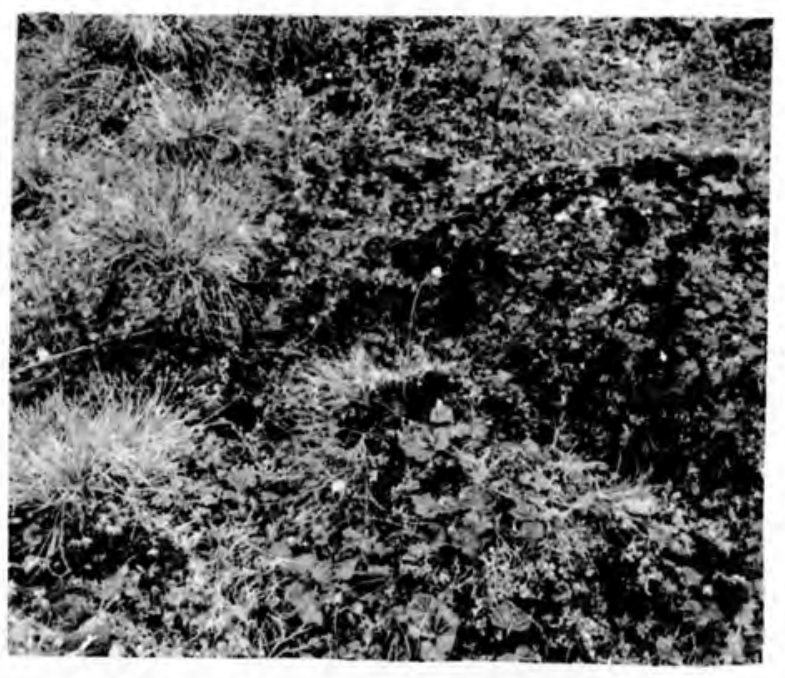

Figure 74. Characteristic moss-peat vegetation with both tussocks and hummocks. 
The modal site for the occurrence of the organic terrain is on the flat valley floor adjacent to the east side of West Okpilak Lake. Organic soils also ascend the gentle valley slopes and are observed on the uplands but are not associated with the ice-wedge polygon sequence.

The vegetation of the moss peat soil is a dwarf shrub-heath type with various sizes of cottongrass tussocks (Fig. 74). This includes Eriophorum vaginatum, Ledum palustre decumbens; Vaccinium Vitis-idaea, Vaccinium uliginosum, Empetrum nigrum, Betula sp. Arctostaphylos alpina, several Carices, and Rubus chamaemorus. Lichens include Cetraria cucullata, Cetraria nivalis, Alectoria (black), Thamniola vermicularis, and Cladonia sp. Sphagnum fuscum is the dominant moss with Dicranum sp. and Polytrichum sp. present. The sphagnum species form the predominantly mossy substratum, although the finely divided layers may also consist of the remains of sedges and grasses. Tussock development is not as pronounced on the very wet, mossy sites as on the drier peats. The presence of Rubus chamaemorus is characteristic of this organic soil.

Ten organic samples were collected from five shallow profiles and one from a frost ooze of the type $\mathrm{H}_{\mathrm{S}}$ (Fig. 40). Six of the samples are from three profiles within a polygon $22 \mathrm{~m}$ in diameter. Two samples were from a profile situated on a high-centered peaty polygon located approximately $50 \mathrm{~m}$ south of this sampled polygon. A wet meadow tundra soil and an ooze, north of the main sample area, are included. These samples are described in Table VI:

For purposes of discussion and reporting of the results the samples are grouped according to physical appearance: the well-preserved, spongy moss samples (No. 31, 33, 34, 35, 38, 45) and the finely divided materials (No. 32, $36,37,46)$. Sample 39 is a mineral horizon of the meadow tundra soil.

The data presented in Table VII indicate the acidic nature of moss peat and are typical of highmoor peats. The large loss-on-ignition values a re characteristic of the mossy vegetation which constitutes the major part of the organic soil. The high ash contents are the result of mineral additions in the form of waterborne and airborne silts and sands. The cation exchange capacities agree with values for mosses and dry peats from other areas as do the nitrogen and phosphorus levels.

In regions of perennially frozen ground, the frost table impedes drainage. Water remains ponded in surface depressions and in polygon trenches. Under these conditions, ice-wedge polygons and moss peat soils may develop on the subdued relief of the valley floor. As the organic surface thickens, the insulating effect of the peat causes a reduction in the depth of the seasonally thawed soil. At first, the profile consists of a wet mineral substratum and a thin cover of moss and tussocks. This is represented by the wet meadow tundra profile 4 (Table VI). Where conditions are favorable for moss formation, the thawed zone soon becomes entirely organic as additions of organic matter are made by the moss vegetation. Decomposition is slow in the cold anaerobic environment. The formation of peat assiciated with perennially frozen ground differs from the development of highmoor peats in regions of unfrozen ground. The modal peat of the flat terrain does not develop solely as a result of moisture from atmospheric precipitation, although $\mathrm{P} / \mathrm{E}$ values are high with much fog and high humidity. Ponding is enhanced by the raised edges of polygons. 
Table VI. Moss peat profiles and related soils

\begin{tabular}{cccl}
\hline Profile & Sample & Depth $(\mathrm{cm})$ & \multicolumn{1}{c}{ Description } \\
\hline 1 & $0-10$ & $\begin{array}{l}\text { Dark brown }(7.5 Y R 4 / 5), \text { well-preserved } \\
\text { moist, loose moss and shreds of cotton- } \\
\text { grass tus sock; consistency grades into } \\
\text { more matted moss at } 8 \text { to } 10 \mathrm{~cm} . \\
\text { Principally Sphagnum. }\end{array}$ \\
& & $\begin{array}{l}\text { Wet, dark reddish-brown to black } \\
\text { (5YR3/3 to 5YR3/1), finely divided } \\
\text { organic material, little recognizable } \\
\text { plant remains, darker at frost table } \\
(\text { Pfg. } 30 \mathrm{~cm}) .\end{array}$ \\
\hline
\end{tabular}

$2 \quad 33 \quad 0-8 \quad$ Black, loose, well-preserved moss peat with woody twigs and roots. Sphagnum and Dicranum.

34 8-30 Black, well-preserved, wet mossy peat and organic shreds; somewhat more compact with depth (Pfg. $30 \mathrm{~cm}$ ).

\begin{tabular}{|c|c|c|c|}
\hline \multirow[t]{2}{*}{3} & 35 & $0-15$ & $\begin{array}{l}\text { Dark brown to black, well-preserved } \\
\text { moss peat, on raised edge of polygons } \\
\text { with small tussocks. Sphagnum } \\
\text { dominant, Dicranum present. }\end{array}$ \\
\hline & 36 & $15-30$ & $\begin{array}{l}\text { Brown }(7.5 Y \mathrm{R} 5 / 2) \text {, finely divided } \\
\text { organic material with coarse sands } \\
\text { and cobbles embedded in the organic } \\
\text { matrix (Pfg. } 30 \mathrm{~cm}) .\end{array}$ \\
\hline- & 37 & $5-25$ & $\begin{array}{l}\text { Dark brown, organic silt ooze from } \\
\text { moderately polygonized moss peat area; } \\
\text { few rounded cobbles embedded. }\end{array}$ \\
\hline \multirow[t]{2}{*}{4} & 38 & $0-10$ & $\begin{array}{l}\text { Brown moss mat between cottongrass } \\
\text { tussocks. Dicranum and liverwort } \\
\text { present. }\end{array}$ \\
\hline & 39 & $10-32$ & $\begin{array}{l}\text { Gray, mottled silt loam with slight crumb } \\
\text { structure immediately below the mat (wet } \\
\text { meadow tundra) (Pfg. } 32 \mathrm{~cm} \text { ). }\end{array}$ \\
\hline \multirow[t]{2}{*}{5} & 45 & $2-8$ & $\begin{array}{l}\text { Dark reddish-brown, coarsely fibrous } \\
\text { woody peat from high-centered peaty } \\
\text { polygon. Dicranum and Polytrichum. }\end{array}$ \\
\hline & 46 & $10-25$ & $\begin{array}{l}\text { Dark brown, very finely divided, silty } \\
\text { organic materials with some coarse } \\
\text { sands (Pfg. } 25 \mathrm{~cm} \text { ). }\end{array}$ \\
\hline
\end{tabular}


Table VII. Partial chemical data from a moss peat and related soils.

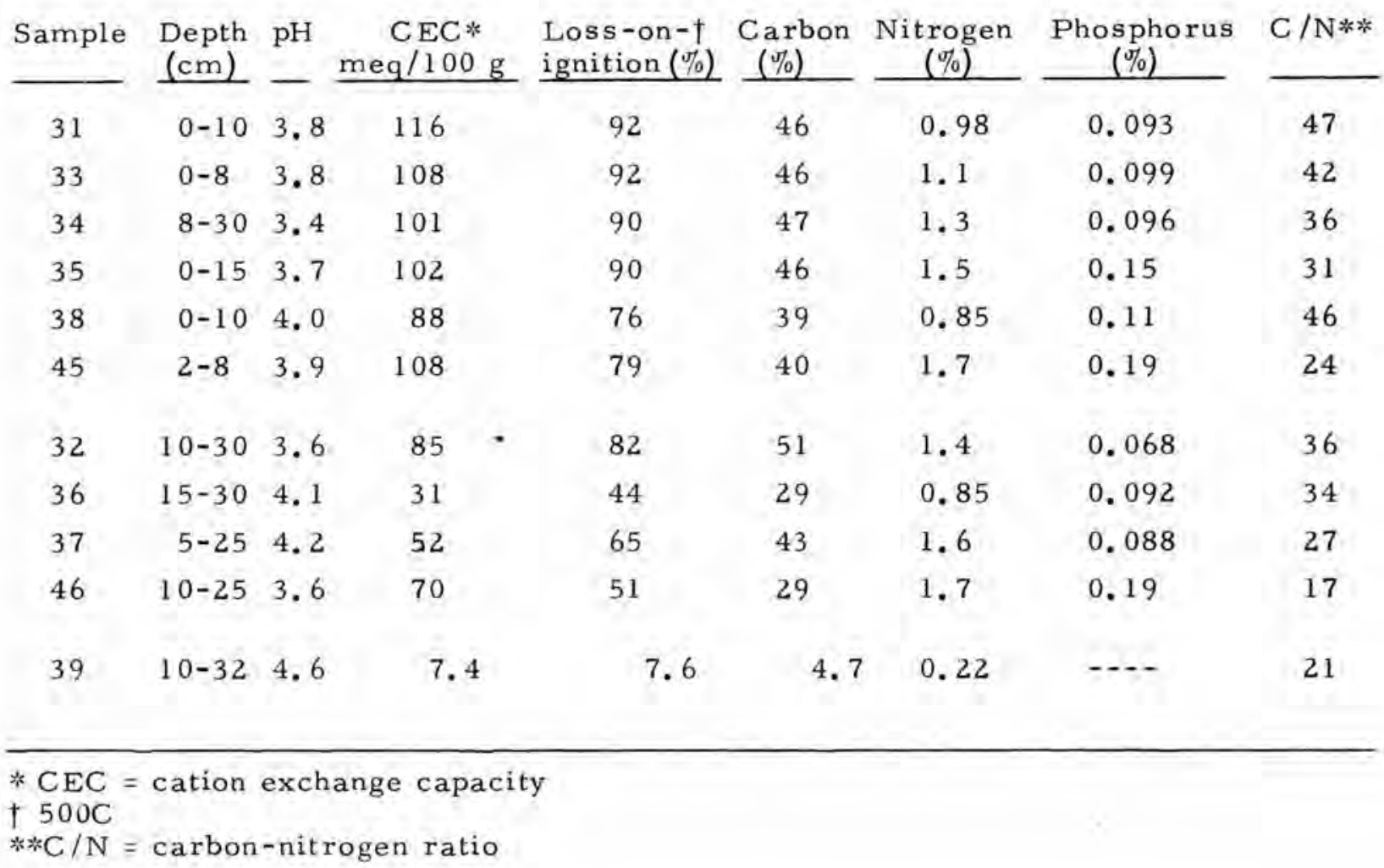

A source of nutrients is probably locally supplied to the peat through frost churning. Mineral and organic materials from the lower profile are circulated through the peat onto the surface as oozes. Cobbles imbedded in the subsurface organic layers are further evidence of upward movements due to frost activity. Additional nutrients are supplied by windborne silts and the breakdown of organic constituents as a result of mineralization. The frost churning is partly responsible for the fine division of organic matter.

The diagenesis of the moss peat soil is further demonstrated by the growth and the eventual partial thaw of ice wedges and massive ice lenses. As ice wedges grow, the volume of the total substratum increases. This results in the slight raising of portions of the developing polygon, particularly adjacent to the wedges. However, the polygon edges do not seem to be raised as much in peaty soils as in the wet mineral soils. This may be a result of the greater compressibility of the peat. Primary and secondary troughs of polygons develop on the tussock-covered surfaces. Ice wedges (Fig. 17) increase in size with time. The troughs broaden and become filled 
with water and a bog vegetation develops. The flow of water enhances the deepening of the troughs by increasing the melting of the initial ice wedges. Slump occurs along the edges of the polygons, and exposes new ice wedges and lenses. This deepening and broadening of the troughs eventually leads to the formation of a mosaic of high-centered peaty polygons. The tussockcovered, high-centered polygon is considerably drier than the weakly developed, low-centered polygon. Peat accumulation in the former is probably reduced. In a further stage in the degradation of the high-centered peaty polygon, peaty mounds may develop amidst a sod-like bog. These polygonal forms may therefore represent a sequence of events from weakly developed ice-wedge polygons to high-centered peaty polygons to degraded peaty mounds (Fig. 71-73).

\section{LITERATURE CITED}

Britton, M.E. (1957) Vegetation of the arctic tundra, Oregon State College, Corvallis, Oregon, Biology Colloquium, Proceedings, p. 26-61.

Brown, J. (1962a) Organic terrain from a glaciated valley, northern Alaska, Proceedings, 13th Alaskan Science Conference, p. 159-160.

(1962b) Soils of the northern Brooks Range, Alaska, Ph. D. Thesis, Rutgers University, New Brunswick, New Jersey.

and Tedrow, J.C.F. (1964) Soils of the northern Brooks Range, Alaska: 4 Well-drained soils of the glaciated valleys, Soil Science, vol. 97, p. 187-195.

Cantlon, J.E. (1961) Plant cover in relation to macro-, meso-, and microrelief, Final Report, AINA, Grants ONR-208 and 212 (unpubl.)

Chandler, R, F., Jr, (1943) The time required for podzol profile formation as evidenced by the Mendenhall Glacier deposits near Juneau, Alaska, Soil Science Society of America Proceedings (1942), vol. 7, p. 454-459.

Conover, J.H. (1960) Macro- and microclimatology of the Arctic Slope of Alaska, Quartermaster Research and Engineering Center, Natick, Massachusetts, Technical Report EP 139.

Corte, A.E. (1959) Experimental formation of sorted patterns in gravel overlying a melting ice surface, U.S. Army Snow Ice and Permafrost Research Establishment, Research Report 55.

(1963) Particle sorting by repeated freezing and thawing,

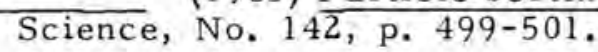

Crocker, R. L. and Major, J. (1955) Soil development in relation to vegetation and surface age at Glacier Bay, Alaska, Journal of Ecology, vol. 43, p. 427-448.

and Dickson, B.A. (1957) Soil development on the recessional moraines of the Herbert and Mendenhall Glaciers of southeastern Alaska, Journal of Ecology, vol. 45, p. 169-185.

Day, J.H. and Rice, H.M. (1964) The characteristics of some permafrost soils in the Mackenzie valley, N.W. T., Arctic, vol. 17, p. $222-236$. 


\section{LITERATURE CITED (Cont'd)}

Detterman, R. L.; Bowsher, A. L.; and Dutro, J. T. (1958) Glaciation on the Arctic Slope of the Brooks Range, northern Alaska, Arctic, vol. 11, p. 43-61.

Douglas, L. A. (1961) A pedologic study of tundra soils from northern Alaska, Ph. D. Thesis, Rutgers University, New Brunswick, New Jersey.

and Tedrow, J.C F. (1961) Tundra soils of arctic Alaska, Proceedings, 7 th International Soil Science Congress Commission V, vol. IV, p. 291-304.

Drew, J. V. (1957) A pedologic study of Arctic Coastal Plain soils near Point Barrow, Alaska, Ph. D. Thesis, Rutgers University, New Brunswick, New Jersey.

and Tedrow, J.C.F. (1957) Pedology of an arctic brown profile near Point Barrow, Alaska, Soil Science Society of America, Proceedings, vol. 21, p. 336-339.

(1962) Arctic soil classification anc: patterned ground, Arctic, vol. 15, p. 109-116.

Hill, D.E. and Tedrow, J.C.F. (1961) Weathering and soil formation in the arctic environment, American Journal of Science, vol. 259, p. 84-101.

Holmes, G. W. and Lewis, C. R. (1965) Quaternary geology of the Mount Chamberlin Area, Brooks Range, Alaska, U.S. Geological Survey Bulletin 1201-B, 32 p.

Keeler, C.M. (1959) Notes on the geology of the McCall Valley area, Arctic, vol. 12, p. 87-97.

Kubota, J. and Whittig, L. Ir. (1960) Podzols in the vicinity of the Necchina and Tazlina Glaciers, Alaska, Soil Science Society of America, Proceedings, vol. 24, p. 133-136.

Kunkle, G. R. (1958) Multiple glaciation in the Jago River area, northeastern Alaska, M.S. Thesis, University of Michigan, Ann Arbor, Michigan.

Leahey, A. (1947) Characteristics of soils adjacent to the MacKenzie River in the Northwest Territories of Canada, Soil Science Society of America, Proceedings, vol. 12, p. 458-461.

Leffingwell, E. deK. (1919) The Canning River region, northern Alaska, U.S. Geological Survey Professional Paper 109.

MacNamara, E.E. (1964) Soils of the Howard Pass area, northern Alaska, Special Report to Arctic Institute of North America (Rutgers University, New Brunswick, New Jersey).

Malcolm, W. McL. II (1959) The genus Carex of the Arctic Slope of Alaska, an annotated species list and key, M.S. Thesis, Michigan State University, E. Lansing, Michigan.

Mikhailov, I.S. (1961) Soil studies in northern Alaska, Soviet Soil Science, no. 2, p. 209-214. 


\section{LITERATURE CITED (Cont'd)}

Nikiforoff, C.C. Soils of Eurasian Arctic, Encyclopedia Arctica, vol. VI, Plant Sciences, Regional No. 13 (unpubl.).

Pawluk, S. (1960) Some podzol soils of Alberta, Canadian Journal of Soil Science, vol. 40, p. 1-14.

Porter, S.C. (1964) Late Pleistocene glacial chronology of northcentral Brooks Range, Alaska, American Journal of Science, vol. 262 , p. $446-460$.

Rieger, S, and Juve, R. L. (1961) Soil development in recent loess in the Matanuska Valley, Alaska, Soil Science Society of America, Proceedings, vol. 25, p. 243-248.

Sable, E. G. (1959) Preliminary report on sedimentary and metamorphic rocks in part of the Romanzof Mountains, Brooks Range, N. E. Alaska, M.S. Thesis, University of Michigan, Ann Arbor, Michigan.

(1961) Recent recession and thinning of Okpilak Glacier, northeastern Alaska, Arctic, vol. 14, p. 176-187.

(1965) Geology of the Romanzof Mountains, Brooks Range, nortbeastern Alaska, Ph. D. Thesis, University of Michigan, Ann Arbor, Michigan.

Sharp, R. P. (1942) Soil structures in the St. Elias Range, Yukon Territory, Journal of Geomorphology, vol. 5, p. 274-287.

Smith, J. (1956) Some moving soils in Spitsbergen, Journal of Soil Science, vol. 7, p. 10-21.

Spetzman, L.A. (1959) Vegetation of the Arctic Slope of Alaska, U.S. Geological Survey Professional Paper 302B.

Springer, M.E. (1958) Desert pavement and vesicular layer of some soils of the desert of the Lahonthan Basin, Nevada, Soil Science Society of America, Proceedings, vol. 22, p. 63-66.

Tedrow, J.C.F. and Brown, J. (1962) Soils of the Brooks Range, northern Alaska. I. Weakening of soil forming potential at high arctic altitudes, Soil Science, vol. 93, p. 254-261.

(1965) Soils of arctic Alaska, Paper

presented at VII International Congress INQUA, Boulder, Colorado.

and Cantlon, T. E. (1958) Concepts of soil formation and classification in arctic regions, Arctic, vol. 11, p. 166-179.

; Drew, J.V.; Hill, D.E.; and Douglas, L.A. (1958)

Major genetic soils of the Arctic Slope of Alaska, Journal of Soil Science, vol. 9, p. 33-45.

and Hill, D. E. (1954) Soil characteristics of the

Arctic Slope of Alaska - - A pedologic report, Boston University Physical Research Laboratory (unpubl. ms.).

vol. 80, p. $265-275$.

(1955) Arctic brown soil, Soil Science,

Trautman, M.A. (1963) Isotopes, Inc. radiocarbon measurements III, Radiocarbon, vol. 5 , p. 62-81. 


\section{LITERATURE CITED (Cont'd)}

Ugolini, F.C. and Tedrow, J.C.F. (1963) Soils of the Brooks Range, Alaska: 3. Rendzina of the Arctic, Soil Science, vol. 96, p. 121-127.

U.S. Weather Bureau (1957-1961) Climatological data, Alaska. Annual Summaries, U.S. Department of Commerce.

Washburn, A.L. (1956) Classification of patterned ground and review of suggested origins, Geological Society of America Bulletin, vol, 67, p. 823-866.

Whittington, C. L. and Sable, E. G. (1948) Preliminary report on the geology of the Sadlerochit River area, Alaska, U.S. Geological Survey, PR 20.

Wright, J.R.; Leahey, A.; and Rice, H.M. (1959) Chemical, morphological, and mineralogical characteristics of a chronosequence of soils in alluvial deposits in the Northwest Territories, Canadian Journal of Soil Science, vol. 39, p. 32-43. 


\section{Unclassified}

Security Classification

DOCUMENT CONTROL DATA - R\&D

(Security cleseiffeation of title, body of abatract and indexine annotation muat be entered when the overall report is classified) ORIGINATING ACTIVITY (Corporato author)

U.S. Army Cold Regions Research and

Engineering Laboratory, Hanover, N.H. Unclassified

2b. GROUP

3. REPORT TITLE

SOILS OF THE OKPILAK RIVER REGION, ALASKA

4. DESCRIPTIVE NOTES (Type of report and incluaive dates)

Research Report

5. AUTHOR(S) (Laat name. first name, initial)

Brown, Jerry

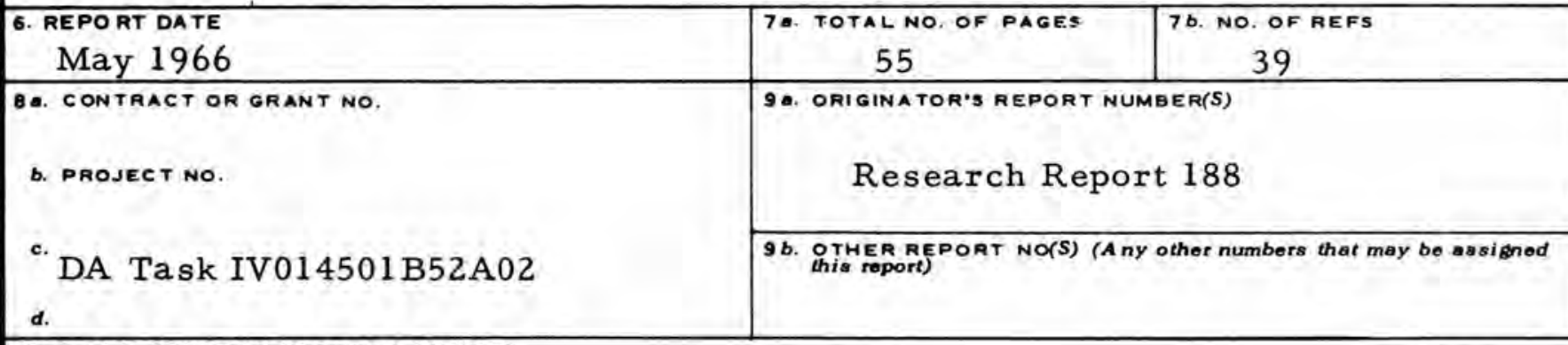

10. AVAILABILITY/LIMITATION NOTICES

Distribution of this document is unlimited

11. SUPPL EMENTARY NOTES

12. SPONSORING MILITARY ACTIVITY

U.S. Army Cold Regions Research and

Engineering Laboratory

13. ABSTRACT

Concepts of Arctic pedology are applied to the glaciated and unglaciated terrains in the vicinity of the Okpilak River, northeastern Alaska. Two types of frost action in Arctic soils are considered: (1) the surficial configurations or patterned ground, and (2) the morphological characteristics of the seasonally thawed soil and the upper zone of perennially frozen ground. About 55 types of soil conditions and surface features are described and mapped in an area encompassing both the northern Brooks Range and the southern Foothill Provinces. These include the genetic soils of Arctic Alaska, numerous soil conditions, and many of the common sorted and nonsorted circles, nets, polygons, steps, and stripes: In the glaciated and periglacial areas, sorted features predominate on the coarse-textured substrata. The Arctic brown soils are distributed on the well-drained sites along valley traverses and across mountain gradients. On a sequence of valley moraines, acid parent material is considered more important than time and mesoenvironments in influencing the depth and development of the characteristic brown solum. Weakening of the soil-forming processes with increasing altitude is suggested in the mountains. In the valleys, a podzol-like soil is observed in close proximity to the Arctic brown soils and in association with acid parent materials, dwarf birch-heath vegetation and protected microrelief positions. A combination of peaty soils associated with icewedge polygons constitutes an organic terrain. The developments of these soils under the Arctic environment are discussed. 


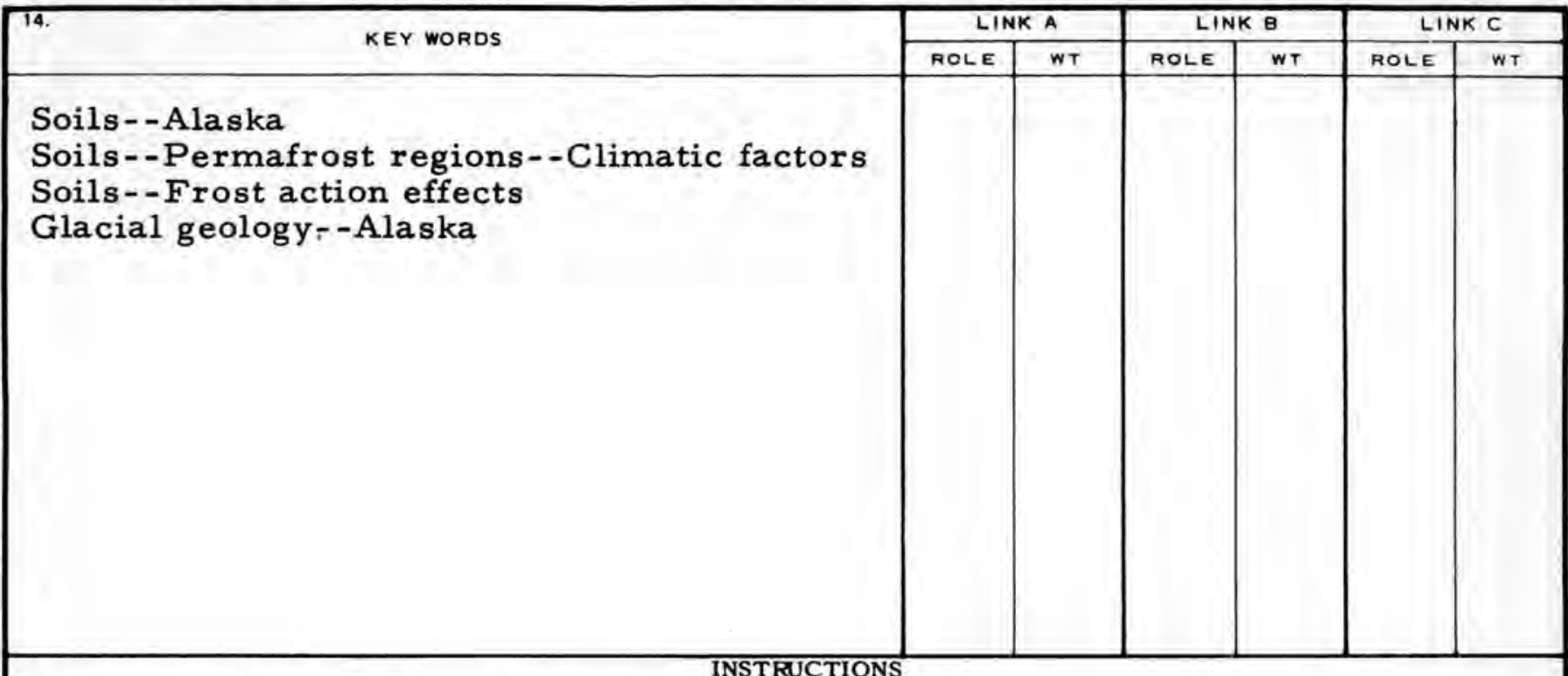

1. ORIGINATING ACTIVITY: Enter the name and address of the contractor, subcontractor, grantee, Department of Defense activity or other organization (corporate author) issuing the report.

2a. REPORT SECURTY CLASSIFICATION: Enter the overall security classification of the report. Indicate whether "Restricted Data" is included. Marking is to be in accord ance with appropriate security regulations.

2b. GROUP: Automatic downgrading is specified in DoD Directive 5200.10 and Armed Forces Industrial Manual. Enter the group number. Also, when applicable, show that optional markings have been us ed for Group 3 and Group 4 as authorized.

3. REPORT TITLE: Enter the complete report title in alt capital letters. Titles in all cases should be unclassified. If a meaningful title cannot be selected without classification, show title classification in all capitals in parenthesis immediately following the title.

4. DESCRIPTIVE NOTES: If appropriate, enter the type of report, e.g., interim, progress, summary, annual, or final.

Give the inclusive dates when a specific reporting period is covered.

5. AUTHOR(S): Enter the name(s) of author(s) as shown on or in the report. Enter last name, first name; middle initial. If military, show rank and branch of service. The name of the principal author is an absolute minimum requirement.

6. REPORT DATE: Enter the date of the report as day, month, year; or month, year. If more than one date appears on the report, use date of publication.

7a. TOTAL NUMBER OF PAGES: The total page count should follow normal pagination procedures, i, e., enter the number of pages containing information.

7b. NUMBER OF REFERENCES. Enter the total number of references cited in the report.

8a. CONTRACT OR GRANT NUMBER: If appropriate, enter the applicable number of the contract or grant under which the report was written.

$8 b, 8 c, 8$ 8d. PROJECT NUMBER: Enter the appropriate military department identification, such as project number, subproject number, system numbers, task number, etc.

9a. ORIGINATOR'S REPORT NUMBER(S): Enter the official report number by which the document will be ident ified and controlled by the originating activity. This number must be unique to this report.

9b. OTHER REPORT NUMBER(S): If the report has been assigned any other report numbers (either by the originator or by the sponsor), also enter this number(s).
10. AVAIL ABILITY/LIMITATION NOTICES: Enter any limitations on further dissemination of the report, other than those imposed by security classification, using standard statements such as:

(1) "Qualified requesters may obtain copies of this report from DDC."

(2) "Foreign announcement and dissemination of this report by DDC is not authorized."

(3) "U. S. Government agencies may obtain copies of this report directly from DDC. Other qualified DDC users shall request through

(4) "U. S. military agencies may obtain copies of this report directly from DDC. Other qualified users shall request through

(5) "All distribution of this report is controlled Qualified DDC users shall request through ,

If the report has been furnished to the Office of Technical Services, Department of Commerce, for sale to the public, indicate this fact and enter the price, if known.

11. SUPPLEMENTARY NOTES: Use for additional explanatory notes.

12. SPONSORING MILITARY ACTIVITY: Enter the name of the departmental project office or laboratory sponsoring (pay ing for) the research and development. Include address.

13. ABSTRACT $t$ : Enter an abstract giving a brief and factual summary of the document indicative of the report, even though it may also appear elsewhere in the body of the technical report. If additional space is required, a continuation sheet shall be attached.

It is highly desirable that the abstract of classified reports be unclassified. Each paragraph of the abstract shall end with an indication of the military security classification of the information in the paragraph, represented as (TS), (S), (C), or $(U)$.

There is no limitation on the length of the abstract. However, the suggested length is from 150 to 225 words.

14. KEY WORDS: Key words are technically meaningful terms or short phrases that characterize a report and may be used as index entries for cataloging the report. Key words must be selected so that no security classification is required. Idenfiers, such as equipment model designation, trade name, military project code name, geographic location, may be used as key words but will be followed by an indication of technical context. The assignment of links, rules, and weights is optional 